\title{
Human cytomegalovirus in the vascular tree and other organsystems
}

Citation for published version (APA):

Hendrix, M. G. R. (1998). Human cytomegalovirus in the vascular tree and other organsystems. [Doctoral Thesis, Maastricht University]. Universiteit Maastricht. https://doi.org/10.26481/dis.19981202mh

Document status and date:

Published: 01/01/1998

DOI:

10.26481/dis.19981202mh

Document Version:

Publisher's PDF, also known as Version of record

\section{Please check the document version of this publication:}

- A submitted manuscript is the version of the article upon submission and before peer-review. There can be important differences between the submitted version and the official published version of record.

People interested in the research are advised to contact the author for the final version of the publication, or visit the DOI to the publisher's website.

- The final author version and the galley proof are versions of the publication after peer review.

- The final published version features the final layout of the paper including the volume, issue and page numbers.

Link to publication

\footnotetext{
General rights rights.

- You may freely distribute the URL identifying the publication in the public portal. please follow below link for the End User Agreement:

www.umlib.nl/taverne-license

Take down policy

If you believe that this document breaches copyright please contact us at:

repository@maastrichtuniversity.nl

providing details and we will investigate your claim.
}

Copyright and moral rights for the publications made accessible in the public portal are retained by the authors and/or other copyright owners and it is a condition of accessing publications that users recognise and abide by the legal requirements associated with these

- Users may download and print one copy of any publication from the public portal for the purpose of private study or research.

- You may not further distribute the material or use it for any profit-making activity or commercial gain

If the publication is distributed under the terms of Article $25 \mathrm{fa}$ of the Dutch Copyright Act, indicated by the "Taverne" license above, 
Human Cytomegalovirus in the vascular tree and other organsystems 
1998, M.G.R. Hendrix, Enschede, The Netherlands

\section{IISBN 90-9012216-8}

Printing: FEBODRUK BV offset drukkerij, Enschede.

The publication of this thesis was financially supported by by Laboratorium microbiologie Twente Achterhoek, and the Medisch Spectrum Twente. 


\section{Human Cytomegalovirus in the Vascular}

\section{tree and other Organsystems}

\section{Proefschrift}

ter verkrijging van de graad van doctor

aan de Universiteit Maastricht,

op gezag van de Rector Magnificus,

Prof. Dr. A.C. Nieuwenhuijzen

volgens het besluit van het College van Dekanen,

in het openbaar te verdedigen

op woensdag 2 december 1998 om 14.00 uur

\section{Door}

Matheus Gerardus Ronald Hendrix

Geboren te Maastricht op 28 november 1958 


\section{Promotor:}

Prot. Dr. C.A. Bruggeman

\section{Beoordelingscommissle:}

Prof. Dr. P.J.E.H.M. Kitslaar (voorzitter)

Prof. Dr. M.J.A.P. Daemen

Prof. Dr. F.C.S. Ramaekers

Prof. Dr. Teuchy (LUC Diepenbeek, Belgié) 


\section{aan mijn ouders, aan Esther, aan Elke en Jorn}





\section{Contents}

List of abbreviations

Chapter 1 Introduction. Aims of the study

Chapter 2 General introduction

Chapter 3 The presence of cytomegalovirus nucleic acids in arterial walls of atherosclerotic and nonatherosclerotic patients

Chapter 4 High prevalence of latently present cytomegalovirus in arterial walls of patients suffering from grade III atherosclerosis

Chapter 5 Cytomegalovirus nucleic acid distribution within the human vascular tree

Chapter 6 Widespread presence of cytomegalovirus DNA in tissues of previously healthy trauma victims

Chapter 7 Detection and sequence analysis of the major immediate early and PP150 gene of latent humam cytomegalovirus in spleen, liver and kidney tissues of trauma victims

Chapter 8 General discussion

Samenvatting

Curriculum vitae

Nawoord 


\section{List of Abbreviations}

$\begin{array}{ll}\text { BH-probe } & \text { BamH1-Hindll-probe } \\ \text { BSA } & \text { Bowine serum albumin } \\ \text { CPE } & \text { Cytopathologic effect } \\ \text { CMV } & \text { Cytomegalovirus } \\ \text { ES-fragment } & \text { EcoR1-Sall-fragment } \\ \text { E-genes } & \text { Early-genes } \\ \text { ES-probe } & \text { EcoR1-Sall-probe } \\ \text { HCMV } & \text { Human cytomegalovirus } \\ \text { HEF } & \text { Human embryonic fibroblasts } \\ \text { HGE } & \text { Human genomic equivalents } \\ \text { HSV } & \text { Herpes simplex virus } \\ \text { H\&E } & \text { Hemotoxylin and eosin } \\ \text { IEA } & \text { Immediate early antigen } \\ \text { L-genes } & \text { Late genes } \\ \text { MCAB's } & \text { Monoclonal antibodies } \\ \text { MCMV } & \text { Mouse cytomegalovirus } \\ \text { MDV } & \text { Marek's disease virus } \\ \text { PBS } & \text { Phospate-buffered-saline } \\ \text { PCR } & \text { Polymerase chain reaction } \\ \text { RCMV } & \text { Rat cytomegalovirus } \\ \text { VGE } & \text { Viral genomic equivalents }\end{array}$




\title{
CHAPTER 1
}

\section{Introduction. Aims of the study}

\author{
1. Introduction \\ 2. Aims of the study \\ 3. Outline of the study \\ 4. References
}




\section{Introduction}

Infections with human cytomegalowirus (HCMV) are widespread and the prevalence of these infections based on serological studies ranges from 40 to $90 \%$ (1). In immunocompetent individuals primary HCMV infection usually passes unnoticed and only a minority of individuals will develop a mononucleosis-like syndrome (2, 3). Primary infection can be followed by a prolonged period of active HCMV replication characterized by virus shedding from many body sites. This period is defined as persistent infection (4). Also recurrent infections defined as intermittent periods of viral shedding have frequently been observed $(5,6)$. The observation that HCMV can be transmitted by bloodtransfusions $(7,8)$ and organ transplants $(9,10)$ obtained from healthy individuals in whom viral shedding was not observed $(11,12)$ lead to the conclusion that a HCMV infection can become latent. This latent state can be defined as an infection in which the viral genome is present but no infectious wirus is produced $(13,14,15)$. Reactivation from this latent state into an active infection leading to endogenous reinfection can cause serious disease in severe immunocompromised individuals like transplant recipients and AIDS patients (1).

The question which cells harbor the latent virus has not been clearly answered yet. Earlier studies suggested that circulating lymphocytes contained latent HCMV (16) and in another study it was suggested that mononuclear cells in the kidney contained latent HCMV (17). Later on HCMV DNA was detected in vascular smooth muscle cells (18, 19, $20,21)$ and a role for this virus in the pathogenesis of atherosclerosis was postulated. Also HCMV immediate early antigens but mot late antigens could be detected in cells located in different organs such as liver, spleen, heart, kidney, and adrenals (22). Cilrulating blood mononuclear cells obtained from healthy blood donors were also cemonstrated to contain HCMV DNA $(23,24,25,26,27)$, however, other investigators failed to demonstrate the presence of HCMV DNA in peripheral leucocytes $(28,29)$. Also in bone-marrow cells obtained from healthy individuals HCMV nucleic acids could be detected, and recently two novel classes of HCMV latency associated transcripts have been described in these cells $(30,31)$.

\section{Aims of the study}

The aims of the present study were:

1. To develop methods suitable for the detection of HCMV nucleic acids in human tissues.

2. To study the presence of HCMV in the human arterial wall.

3. To investigate other human tissues obtained from healthy subjects for the presence of HCMV and characterise the cell type(s) in which the virus is present.

\section{Outline of the study}

The outline of the study is as follows.

In chapter 2 a review is presented of current literature concerning HCMV infection with special interest on the data related to epidemiology, tissue tropism during active infection and during latency.

In chapter 3 and 4 the presence of HCMV in arteries obtained from atherosclerotic and non-atherosclerotic patients is investigated with special emphasis on HCMN DNA, viral antigens and infectious viruis.

In chapter 5 the findings of chapters 3 and 4 are extended

to other arteries not prone for the development of atherosclerosis and an estimation of 
the HCMV wiral load in the arterial wall is presented.

In chapter 6 the detection of HCMV DNA in a wide variety of human lissues obtained from previously healthy individuals is presented.

In chapter 7 the presence of HCMV DNA in spleen, kidney, and liver specimen obtained from previously healthy trauma victims is described and sequence analysis data are presented indicating that indeed HCMV is detected and that probably during latency more than one latent HCMV genotype can be present within a single individual.

All our findings are discussed in chapter 9.

In chapter 10 the main conclusions of this study are summarized

\section{References}

1. Ho M. Cytomegalovirus biology and infection. New York; Plenum Medical Book Co. 1991.

2. Jordan MC "Rousseau WE, Steward JA, Noble GR, Chin TDY, Spontaneous cytomegalovirus mononucleosis: clinical and laboratory observations in nine cases. Ann.Intern.Med. 1973; 97:153-160.

3. Horwitz CA, Henle W. Henle G. Diagnostic aspects of the cytomegalovirus mononucleosis syndrome in previously healthy persons. Postgrad.Med. 1979; 66:153-158.

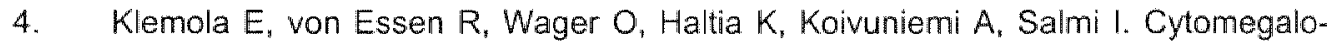
virus mononucleosis in previously healthy individuals. Ann.Intern.Med. 1969; 71:11-19.

5. Reynolds DW, Stagno S, Hosty TS, Tiller m, Alford JA Jr. Maternal cytomegalovirus excretion and perinatal infection. N.Engl.J.Med. 1973; 289:1-5.

6. Stagno S, Reynolds DW, Tsiantos a, et al. Cervical cytomegalovirus excretion in pregnant and nonpregnant women: suppression in early gestation. J.Infect.Dis. $1975 ; 133: 522-7$.

7. Prince AM. Szmuness W, Millian SJ. A serologic study of cytomegalovirus infections associatled with blood transfusions. N.Engl.J.Med. 1971; 284:1125-1131.

8 Adler SP. New insights into human cytomegalovirus infections. Prog.Med.Virol. $1990 ; 37: 136-155$.

9. Ho M, Suwansirikul S, Dowling JN, Youngblood LA, Armstrong JA. The transplanted kidney as a source of cytomegalovirus infection $\mathbb{N}$. Engl.J.Med. 1975; 293:1. $109-1112$.

10. Betts RF. Freeman RB, Douglas RG Jr, Talley TE, Rundell B. Transmission of cytomegalovirus infection with renal allograft. Kidney Int. 1975; 8:385-392.

11. Chou S. Acquisition of donor strains of cytomegalovirus by renal-transplant recipients. N.Engl.J.Med. 1986; 314:1418-1422.

12. Chou $\mathrm{S}$. Cytomegalovirus infection and reinfection transplanted by heart transplantation. J.Infect.Dis. 1987; 155:1054-1056.

13. Stevens JG. Human herpeviruses; a consideration of the latent state. Microbiol.Rev. 1989; 53:318-332.

14. Banks AB, Rouse BT. Herpesviruses * immune escape artists? Clim.Infect.Dis. 1992: 14:933-941.

15. Fraser NW, Block TM, Spivack JG. The latency-associated transcripts of herpes simplex virus: RNA in research and function. Virol. 1992; 191:1-8.

16. Schrier RD. Nelson JA, Oldstone BA. detection of human cytomegalovirus in peripherall blood lymphocytes in a natural infection. Science 1985; 230:148-151.

17. Gnann JW. Ahimen J, Svalander C, Olding L, Oldstone MBA, Nelson JA. Inflammatory cells in transplanted kidneys are infected by human cytomegalovirus. Am. J.Pathol. 1988; 132:239-248. 
18. Petri BL, Meinick JL, Adam E, Burek J, McCollum CH, DeBakey ME. Nucleic acid sequences of cytomegalovirus in cells cultured from human arterial lissue. J. Infect. Dis. 1987; 155:158-159.

19. Vamashiroya HM. Ghosh L. Yang $R$. Robertson AL. Herpes viridae in the coronary arteries and aorta of young trauma victims. Am. Wi.Pathol. 1988; 130:7179.

20. Tanaka $S$, Toh $Y$, Komori $K$, Okadoma $K$, Sugimachi $K$. Possible role of cytomegalovirus in the pathogenesis of inflammatory aortic didease: a preliminary report. J.Vasc. Surg. $1992 ; 16: 274-279$.

21. Melnick JL. Hu C. Burek J, Adam E, Debakey ME. Cytomegalovirus DNA in arterial walls of patients with atherosclerosis. J.Med. Virol, 1994; 42:170-174.

22. Tookkey CB, Carrigan DR. Immunohistochemical detection of an immediate early antigen of human cytomegalovirus in normal tissues. U.Infect.Dis. 1989: 160:741751.

23. Stanier $P$, Taylor DL, Kitchen AD, Wales $N$. Tryhorn $Y$, Tyms AS. Persistence of cytomegalovirus in mononuclear cells in peripheral blood from blood donors. Br.Med.J. 1989; 299:897-898.

24. Bevan IS, Daw RA, Day PJ, Ala FA, Walker MR. Polymerase chain reaction for the detection of human cytomegalovirus infection in a blood donor population Br.J. Haematol. 1991; 78.94-99.

25. Taylor-Wiedeman J, Sissons JGP, Borysiewics LK, Sinclair JH. Monocytes are a major site of persistence of human cytomegalovirus in peripheral blood mononuclear cells. J.Gen. Virol. 1991; 72:2059-2064.

26. Taylor-Wiedeman J, Hayhurst GP, Sissons JGP, Sinclair JH. Polymorphonuclear cells are not sites of persistence of human cytomegalovirus in healthy individuals. J.Gen. Virol. 1993; 74:265-268.

27. Zhang LJ, Hanff P, Rutherford $C$, Churchill WH, Crumpacker CS. Detection of human cytomegalovirus DNA, RNA, and antibody in normal donor blood. JI.D. $1995 ; 171: 1002-6$.

28. Bitch $A$, Kirchner $H$, Dupke R, Bein G. Failure to detect human cytomegalovirus DNA in peripheral blood leucocytes of healthy bloos donors by the polymerase chain reaction. Transfusion 1992; 32: 612-617.

29. Urushibara $N$, Kwon KW. Takahashi TA, Sekiguchi S. Human cytomegalovirus DNA is not detectable with nested double polymerase chain reaction in healthy blood donors Vox Sang 1995; 68:9-14.

30 Kondo $K$. Mocarsky ES. Cytomegalovirus latency and latency-specific iranscription in hematopoietic progenitors. Scand J.Infect Dis. Suppl. 1995; 99:63-67.

31. Kondo $K$, Xu J Mocarski ES. Human cytomegalowirus latent gene exprssion in granulocyte-macrophage progenitors in culture and in seropositive individuals. Proc. Nall. Acad. Sci. USA 1996; 93:11137-11142. 


\section{CHAPTER 2}

\section{General introduction}

2.1. Introduction

2.2. Epidemiology of HCMV infections

2.2.1. Epidemiology of HCMV in the general population

2.2.2. Epidemiology of HCMVin the immunocompromised host

2.3. HCMW gene expression

2.3.1. In vitro HCMV infection of permissive cells

2.3.2. In vitro HCMV infection of non permissive cells

2.3.3. In vitro HCMV latency models

2.4. Distribution of HCMV in the human body

2.4.1. Tissue distribution during active HCMV disease

2.4.2. Tissue distribution of HCMV in non HCMV related disease

2.4.3. Tissue distribution of HCMV in healthy subjects

2.5. Animal models for CMV latency

2.6. References 


\subsection{Introduction}

Infections with human cylomegalovirus (HCMV) are common and the prevalence of these infections as based on serological studies ranges from $40-90 \%$ (1). In the immunocompetent individual, clinical disease is a relatively exceptional ewent (1). In immunocompromised patients, like transplant recipients (2) and ADS patients (3), HCMV can cause diseases as interstitial pneumonits and retinitis. In solid organ transplant recipients, the infection mostly accurs by endogenous reinfection due to reactivation of latent virus present in the donor organ but also reactivation of latent virus of the recipient is possible $(4,5,6,7)$. In AlDS patients and in allogeneic bone marrow transplant recipients, most infections result from reactivation of latent virus already present in the host (8). The exact nature of the cells from which the latent HCMV reactivates, however, remains elusive. Some investigators suggest that peripheral leucocytes $\left(\theta_{\text {, }}\right.$ $10,11)$, vascular smooth muscle cells $(12,13,14)$, and various cellypes in spleen, viver, kidney, heart and adrenals $(15,16,17)$ contain HCMV DNA during latency.

The exact localisation of latent HCMV is still not clearly defined. In this chapter, a brief review of the literature relevant to the understanding of HCMV latency is presented.

\subsection{Epidemiology of HCMV infections}

As suggested by Ho (18), epidemiology of HCMV infections can be devided in two fields. One field describing the normal patterns of spread in the general population, and a second field describing the HCMV spread in a non-immunocompetent population. From both fields much can be learned about the complex biology of HCMV.

\subsubsection{Epidemiology of HCMV in the general population}

Infections with HCMV have a history in science of more than 9 decades. The typical inclusion bodies detected in organs of newborns were first discovered in 1904 when Ribbert (19) described "protozoan-like" cells in the kidney of a stillborn. The presence of these typical inclusion bodies in the organs of newborns was confirmed by several other authors and the disorder was named cytomegalic inclusion disease (CID). The causative agent however remained unknown and only newborns were considered to be vulnerable. In 1932. Farber and Wolbach (20) demonstrated the presence of inclusion bodies in the submaxillary glands but also in other organs of $12 \%$ of infants dying of various diseases. These findings showed that CID was not limited to newborns and that the prevalence was probably much higher than presumed. During the late fifties it was demonstrated that the causative agent of CID was an unfectious non-bacterial microorganism $(21,22,23)$ and in 1960 the micro-organism causing cytomegalic inclusion disease was identified, and termed Human Cytomegalovirus (HCMV) (24). In 1965 it was shown by Kemola (25) that in healthy individuals HCMV infection can lead to a mononucleosis.like disease. The characteristics of this disease closely resembled the clinical symptoms occuring in infectious mononucleosis caused by Epstein Barr virus where atypical lymphocytes are also observed. Until now the mononucleosis-like syndrome is the only disease occuring in the nomal population were a causative role for HCMV is firmly established. Other infrequent diseases caused by HCMV are: hepatitis, the Guillain-Barre" syndrome, meningoencephalitis, myocarditis, and thrombocytopenia-hemolytic anemia (1). Recently, much is speculated on the role of HCMV in the development of atheroscierosis $(26,27,28)$.

During infection, HCMV induces a humoral and cellular immune respons. Due to the development of new serological techniques in the 1960's, sensitive methods became 
avalable for the sero-epidemiological study of HCMV. Using these methods it was shown that the prevalence of HCMV antibodies was high, ranging from 40 to $100 \%$ depending largely on the socio-economic status (29). Analysis of age-related prevalence showed two periods of increased infection rates during life. The first was the perinatal period, and the second occurs during the years of sexual maturity. In the perinatal period transmission can occur vertically from mother to child: at birth by passing a contaminated uterine cervix (30) and later by breast-feeding (31, 32). Horizontal transmission can also occur, especially in day care centers, from other infected children (33). During the years of sexual maturity transmission accurs during heterosexual and homosexual intercourse. Both the uterine cervix and the semen of healthy adults can contain HCMV $(34,35)$. In some cases HCMV strains isolated from sexual partners had identical DNA restriction fingerprinting patterns proving this mode of transmission ( 36 ).

\subsubsection{Epidemiology of HCMV in the immunacompromised host}

In solid organ transplantations, HCMV infection occurs in $50 \%-100 \%$ of the recipients (1, $2,4,18,47,48,49,50$ ). These infections can be divided in three groups. 1) primary infection of a seronegative recipient caused by HCMV present in the donor organ. 2) reactivation of latent HCMV in the seropositive recipient and 3) reinfection of a seropositive recipient by HCMV present in the donor organ. The clinical manifestations of these HCMV infections range from subclinical to often fatal disease $(1,18)$ and are related to the type of transplantation and the degree of immunosuppression used. In general, primary infections tend to be more severe in these patients than in immunocompetent individuals $(2,49,51)$.

In bone marrow transplant recipients, the major risk factor for severe HCMV disease is HCMV seropositivity $(1,8,52)$. In these patients HCMV infection is caused by reactivation of latent virus.

HCMV can also be transmitted by transfusion of blood and/or blood products (53). The strict exclusion of blood obtained from seropositive donors indeed decreased the risk of HCMV transmission (54). Also in neonates HCMV can be transmitted by bloodtransfusions $(55,56)$. There have been numerous efforts to isolate HCMV from human blood, but active virus could never be detected (1), suggesting that the virus is present in a latent, non-replicating state.

From the epidemiology of HCMV it can be concluded that alter primary infection, HCMV probably develops a lifelong relationship with its host, a status called latent infection or latency $(57,58)$.

During the last decades several definitions have come into use to describe the complex biological behaviour of HCMV. It therefore is necessary to discuss some of them. Primary infection is the infection obtained for the first time in life (i.e. in a seronegative individual). It results in an active infection meaning that there is viral replication in warious cell types and in several organs. HCMV disease however is very rare $(1,15,17$, 20). In some subjects primary infection can be followed by a prolonged period of HCMV replication defined as a persistent infection (59). Also intermittent periods of viral shedding defined as recurrent infections have frequently been observed $(30,60)$. Later on, no infectious HCMV can be detected anymore, so the virus has become latent (61). A definition of this latent state is proposed by Banks and Rouse (62) as a persistent infection in which the viral genome is present, but gene expression is absent or limited and infectious virus is not produced. Later Fraser (63) suggested that the capacity to reactivate from this latent state into an active infection should be included in this definition. Reactivation from this latent state into active infection occurs in the immuno- 
compromised host but perhaps also in the "normal" i.e. immunocompetent host, as has been known for other herpeswiruses such as human simplex virus which can reactivate after stimuly as UV-irradiation, fever, and even stress (64).

\subsection{HCMV gene expression}

HCMV, a member of the herpesviridae, is a large, enveloped, doublestranded DNA virus (65) with a genome consisting of 235 kilo basepairs containing 208 predicted open reading frames probably encoding more than 200 polypeptides (66). The functions of many of these polypeptides are not well understood. Some are regulatory proteins, like the immediate early gene products $\mid E-1$ and $\mid E-2$ (67). Both proteins control viral replication $(65,68,69)$ Other proteins make up the infectious viral particle $(65,70)$. HCMV has a restricted host-range and in vitro only human fibroblasts (65), vascular smooth muscle cells (71), differentiated macrophages (72) and some cell lines after induction of differentiation $(73,74,75)$ are permissive. Productive replication is not observed in other cell types and viral expression is often limited to the immediate-early genes $(65,67,68)$.

\subsection{1. in vifro HCMV infection of permissive cells}

Attachment to and penetration of the cell by fusion of the viral envelope and the plasma membrane (76) is completed within 5 minutes (77). Thereafter HCMV is transported to the nucleus of the cell and within 30 minutes viral gene products can be detected (78). In the nucleus of the cell the viral DNA is transcribed in a stepwise fashion $(79,80)$. This replication cycle is marked by three distinct phases: immediate-early (IE), early ( $E$ ), and late (L) based on the time of synthesis after entry of HCMV into the cell.

The IE-genes are transcribed immediately after viral entry into the cell. Proteins coded for by these genes can be detected using monoclonal antibodies as soon as 30 minutes after infection $(78,80)$. The gene segment coding for the most abundantly transcribed IE-proteins is located in the unique long segment of HCMV $(81,82,83)$. Besides the major IE-genes (UL122, UL123) there are three other regions of IE transcription (US3, UL36, UL37) (79). The relative amount of RNA transcribed from these regions is low. Initial transcription of IE-genes takes place in the absence of viral protein synthesis by cellular polymerases, probably RNA polymerase II (B3). Two IE-gene products, IE-1 (UL123) and IE-2 (UL122) are abundantly translated. The role of the IE-1 protein appears to be autoregulatory in activating HCMV IE-sequences but probably also in activating cellular genes. The IE-2 protein plays a central role in the switch from IE- to E-gene expression $(84,86)$. Part of the $\mid \mathrm{E}-2$ gene is also abundantly transcribed during $\mathrm{L}-\mathrm{gene}$ expression and functions as a repressor of IE-gene expression during this period (86. 87). The reason for this is not yet clear. After transactivation of E-genes by IE-2 proteins these genes remain active until the late transcription period. E-genes are encoded from a large proportion of the viral genome but the role of these genes, besides transactivation of L-genes, is poorly understood $(67,79)$. During early times of infection. proteins needed for viral DNA replication are produced $(67,79)$. Proteins encodled by L-genes are mainly translated after viral DNA synthesis has started, although they can be transcribed at early times of infection $(67,79)$. Products of both $E-$ genes and L-genes are assembled into infectious HCMV particles, and are called "structural proteins" (70). Viral assembly mainly occurs in the cell nucleus were DNA is packaged into capsids. The envelope of the progeny virions is acquired from the nuclear membrane $(79,88,89)$. From there on the viral particles are transported via the Golgi apparatus to the cell surface and are probably released from these cells by an exocytic 


\subsection{2. in vitro HCMV infection of non-permissive cells}

In vitro it seems that mainly human fibroblasts fully support HCMV replication. In vitro infection of other celtypes only supports limited viral replication $(71,72,73,74,75)$, or no production of progeny virus at all $(79,91)$. The block to HCMV replication in nonpermissive cells occurs at a step prior to viral DNA synthesis and is restricted to expression of $E$ - and sometimes to E-genes $(92,93,94,95)$. The nature of the block suppressing lurther viral transcription in these nonpermissive cell types is not clear. Some cell types like monocytes and unstimulated macrophages which are nonpermissive in vitro can support HCMV replication after induction of differentiation $(96,97)$. However, the mechanism responsible for this switch also remains unclear.

\subsection{3. in vitro HCMV latency models}

Several attemps have been made to establish an in vitro latency model for HCMV. Firstly by in vitro induction of differentiation of nonpermissive cell types as macrophages (96, 97) and human embryonal carcinoma cells (74). Secondly by infecting and incubating human thyroid papillary carcinoma cells (TPC-1) at $40.5^{\circ} \mathrm{C}$ with HCMV. Under these conditions the cultures could be maintained for 65 days without detection of infectious virus. However, by decreasing the culture temperature to $37^{\circ} \mathrm{C}$ infectious virus could be detected (98). Thirdly by treating fibroblasts with aciclovir and interferon-gamma and maintaining cultures at $40.5^{\circ} \mathrm{C}(99)$. Under these conditions viral replication could be stopped for more than 70 days and returning to normal cuiture conditions did restore HCMV replication. Most of these models demonstrated a restricted transcription of IEand sometimes E- genes, but never of L-genes during the presumed latent state. Recently two novel classes of HCMV latency associated transcripts have been detected in bone marrow aspirates from healthy HCMV seropositive individuals (100, 101). Both transcripts are complementary to the $I E-1$ and $I E-2$ gene regions. One class, sense transcripts, is encoded in the same direction as productive phase transcripts and encodes a 94 aa protein. The other class, antisense transcripts, is complementary to the $\mid E-1$ gene exons $2-4$ and possibly encode for a 152 and a 154 aa protein. Antibody to these 94 and 154 aa proteins is detectable in the serum of healthy HCMV seropositive individuals. The role of these proteins in the establishement of a latent infection remains unknown. These findings could not be reproduced by others (102, 103) who also detected HCMV genomes in bone marrow cellis, but were unable to detect HCMV lytic gene expression (i.e. IE-1 and IE-2 sense transcripts).

From these in vitro data it could be concluded that after penetration of HCMV into a cell Iranscription of immediate early genes starts and, depending on the cell type, transactivation of $E$ - and $L$ - genes will or will not follow. Based on these in vitro models it is possible that after HCMV infection $U E$-genes are transcribed in most cell types and probably these genes are also transcribed during latency.

\section{4. distribution of HCMV in the human body}

HCMV antigens and/or nucleic acids have recently been detected in various samples obtained from patients with or without active HCMV infection. Furthermore HCMV DNA and/or antigens have been detected in blood obtained from healthy blood donors. From 
these data it can be concluded that HCMV shows a wide tissue distribution not only during active infection, but probably also during latency.

\subsection{1. tissue distribution of HCMV during active infection}

As has been described in previous sections, severe HCMV infections occur in immunocompromised patients. In this group of patients most studies on the tissue distribution of active HCMV infection are performed. By in situ DNA hybridization (1SH). HCMV nucleic acids could by demonstrated in lung, pharynx, lymph node, adrenall, liver, kidney, small intestine and salivary gland samples obtained from AIDS patients with clinical active HCMV disease (104). Also in solid organ tranplantation recipients, HCMV nucleic acids and antigens could be detected by $1 \mathrm{SH}$ in various organs $(1,16,105,106,107,108)$. Based on histopathological findings, mostly epithelial cells seemed targets for viral replication (1), but by using ISH also a variety of other cell types including fibroblasts, and endothelial cells were found to contain wiral nucleic acids $(105,106,107,108)$.

During active HCMV infection the wirus can be readily detected in blood leucocytes using tissue culture techniques, $1 S H$, and polymerase chain reaction (PCR) $(1,15,109$, $110,111)$. HCMV could not only be detected in monocytes and granulacytes, but also in CD4+, CD8+ and CD19+ Iymphocytes (111).

\subsubsection{Tissue distribution in potentialy HCMV related disease}

The relationship between HCMV and disease has been firmly established by using histopathological techniques (see section 2.2.1). Later on HCMV has been associated with several "new" diseases primarily based on the detection of HCMV DNA and/or RNA in laesions typical for the disease under investigation. Already in 1981, HCMV DNA was detected in Kaposi"s sarcoma and a role for this virus in the pathogenesis of this disease was suggested (112). Later it became obvious that not HCMV but another herpesvirus (human herpesvirus 8 ) played a causative role $(113,114)$. HCMV DNA was also detected in human tonsillar lymphocytes (115), the human cervix (116), lymph nodes of patients with angioimmunoblastic lymphadenopathy (117), and in various other tisues (1). Based on the observation that an avian herpesvirus named Marek's disease virus (MDV) can cause atherosclerosis in chickens (118), a role for HCMV in the initial events leading to human atherosclerosis was suggested $(26,28,119,120)$. Indeed HCMV DNA could be detected in samples of carotid arteries and abdominal aortas obtained during vascular reconstructive surgery $(12,121,122)$, but also in samples of coronary arteries and abdominal aortas of young trauma victims with minimal signs of atherosclerotic disease (23).

The question now is whether there is a causal relationship between the presence of HCMV nucleic acids in the laesions and the development of the disease. A possible mechanism might be inhibition of the tumor suppression protein p53 by HCMV proteins as has been demonstrated in patients who develop restenosis after coronary angioplasty (123).

\subsubsection{Tissue distribution of HCMV in previously healthy subjects}

To date, only a limited number of studies have been performed to detect $\mathrm{HCMV}$ in tissue samples obtained at autopsy from previously healthy individuals. In one study (17) HCMV immediate early antigens could be demonstrated with monoclonal antibodies 
in kidney, spleen, lver, ung, and brain tissues derved from HCMV-seropositwe healthy individuals. In another study. HCMV nucleic acids could be detected by DNA hybridization techniques with a DNA probe reactive with immediate early sequences in splenic tissues of organ donors whthout clinical or laboratory confmed active HCMV infection (124). Also bone marrow progenitor cells from healthy individuals can contain HCMV DNA as demonstrated by polymerase chain reaction (PCR) (125). More data are available on the presence of HCMV DWA in leucocyles obtaned from heathy blood donors. According to several reponts, $40-80 \%$ of blood donors have detectable HCMV DNA manly in blood mononuclear cells $(9,10,11,126,127)$. These data, however, are not conclusive since other investigators tailed to detect HCMV DNA in leucocytes of healthy blood donors $(128,129)$. Most reports only use a PCR primer set reactive with the major mmediate early gene (mostly UL123) $(9,11,126,128,129)$ to detect HCMV DNA. Since immediate early sequences are highly conserved among the herpesviridae it is possible, abeit unlikely, that another herpesvirus was detecled. Only in the report of Bevan et al.(10) three different primer sets reactive with HCNV DNA derved from the immediate early region (UL123), the HXEF6 region or the GP64 region (UL83) were used. In this study all HCMV-PCR positive blood samples were simultaniously positive with all three primer sets suggesting that indeed the whole viral genome is present.

\subsection{Animal models for HCMV latency}

There are several animal models for CMV (130, 131) but in only two the murine CMV model and the rat CMV model data are available concerning CMV latency (58). The murine cytomegalovirus (MCMW) is extensively investigated. During active infection in mice MCMV closely resembles HCMV with respect to tissue distribution and many organs support viral replication (127). MCMV can be detected in blood mononuclear cells $(132,133,134$,$) , the wer (135), the spleen (136) and the skin (137). After entry$ into the cell MCMV is also transcribed in a stepwise fashion (138). MCMV readily establishes a latent infection (139) and during latency viral genomes can be detected in a variety of organs like brain, heart, kidney liver "lung, spleen, and salivary gland, but not in levicocytes as demonstrated by PCR and RT-PCR $(140,141,142,143)$. It aiso has been demonstrated that immediate early genes are transcribed in spleens of latently infected mice (144). The rat cytomegalovirus (RCMV) on the other hand is a more convenient model for transplantalion experments. The RCMV also closely resembles the HCMV in both infection pattern (145) and molecular biology (146, 147, 148). 11 also establishes a latent infection with can be transmitted to a suitable host by transplantatlon (149, 150). The wirus also reactivates under conditions of immunosuppression (151). Until now no data are awalable on the localization of latent RCMV nor on the transcriptional program during latency.

\subsection{References:}

1. Ho M. Cytomegalovirus biology and intection. New York; Plenum Medical Book Co. 1991.

2. Rubin RH. Impact of cytomegalovirus infection on organ transplant recipients. Rev.nfect.Dis. $1990 ; 12: 5754-5766$.

3. Schooley RT. Cytomegalovirus in the setting of infection with human immunodeftciency virus (see comments). Rev.nfect.Dis. 1990; 12:5811-S819.

4. Ho M, Suwansirikul S, Dowling JN, Youngblood LA, Armstrong J. The transplanted kianey as a source of cytomegalovirus infection N.Engl.J.Med. 1975; 293:1$109-1112$.

5. Bets RF, Freeman RB, Douglas RG d", Talley TE, Rundell B. Transmission of 
cylomegalovirus infection with renal allograft. Kidney Int. 1975: 8:385-392.

b. Chou S. Acquisition of donor strains of cytomegalovirus by renal-transplant recipients. N. Engl.J.Med. 1986; 314:1418-1422.

7. Chou $\$$. Cytomegalowrus infection and reinfection transplanted by heart trans. plantation. Unfect Dis. 1987 ; $155: 1054-1056$.

8. Rubie H, Attal M, Campardou AM, Gayet-Mengelle C. Payen C, Sanguignol F, Calot JP, Charlet JP, Robert A, Huguet F, Puel J, Pris J, Laurent G. Risk factors for cytomegalovirus infection in BMT recipients transfused with seronegative blood products. Bone Mar Transpl. 1993: ??:209-214.

9. Stanier $P$, Taylor DL, Kitchen AD, Wales $N$, Tryhorn $Y$, Tyms AS. Persistence af cytomegalovirus in mononuclear cells in peripheral blood from blood donors. Br.Med.J. 1989; 299.897-898.

10. Bevan 1S, Daw RA, Day PJ, Ala FA, Waker MR. Polymerase chain reaction for the detection of human cytomegalowirus infection in a blocd donor population Br.J Haematol. 1991; 78:94-99.

11. Taylor-Wiedeman J, Sissons JGP, Borysiewics LK, Sinclair JH. Monocytes are a major site of persistence of human cytomegalovirus in peripherall blood mononuclear cells. J.Gen.Virol. 1991; 72:

2059-2064.

12. Petri BL, Meinick JL, Adam E, Burek $J$, McCollum $\mathrm{CH}$, DeBakey ME. Nucleic acid sequences of cytomegalovirus in cells cultured from human arterial tissue. J.infect.Dis. 1987; 155:158-159.

13. Yamashiroya HM, Ghosh $L$, Yang $R$, Robertson AL. Herpes viridae in the coronary arteries and aota of young trauma victims. Am.J.Pathol. 1988; 130:7179.

14. Tanaka $S$, Toh $Y$, Komori K, Okadoma K. Sugimachi K. Possible role of cytomegalovirus in the pathogenesis of inflammatory aortic didease: a preliminary report. J.Vasc.Surg. 1992; 16:274-279.

15. Schrier RD, Nelson JA. Oldstone BA. detection of human cytomegalowirus in peripheral blood lymphocytes in a natural infection. Sicience 1985; 230:148-151.

16. Gnann JW, Ahmen J, Svalander C, Olding L, Oldstone MBA, Nelson JA. Inflammatory cells in transplanted kidneys are infected by human cytomegalovirus. Am. J.Pathol. 1988; 132:239-248.

17. Toorkey $\mathrm{CB}$, Carrigan DR. Immunohistochemical detection of an immediate early antigen of human cytomegalovirus in nomal tissues. Il.Infect. Dis. 1989; 160:741 751.

18. Ho M. Epidemiology of cytomegalovirus infections. Rev.Infect.Diseas. 1990; 12 (suppl.7):S701-S710.

19. Ribbert Ueber protozoenartige zellen in der niere eines syphilitischen neugeborenen und in der parotis von kindern. Centralbl.Algem. Pathol.u.Pathol.Anat. 1904; 23.945-948.

20. Farber $S$, Wolbach SB. Intranuclear and cytoplasmic inclusions (protozoanlike bodies) in the salivary glands and other organs of infants. Am.J.Pathol. 1932; $8: 123-35$.

21. Rowe WP, Hartley JW. Waterman S. Turner HC, Huebner Ru. Cytopathogenic agent resembling human salivary gland virus recoverd from tissue cultures of human adenoids. Proc. Soc. Exp.Biol.Med. 1956; 92:418-424.

22. Weller TH, Macauley $1 \mathrm{C}$, Graig JM, Wirth P. Isolation of intranuclear inclusion producing agent from infants with itnesses resembling cytomegalic inclusion disease. Proc. Soc. Exp.Biol.Med. 1957:94:4-12.

23. Smith MG. Propagation in tissue cultures of a cytopathic virus from human salivary gland wirus (SGV) disease. Proc.Soc.Exp.Biol.Med. 1956;92:424-430.

24. Weller TH,Hanshaw JB, Scott DE. Serologic differentiation of virusses responsible 
for cytomegalic inclusion disease. Virol. $1960 ; 130-132$.

25. Klemola $E$, Kaariainen L. Cytomegalovirus as a possible cause of a disease resembling infectious mononucleosis. Br.Med.J. 1965; 1:1099-1102.

26. Hajar DP. Viral pathogenesis of atherosclerosis. A.J.P. 1991: 139:1195-1211.

27. Consigny PM. Pathogenesis of atherosclerosis. A.J.R. 1995; 164:553-558.

28. Melnick $\mathrm{JL}$, Adam E, DeBakey ME. Possible role of cytomegalovirus in atherogenesis. J.A.M.A. 1990; $263: 2204-2207$.

29. Yow MD, Williamson DW. Leeds LJ, Thompson P, Woodward RM, Walmus BF, Lester JW, Six HR, Griffiths PD. Epidemiological characteristics of cytomegalovirus infection in mothers and their infants. Am.J.Obstet.Gynecol. 1988; 158:4189. 1195.

30. Reynolds DM, Stagno $S$, Hosty TS, Alford CA Jr.. Maternal cytomegalovirus excretion and perinatal infection. N. Engl.J.Med. 1973: 289:1-5.

31. Stagno $S$, Reynolds DW, Pass RF, Alford CA. Breast milk and the risk of cytome. galovirus infection N.Engl.J.Med. 1980; 302:1073-1074.

32. Hayes $K$, Danks DM, Gibas H. Cytomegalovirus in human milk. N.Engl.J.Med. $1972 ; 287: 177-178$.

33. Pass RF, August AM, Dworsky M. Cytomegalovirus infection in a day care center. N.Engl.J.Med. 1982; 307:477-479.

34. Chandler SH, Handsfield HH, McDougall JK. Isolation of multiple strains of cylomegalovirus from women attending a clinic for for sexually transmitted dieases. J.Infect.Dis. 1987; 155:655-660.

35. Lang DJ, Kummer JF. Demonstration of cytomegalovirus in semen. N.Engl.J.Med. $1972 ; 287: 756-758$.

36. Handsfield $H H$, Chandler SH, Caine VA, Meyers JD, Corey L, Medeiros $E_{*}$ McDougall JK. Cytomegalovirus infection in sex partners: evidence for sexual transmission. J.Infect. Dis. 1985; 151:344-348.

37. Marker SC, Howard RJ, Simmons RL, et al Cytomegalovirus infection: a quantitative prospective study of 320 consecutive renal transplants. Surgery 1981; 89:660-671.

38. Peterson PK, Balfour HH Jr, Marker SC, Fryd DS, Howard RJ, Simmons RL. Cytomegalovirus disease in renal allograft recipients: a prospective study of the clinical features, risk factors and impact on renal transplantation. Medicine 1980; 59:283-300.

39. Rand $\mathrm{KH}_{3}$ Polland RB, Merigan TC. Increased pulmomary superintections in cardiac transplant patients undergoing primary cytomegalovirus infection. N.Engl.J.Med. 1978; 298:951-3.

40. Aldrete JS, Sterlij WA, Hathaway BM, Morgan JM, Diethelm AG. Gastrointestinal and hepatic complications affecting patients with renal allografts. Am.J.Surg. $1975 ; 129: 115-24$.

41. Anuras S, Piros J, Bonney WW, Forker EL, colville DS, Corry RJ. Live disease in renal transplant recipients Arch. Intern. Med. 1977; 137:42-8.

42. Luby JP, Brunett W. Hull AR, Ware EJ, Shorey JW, Peters PC. Relationship between cytomegalovirus and hepatic function abnormalities in the period after renal transplantation. Jinfect.Dis. 1974; 129:573-5.

43. Ware AJ, Luby JP, Hollinger B, et al. Etiology of Iiver disease in renall-transplant patients. Ann.Intern.Med. 1979; 91:364-71.

44. Egbert PR. Pollard RB, Gallagher JB, Merigan TC. Cytomegalovirus retinitis in immunosuppressed hosis. Il. Occular manifestations. Ann.Intern.Med. 1980; 93:664-70.

45. Jacobson MA, Mills $\Downarrow$. Serious cytomegalovirus disease in the aquired immunodeficiency syndrome (AIDS). Clinical findings, diagnosis, and treatment. Ann.Intern.Med. 1988; 108:585-94. 
46. Pollard RB, Egbert PR, Gallagher JG, Merigan TC. Cytomegalovirus retinitis in inmunosuppresed hosts. I Natural history and effects of treatment with adinine arabinoside. Ann.Intern.Med 1980; 93:655-64

47. Fiala M, Paine JE, Berne TV, Moore TC. Hente $W$, Montgomerie JZ, Chatterjee SN, Guze LB. Epidemiologie of cytomegalovirus infection afetr transplantation and immunosuppression. J.Intect. Dis. 1975; 132:421-433.

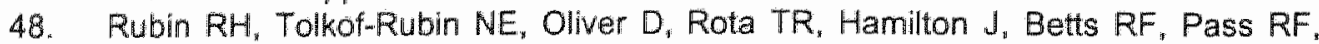
Hillis W. Szmuness W. Farrel ML. Hirsch MS. Multicenter seroepidemiologic study of the impact of cytomegalovirus infection on renal transplantation. Transplantation 1985; $40: 243-249$.

49. Ackerman JR, Lefor WM, Weinstein $S$, el al. Fouryear experience with exclusive use of cytomegalovirus antibady (CMV-Ab)-negative donors for (CMV-Ab)negative kidney recipients. Transplant.Proc. 1988; 20:469-71.

50. Chou SW, Norman DJ. The influence of donor factors other than serologic status on transmission of cytomegalovirus to transplant recipients. Transplantation 1988 ; $46: 89-93$.

51. Ho M. Observations from transplantation contributing to the understanding of pathogenesis of CMV infection. Transpl.Proc. 1991; 23 (suppl.3):104-109.

52. Winston DJ, Ho WG, Champlin RE. Cytomegalovirus infections after allogeneic bone marrow transplantation. Rev.Infect.Dis. 1990; 12 (suppl.7):S776-791.

53. Prince AM, Szuness W, Millian SJ. A serologic study of cytomegalovirus infections associated with blood transfusions. N.Engl..J.Med. 1971; 284:1125-1131.

54. Verdonck LF, de Haan-Hentzen YCE, Dekker AW, Mudde GC, de Gast GC. Cytomegalovirus seronegative platelets and leucocyte poor red blood cells from random donors can prevent primary cytomegalovirus infection after bone marrow transplantation. Bone Marrow Transplant 1987; 2:73-78.

55. Yeager AS, Grumet FC, Hafleigh EB. Bradley JS, Prober CG. Prevention of transfusion-acquired cytomegalovirus infection in newborn infants. J.Pedriatr. $1981 ; 98: 281-7$.

56. Adler SP. Neonatal cytomegalovirus infections due to blood. CRC Crit.Rev.Lab.Sci. 1984; $23: 1-14$.

57. Jordan MC. Latent infection and the elusive cytomegalovirus. Rev.Infect.Dis. $1983 ; 5: 205-215$.

58. Bruggeman CA. Cytomegalowirus and latency: an overview. Virchows Archiv B Cell Pathol. 1993;

64:325-333.

59. Klemola $E$, won Essen $R$, Wager O, Haltia K, Koivuniemi A, Salmi I. Cytomegalovirus mononucleosis in previously healthy individuals. Ann. Intern.Med. 1969; $71: 11-19$.

60. Stagno S, Reynolds DW. Tsiantos $A$, et al. Cervical cytomegalovirus excretion in pregnant and nonpregnant women: suppression in early gestation. J.Infect.Dis. $1975 ; 133: 522-527$.

61. Steven JG. Human Herpesviruses: a consideration of the latent state. Microbiol.Rev. 1989; $53,318-332$.

62. Banks $\mathrm{AB}$, Rouse BT, Herpesviruses-immune escape artists? Clin.infect.Dis. $1992 ; 14: 933-941$.

63. Fraser NW. Block TM. Spivack JG. The latency-associated transcripts of herpes simplex virus: RNA in research and function. Virol. $1992 ; 191: 1-8$.

64. Whitley RJ, Gnann jr JW. The epidemiology and clinical manifestations of herpes simplex virus infections. In: Roizman B, Whitley RJ, Lopez $C_{\text {, ed. The human }}$ herpesviruses, New York, Raven press, LTD 1993.

65. Mocarski ES Jr. Cytomegaloviruses and their replication. In: Fields BN, ed. Fields virology, Philadelphia, lippincott-raven publishers, 1996. 
66. Chee MS, Bankier AT, Beck S, Bohni R, Brown CM, Cerny R, Horsnell $T$. Hutchinson CA. Kouzarides T, Martigneti JA, Preddie E, Satchwell SC. Tominson P. Weston KM, Barrel BG. Analysis of the protein coding content of the sequence of human cytomegalovirus strain AD169. Current topics in microbidlogy and immunology 1990; 154:125-169.

67. Mocarski ES, Abenes GB, Manning WC. Sambucetti LC. Cherrington JM. Molecular genetic analysis of cytomegalovirus gene regulation in growth, persistance, and latency. Curr.Top.Microbiol.Immunol. 1990; 154:47-74.

68. Nelson JA, Gnann Ju, Ghazal P. Regulation and tissue specific expression of human cytomegalovirus. Curr. Top.Microbiol.Immunol. 1990; 154:75-100.

69. Stenberg RM. Immediate-early genes of human cytomegalovirus: organization and function. In Huang ES, ed. Molecular aspects of human cytomegalovirus diseases. Heidelberg: Springer-Verlag, 1992

70. Spaete RR, Gehr RC, Landini MP. Human cytomegalovirus structural proteins. J.Gen. Virol. 1994:75:3287-3308.

71. Tumilowicz JJ, Gawlik ME. Powell BB, Trentin JJ. Replication of cytomegalovirus in human arterial smooth muscle cells. J.Virol. 1985;56:839-845.

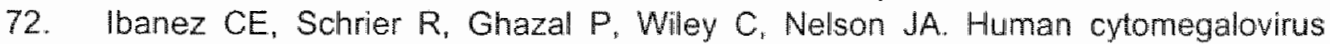
productively infects primary differentiated macrophages. J.Virol. 1991;65:65816588.

73. Dutko FJ. Oldstone MB. Cytomegalovirus causes a latent infection in undifferentiated cells and is activated by induction of cell differentiation. J.Exp.Med. 1981;1$54: 1636-51$.

74. Gonczoll E, Andrew PW. Plotkin SA. Cytomegalovirus replicates in differentiated but not in undifferentiated human embryonal carcinoma cells. Science 1984;224:$159-61$.

75. Shelbourn SL Sissons JG, Sinclair JH. Expression of oncogenic ras in human teratocarcinoma cells induces partial differentiation and permissiveness for human cytomegalovirus infection. J.Gen.Virol. 1989;70:367-74.

76. Compton T. Nepomuceno RR, Nowlin DM. Human cytomegalovirus penetrates host cells by pH-independend fusion at the cellsurface. Virol. 1992; 194:387-95.

77. Smith JD, de Harven E. Herpes simplex virus and human cytomegalovirus replication in W1-38 cells. II. An ultrastructural study of viral penetration. J.Virol. 1974: 14:945-56.

78. Michelson FS. Horodniceanu F, Guillon JC. Immediate early antigens in humari cytomegalovirus infected cells. Nature 1977;270:615-7.

79. Mocarski ES. Cytomegalovirus biology and replication. in: B. Roizman, R.J. Whittey, and C. Lopez, ed. The human herpesviruses. New York, Raven Press, Ltd., 1993: 173-226.

80. Otto SM, Sullivan TG. Malone CL, Stinski MF. Subcellular localization of the major immediate early protein $(\mathrm{E}-1)$ of human cytomegallovirus at early times after infection. Virol. 1988; 162:478-482.

81. Stenberg RM. Thomson DR, Stinski MF. Structural analysis of the major immediate early gene of thuman cytomegalovirus. J.Virol 1984; 49:190.9.

82. Stenberg RM, Witte PR, Stinski MF. Multiple spiced and unspliced transcripts from human cytomegalovirus immediate early region 2 and evidence for a common initiation site within immediate early region 1. J.Viral. 1985; 56:665.75.

83. Wikinson GW, Akrigg A, Greenaway PJ. Transcription of the immediate early genes of human cytomegalovirus strain AD169. Virus Res. 1984;1:101-6.

84. Thomson DR, Stenberg RM, Groins WF, Stinski MF. promotor-regulatory region of the immediate early gene of human cytomegalovirus. Proc.Natl.Acad. Sci.USA $1984 ; 81: 659-63$.

85. Chang CP. Malone CL, Stinski MF.A human cytomegalovirus early gene has 
three inducible promotors that are regulated differentially at various times after infection. J.Virol. $1989 ; 63: 281-290$.

86. Pizzono MC, OHare P. Sha 1, Lafemina RL, Hayward GS. Trans-activation and autoregulation of gene expression by the immediate-early region 2 gene products of human cytomegalovinus. J.Virol. $1988 ; 62: 1167-1179$.

87. Pizzorno MC. Hawward $\mathrm{GS}$. The le2 gene products of human cytomegalovirus specifically downregulate expression from the major immediate-early promotor through a target located near the cap site. J.Virol. 1990; 64:6154-6165.

88. Radsak $K$, Brucher $K H$, Britt $W$, Shiou H. Schneider D, Kollert A. Nuclear compartmentation of glycoprotein $B$ of human cytomegalovirus. Virology 1990; $177.515-22$.

89. Stinski MF, Mocarski ES, Thomsen DR, Urbanowski ML. Membrane glycoproteins and antigens induced by human cytomegalovirus. J.Gen. Virol. 1979; 43:119-29.

90. Kan B, Radeke $R$, Gehrz R. Processing of human cytomegalovirus envelope gycoproteins in and egress of cytomegalovirus from human astrocytoma cells. J.Gen. Virol. 1992; 73:253-60.

91. Price GPA, Schrier RD, Oldstone MBA. Cytomegalovirus infects human lymphocytes and monocytes: virus expression is restricted to immediate-early gene products. Proc. Natl.Acad.Sci.USA 1984; 81:6134-6138.

92. DeMarchi JM. Nature of the block in the expression of some early virus genes in cells abortively infected with human cytomegalovirus. Virology 1983; 129:287-97.

93. Jeang KT, Chin $G$, Hayward GS. Characterization of cytomegalovirus immediate early genes. I. Nonpermissive rodent cells overproducthlE94K protein from CMV (Colburn). Virology 1982; 121:393-403.

94. Lafemina RL, Hayward GS. Differences in cell-type-specific blocks to immediate early gene expression and DNA replication of human, simian and murine cytomegalovirus. J.Gen.Virol. 1988; 69;355-74.

95. Wu T-C, Lee WA, Pizzorno MC, Au W-C, Chan $Y-J$, Hruban RH, Hutchins GM, Hayward GS. Localization of the human cytomegalovirus $2.7-\mathrm{kb}$ major early $B$ gene transcripts by RNA in situ hybridization in permissive and nonpermissive infections. A.J.P. 1992; 141:1247-1254.

96. Ibanez CE, Schrier $R$, Ghazal $P$. Wiley $C$, Nelson JA. Huamn cytomegalovirus productively infects primary differentiated macrophages. J.Virol. 1991; 65:6581. 6588.

97. Lathey JL. Spector SA. Unrestricted replication of human cytomegalovirus in hydrocortisone-treated macrophages. J.Virol. 1991; 65:6371-6375.

98. Tanaka J. Ogura T. Sato H. Hatano M. Establishement and biological charaterization of an in vitro human cytomegalovirus latency model Virol. 1987; 161:62-72.

99. Cockley KD. Rapp F. Analysis of long-term human cytomegalovirus latency in vitro. Intervirology 1986; $26: 129-139$.

100. Kondo K. Mocarsky ES. Cytomegalovirus latency and latency-specific transcription in hematopoietic progenitors. Scand. J. Infect. Dis. Suppl. 1995; 99:63-67.

101. Kondo $K$, Ku J. Mocarski ES. Human cytomegalovirus latent gene exprssion in granulocyte-macrophage progenitors in culture and in seropositive individuals. Proc. Natl. Acad. Sci. USA 1996; 93:11137-11142.

102. Sinclair J, Sissons. P. Latent and persistent infections of monocytes and macrophages. Intervirol. 1996; 39:193-301.

103. Mendelson $M$, Monard $S$, Sissons $P$. Sinclair J. Detection of endogenous human cytomegalovirus in CD34+ bone marrow progenitors. J.Gen.Virol. 1996; 77:3099102.

104. Andersen CB, Detection of cytomegalovirus-infected cells in autopsy material by in situ hybridization. A.P.M.I.S. 1990; 98:363-368.

105. Borisch B, Jahn $G$, Scholl BC, Filger-Brillinger J, Heymer B, Fleckenstein B, 
Muller-Hemelink HK. Detection of tuman cytomegalovius DNA and viak antigens in tissues of different manifestations of CMV infection. Virch.Arch.B.Cell. Pathol. $1988 ; 55: 93-99$.

106. Wober RA, LLoy RV. Cyromegalovitus detection by nonisotopic in siu DNA hybridization and viral antigen immunostaining using a wo-color technicue. Hum.Path. $1988 ; 19: 736.741$.

107. Meyerson D, Hackman RC, Nelson JA. Ward DC, McDougall JK. Widespread presence of histologically occult cytomegalowirus. Hum. Path. 1984: 15:430-439.

108. Weiss LM, Movahed LA, Berry GJ, Billigham ME. In sutu hybridization studies for viral nucleic acids in heart and lung allograft biopsies. A.J.P. 1990; 93:675-679.

109. Bij van der $W$, Schim J, Torensma $R$, Son wan $W$, Tegzess AM, Hauw The $T$. comparison between viraemia and antigenaemia for detection of cytomegatovirus in blood. J.Clin. Microbiol. 1988; $26: 2531-2537$.

110. Dankner WM, McCutchan JA, Richman DD, Hirata K, Spector SA. Localization of human cytomegalovirus in peripheral blood leucocytes by in situ hybridization. J.Infect.Dis. 1990; 161:31-36.

111. Laer von D, Serr A, Meyer-koning U, Kirste G. Hutert T, Haller O. Human cytome. galovirus immediate early and late transcripts are expressed in all major leukocyte populations in vivo. J.Infect.Dis. 1995; $172.365-370$

112. Boldogh 1, Beth E, Huang ES, Kyalwazi SK, Giraldo G. Kaposi"s sarcona: dotecti on of CMV DNA, CMV RNA, and CMNA in tumor biopsies. IAt. J. Cancer 1981; 28:469-474.

113. Moore PS, Chang Y. Detection of herpeswirus-like DNA sequences in Kaposi's sarcoma in patients with and thos without HV infection. N.Engl.J.Med. 1995; $332: 1181-1185$.

114. Cesarman E, Chang Y, Moore PS, Sail JW, Knowles DM. Kaposi"s sarcoma associated herpesvirus-like DNA sequences in AlDS-related body-cavity-based lymphomas. N.Engl.J.Med. 1995; 332:4186-1191.

115. David D. Ravid Z, Morag A. Detection of human cytomegalovirus DNA in human tonsillar lymphocytes. J.Med.Virol. 1987; 23:383-391.

116. Mathijs $J-M_{*}$ Rawlinson WD, Jacobs $S$, Bilous AM, Miliken JS, Dowton DN, Gunningham Al. Cellular localization of human cytomegalovirus reactivation in the cervix. J.Infect.Dis. 1991; 163:921-922.

117. Yu A-M, Song R-L, Y"u Z, Chen Y-P, Wang F-Z Na L-X, Xie G-L Yang M-J. detection of human cytomegalovirus antigen and DNA in lymph nodes and peripheral blood mononuclear cells of patients with angioimmunoblastic lymphadenopathy with dysproteinemia. Arch.Pathol.Lab.Med. 1992; 116:490-494.

118. Fabricant CG, Fabricant J, Minick CR, Litrenta MM. Herpes virus-induced atherosclerosis in chickens. Fed.Proc. 1983; 42:2476-2479.

119. Muscari A, Bozzoli C, Gerratana C, Zaca F, Rovinetti C, Zauli D. La Placa M. Puddu P. Association of serum IgA and $\mathrm{C} 4$ with severe atherosclerosis. Atherascler. 1988; 74:179-186.

120. Grattan MT, Moreno-Cabral CE, Stames VA, Oyer PE. Stinson EB, Shumway NE. Cytomegalovirus infection is associated with cardiac allograft rejection and atherosclerosis. J.A.M.A. 1989; 261:3561-3566.

121. Melnick JL, Petrie BL. Dreesman GR. Burek $₫$, McCollum CH, Debakey ME. Cytomegalovirus antigen within human arterial smooth muscle cells. Lancet 1983 ; ii: 644.647 .

122. Melnick JL, Hu C. Burek J, Adam E. Debakey ME. Cytomegalovirus DNA in arterial walls of patients with atherosclerosis. J.Med.Virol. 1994:42:170-174.

123. Speir E, Modali R, Huang ES, Leon MB. Shawl F, Finkel T, Epstein E. Potential role of human cytomegalovirus and p53 interaction in coronary restenosis. Science 1994; $265: 391-394$. 
124. Kraal YJ, Hendrix MGR, Winen RMH, Peltenburg HG, Hooff van JP. Geelen $\checkmark$ LMC, Bruggeman CA. Detection of latent human cytomegalovirus in organ tissue and the correlation with serological status. Transplant. Int. 1992: 5 (suppl.1):S615616.

125. Minton EJ, Tysoe C, Sinclair JH, Sissons JGP. Human cytomegalovirus infection of the monocyte/macrophage lineage in bone marrow. J.Virol. 1994; 68:40174021 .

126. Taylor-Wedeman J, Hayhurst GP, Sisons JGP, Sinclair JH. Polymorphonuclear cells are not sites of persistence of human cytomegalovirus in healthy individuals. J.Gen.Virol. 1993; 74:265-268.

127. Zhang LJ, Hanff P, Rutherford C, Churchill WH, Crumpacker CS. Detection of human cytomegalovirus DNA, RNA, and antibody in normal donor blood. J.Infect Dis. 1995; 171:1002-6.

128. Bitch A, Kirchner $H$, Dupke $R$, Bein $G$. Failure to detect human cytomegalovirus DNA in peripheral blood leucocytes of healthy bloos donors by the polymerase chain reaction. Transfusion 1992; 32:612-617.

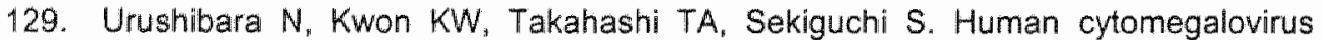
DNA is not detectable with nested double polymerase chain reaction in heaithy blood donors Vox Sang 1995; 68:9-14.

130. Staczek J. Animal cytomegaloviruses. Microbiol. Rev. 1990; 54:247-265.

131. Bruggeman CA, LI F, Stals FS. Pathogenicity: animal models. Scand.J.lnfect.Dis. 1995; Suppl 99:43-50.

132. Collins TM, Quirk MR Jordan MC. Bephasic viremia and viral gene expression in leukocytes during acute cytomegalowirus infection of mice. J.Virol. 1994; 68:630511.

133. Stoddart CA, Gardin RD, Boname JM, Manning WC, Abenes B, Mocarski ES. Peripheral blood mononuclear phagocytes mediate dissemination of murine cytomegalovirus. J.Virol. 1994; 68:6243-53.

134. Bale JF Jr, O'Neil ME. Detection of murine cytomegalovirus DNA in circulating leucocytes harvested during acute infection of mice. J.Virol. 1989; 63:2667-73.

135. Shanley JD, Biczak L, Forman S. Acute murine cytomegalovirus infection induces lethal hepatitis. J.Infect.Diseas. 1993; 167:264-9.

136. Mercer JA, Wiley CA, Spector DH. Pathogenesis of murine cytomegalovirus infection: identification of infected cells in the spleen during acute and latent infections. J.Wirol. 1988; 62:987-97.

137. Abecasis MM, Jiang $X$, O'Neil ME, Bale JF Jr. Detection of murine cytomegalovirus (MCMV) DNA in skin using the polymerase chain reaction (PCR). Microb.Pathogenesis 1993; 15:17-22.

138. Kell GM, Fibi MR Kaszinowski UH. Characterization of the major immediate early polypeptides encoded by murine cytomegalovirus. J.Virol. 1985; 54:422-428.

139. Jordan MC, Pomeroy C. Latent $\mathrm{cmv}$ infection in the mouse. Transplan.Prac. 199 ; 23 (Suppl3).

140. Klotman MA, Henry SC, Greene RC, Brazy OC, Klotman PE, Hamilton JD. Detection of mouse cylomegalovirus nucleic acid in latently infected mice by in vitro enzymatic amplification. J.Infect.Dis. 1990; 161:220-225.

141. Balthesen $M$. Messerle $M$, Reddehase $M J$. Lungs are a major organ site of cytomegalovirus latency and recurrence. J.Virol. 1993; 67:5360-5366.

142. Yuhasz SA, Dissette VB, Cook ML. Stevens JG. Murine cytomegalovirus is present in both chronic active and latent states in persistently infected mice. Virology 1994; 202:272-280.

143. Collins T, Pomeroy $\mathrm{C}$, Jordan MC. Detection of latent cytomegalovirus DNA in divers organs of mice, J.Infect.Dis. 1993; 168:725-729.

144. Henry SC. Hamilton JD. Detection of murine cytomegalovirus immediate early 1 
transcripts in the spleens of latently infected mice. Jinfect.Dis. 1993; 167950954.

145. Bruggeman $C A$. Meyer $H$. Bosman $F$, van Boven CPA. Biology of ratcytomegalovirus infection. Intervirology $1985: 24: 1-9$.

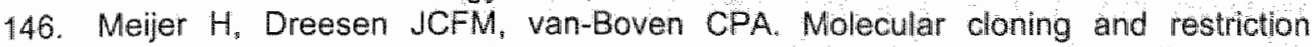
endonuclease mapping of the rat cytomegalovirus genome. J.Gen. Virol: 1986; $67: 1327-1342$.

147 Beuken $E$, Slobbe $R$, Bruggeman CA, Vink C. Cloning and sequence analysis of the genes encoding DNA polymerase, glycoprotein $B, I C P 18.5$ and major DNAbinding protein of rat cytomegalovirus. J.Gen. Virol. 1996; 77:1559-1562.

148 Vink $C$. Beuken $E_{\text {. }}$ Bruggeman $C A$. Structure of the rat cytomegalovirus genome termini. J.Virol. 1996; 70 :

149. Bruggeman CA, Reactivation of latent CMV in the rat. Transplant.Proc. 1991; 23:22-24.

150. Bruning $\mathrm{JH}$, Bruggeman $\mathrm{CA}_{\|}$van-Boven $\mathrm{CPA}_{\text {, }}$ van-Breda-Vriesman PJ. Passive trasnfer of cytomegalovirus by cardiac and renal organ transplants in a rat model. Transplantation 1986; 41:695-698.

151. Bruning $\mathrm{JH}$, Bruggeman CA, van-Boven CPA, van-Breda-Vriesman PJ. Reactivation of latent rat cytomegalovirus by a combination of immunosuppression and administration of allgeneic immunocompetent cells. Transplantation 1989; 47:917918. 


\section{CHAPTER 3}

The presence of cytomegalovirus nucleic acids in arterial walls of atherosclerotic and non atherosclerotic patients

M.G.R. Hendrix

P.H.J. Dormans

P. Kitslaar

F. Bosman

C.A. Bruggeman

American Journal of Pathology 1989; 134:1151-1157. 


\section{Abstract}

The presence of cytomegalovirus (CMV) nucleic acids was demonstrated in abdominal aorta's and femoral arteries of patients with and without atherosclerosis by dot-blot and in situ DNA hybridization using a DNA probe derived from immediate early genomic regions. Viral antigens could not be detected by immunohistochemistry and infectious virus could not be recovered from the arterial wall by virus isolation techniques. The high percentage (55\%) of vascular wall specimen containing CMV nucleic acids, in atherosiclerotic as well as in control material and the location of CMV containing cells in arteries without gross changes indicative of atherosclerosis suggest that the human arterial wall may be a site of latency for this virus.

\section{Introduction}

Infections with cytomegalovirus (CMV), a member of the herpesvirus group, are common. A characteristic feature of these viruses is that they persist in the host after primary infection and frequently reactivate from this latent state. This is clearly demonstrated in renal transplant recipients who almost invariably show evidence of active CMV infection (1).

Recently, several reports have suggested a role for CMV in the etiology of atherosclerosis. Studies in an animal model (chicken) have shown that infection with Marek's disease virus (MDV), a herpes virus, results in an extensive atherosclerosislike disease in normocholesterolemic chickens. Using in situ DNA hybridization techniques it was possible to show that MDV nucleic-acid sequences are present in the arterial walls of the infected chickens (2).

In humans the presence of herpes wiruses in the arterial wall was also demonstrated by DNA in situ hybridization and immunohistochemical techniques. Benditt and coworkers (3) detected herpes simplex virus (HSV) by in situ DNA hybridization of aortic wall specimens obtained from patients undergoing coronary bypass surgery. Melnick et al. (4) described the presence of CMV antigens in smooth muscle cells cultured from tissues obtained from patients undergoing endarterectomy or coronary bypass surgery. Four years later these findings were confirmed by the same group using in situ DNA hybridization techniques (5). Recently the presence of HSV and CMV in the coronary arterlies and thoracic aortas of young trauma victims without overt heart disease could be demonstrated by in situ DNA hybridization and immunohistochemical techniques (6). Most of these reports focus on the presence of CMV in arterial tissues obtained from patients with symptomatic atherosclerotic disease of the coronary and/or carotid arteries. It remains possible that the presence of CMV nucleic acids in atherosclerotic arterial walls reflects a site of latency as proposed by others $(4,5,6)$ and that the virus will also be present in healthy arterial vessels.

In this report we describe the presence of CMV in arterial wall tissues in patients with overt atherosclerosis as well as trauma vilctims and patients without visible atherosclerosis at autopsy. In this study virus isolation, immunohistochemistry and DNA hybridization techniques with a probe derived from Immediate Early genomic regions were used.

\section{Materials and methods}

\section{Patients and controls}

To study the presence of CMV in the arterial wall, tissue samples were obtained from the femoral artery or abdominal aorta of CMV-seropositive patients undergoing recon- 
structive vascular surgery for atherosclerotic disease. The patients received femoropop. liteal bypass grafts or synthetic bifurcation grafts. Controls consisted of CMV-seropositive patients on whom autopsy was performed. Only patients dying of non-atherosclerotic disease and with maximally grade I atherosclerosis of the aorta as shown at autopsy were included. In addition, a small group of controls consisting of young trauma victims available for donor nephrectomy, were included in this study. In the control groups, tissue samples were obtained from the abdominal aorta.

\section{Virus isolation}

A $10 \%$ (wt/vol) homogenate of arterial wall specimens was inoculated onto monolayers of diploid human embryonic fibroblasts (HEF. Flow 2002). Inoculation was performed under a centrifugal force of $1000 \mathrm{~g}$ for 1 hour at $37^{\circ} \mathrm{C}$. Subsequently, cultures were placed on maintenance medium consisting of Eagle's minimal essential medium (MEM. Gibco, Grand Islands, NY) containing $10 \%$ fetal calf serum (FCS, Gibco) and antibiotics. The cultures were incubated at $37^{\circ} \mathrm{C}$ and examined microscopically twice weekly during a period of 5 weeks for the development of a cytopathologic effect (CPE). After 1 and 5 weeks the presence of viral antigens in the monolayer was analyzed using the indirect immunofluorescence technique. For the detection of virall antigens monoclonal antibodies (Dupont, Wilmington, DE) directed against CMV immediate early antigens (IEA) were used.

\section{Fixation of tissues}

Arterial tissues for in situ hybridization were fixed in a modified Carnoys solution containing $73.5 \%$ absolute ethanol, $24.5 \%$ glacial acetic acid, and $2 \%$ formaldehyde $\left(37 \%\right.$ ). After overnight incubation at $4^{\circ} \mathrm{C}$ the tissues were rehydrated by successive 30 minute washes in graded alcohols $(100,95,85,80$ and $70 \%$ ethanol, respectively). Final storage of specimens was in $70 \%$ ethanol at $4^{\circ} \mathrm{C}$. Arterial specimens for dot-blot hybridization were finally minced, placed in RPMI-1640 (Gibco) medium and an equal volume of $95-100 \%$ ethanol was added slowly under gentle agitation. Fixed tissues were stored at $4^{\circ} \mathrm{C}$ in $50 \%$ ethanol.

\section{Monoclonal antibodies}

Monoclonal antibody 488 directed against immediate early antigens of CMV, prepared following standard procedures, was used in this study. The method employed for producing hybridomas secreting CMV antibodies have been described for rat CMV (RCMW) in detall previously (7). Briefly, BALB/C mice were immunized with sonicated suspension of CMV strain AD169 infected HEF. After 4 weeks their spleen cells were fused with mouse myoloma cells of the SP $210 \mathrm{Ag}-14$. Hybrid cells were selected in hypoxanthine-aminopterin-thymidine medium and CMV antibody producing clones were identified by enzymelinked immunosorbent assay and indirect immunofluorescence staining on CMV infected HEF monolayers as described previously for RCMV (7). Selection of the clones producing antibodies to the immediate early (IE) antigens of CMV were done using infected HEF blocked with cycloheximide and actinomycin D to only induce immediate early antigens (12).

Monoclonal antibody $H 88$ which selectively precipitates a $68 \mathrm{KD}$ protein from infected fibroblasts was used in this study. This monoclonal antibody gives a uniform nuclear fluorescence in CMV infected fibroblasts within as little as $12 \mathrm{~h}$ after infection. No cross reactivity with other herpes viruses could be detected. High titer mouse ascitic fluid was produced by infecting the antibodyproducing clone intraperitoneally into pristane treated mice.

\section{Immunohistochemistry}

Thin tissue sections of approximately $4 \mu \mathrm{m}$ mounted on glassslides were deparaffinized 
and washed in $90 \%$ ethanol. followed by blocking of endogenous peroxidase activity by incubation in $100 \%$ methanol with $0.3 \% \mathrm{H}_{2} \mathrm{O}_{2}$ for $30 \mathrm{~min}$.

The sections were then washed in phospate-buffered saline (PBS), preincubated with PBS containing $2 \%$ Bovine Serum Abumin (BSA) for 30 minutes, followed by incubation for 60 minutes with one of the mouse McAb's, washed again in PBS for 5 minutes, followed by incubation with biotinylated affinity purified sheep anti-mouse $1 \mathrm{~g}$ (Amersham) 1:200 in PBS containing 2\% BSA for 60 minutes, and washed again for 5 minutes in PBS followed by incubation with Biotin Streptavidin HRP-complex (Amersham) 1:400 in PBS containing $2 \%$ BSA for 45 minutes.

After washing again in PBS the sections were incubated for 10 minutes in diaminobenzidine-4HCl-substrate $0.05 \%$ in Tris- $\mathrm{HCl}$ buffer $\mathrm{pH} 7.4$, containing $0.002 \% \mathrm{H} 2 \mathrm{O} 2$. The color reaction was stopped by washing in $\mathrm{PBS}$, followed by counterstaining for 1 minute in hematoxylin, dehydration and mounting in Entellan (Merck, Darmstadt, FRG).

\section{A 0 10}

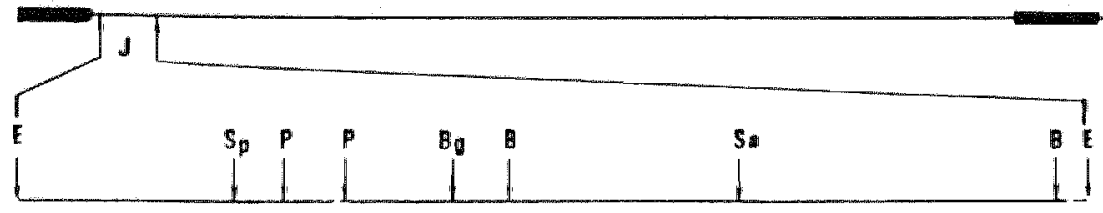

p $\mathbf{J}$

$$
1
$$

1

-

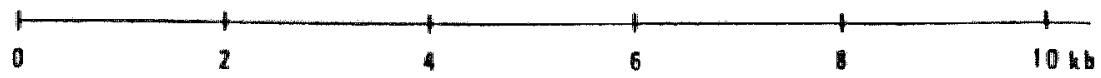

Fig. 1 Restriction endonuclease cleavage map of the cloned EcoR 1-d tragment, and the subcloned $7.0 \mathrm{~kb}$ pES fragement. The topline represents the $236 \mathrm{~kb}$ genome of HCMV strain AD169 and shows the location of the EcoR 1-J fragment in the prototype orientation. pES indicates the cloned EcoR1-J-Sal1 fragment. $\mathrm{P}(\mathrm{PV}$ UII); $\mathrm{E}(\mathrm{EcoR} 1) ; \mathrm{B}(\mathrm{BamH})) ; \mathrm{Bg}(\mathrm{Bg} / 1)$; Sa(Sal1); Sp(Sph1) represent the restriction sites present in the pES fragment.

\section{DNA probes}

Plasmid PBR 328 containing the $7.0 \mathrm{~Kb}$ ES fragment, an EcoR1-Sal1 subdigestion of the EcoRI-J Fragment of CMV strain AD 169 (Fig. 1) was provided by Dr. J. Geelen. University of Amsterdam, The Netherlands. Plasmid was transfected into an Escherichia coli mutant J.M. 109 and pure ES fragment DNA was recovered using standard procedures (8). Controls consisted of total CMV strain AD 169 DNA, total rat cytomegalovirus (RCMV) DNA (9), and plasmid pBR 328 DNA without inserts. In all DNA bilotin was inserted by incorporation of biotin-11-dUTP (Bethesda Research Laboratories, Bethesda, MD) using a random primed DNA labeling kit (Boehringer). The specificity of the biotinylated DNA probes was evaluated in uninfected HEF, HEF infected with CMV laboratory strain $\mathrm{AD} 169$, and in arterial samples using both dot blotting and in situ hybridization procedures. The in situ hybridization procedures also were performed without DNA probes to evaluate non-specific reactions.

\section{Dot blot hybridization}

Extraction of cellular DNA was performed essentially as described previously (10). After extensive washings the ethanol fixed tissues were digested overnight at $50^{\circ} \mathrm{C}$ in a 
mixture containing $10 \mathrm{mM}$ Tris-HCl, pH 7,5, $5 \mathrm{mM}$ EDTA, $100 \mathrm{mM} \mathrm{NaCL}, 0,2 \mathrm{mg} / \mathrm{ml}$ proteinase $K$ (Boehringer), and $10 \mathrm{mg} / \mathrm{ml}$ SDS. Proteins were removed using successive phenol-chloroform and chloroform extractions and DNA was recovered by ethanol precipitation. RNA was digested by incubating the precipitate during 30 min at $37^{\circ} \mathrm{Cin}$ a mixture of $10 \mathrm{mM}$ Tris-HCl, $\mathrm{pH} 7,5,1 \mathrm{mM}$ EDTA and 75 pg RNAse A (Sigma Chemical Co., St. Louis, MO). DNA was again ethanol precipitated, air dried, and redissoved in distilled water. DNA was quantified by spectrophotometry at 260 and $280 \mathrm{~nm}$. For hybridization 5-10 $\mu \mathrm{g}$ DNA (NaOH denatured) was spotted onto nitrocellulose paper (BA 85 , Schleicher and Schull). After incubation at $80^{\circ} \mathrm{C}$ for 2 hours filters were prehybridised for 4 hours at $42^{\circ} \mathrm{C}$ in a mixture containing $50 \%$ delonised formamide, $5 x \mathrm{SSC}, 5 \mathrm{x}$ Denhardt's solution, $25 \mathrm{mM}$ sodium phosphate buffer, $\mathrm{pH} 6,5$, and $0,5 \mathrm{mg} / \mathrm{ml}$ heat denatured herring sperm DNA. After this period the prehybridization solution was replaced with $150 \mathrm{ng} / \mathrm{ml}$ heat denatured dUTP probe and $5 \%$ (wtvol) dextran sulphate in the same solution. Hybridization was carried out at $42 \mathrm{~B}^{\circ} \mathrm{BC}$ for 12 hours in a roller drum at 1 to 2 rpm. Filters were washed in two changes of $2 \times \mathrm{SSC}, 0,1 \% \mathrm{SDS}$ at room temperature for 5 minutes each, twice in $0,2 \times \mathrm{SSC}, 0,1 \%$ SDS at room temperature for 5 minutes each, twice in $0,16 \times \mathrm{SSC}, 0,1 \% \mathrm{SDS}$ at $55^{\circ} \mathrm{C}$ for 15 minutes each and finally once in $2 \times \mathrm{SSC}$ at room temperaturefor 1 minute. Visualisation of successful hybridization was performed with the BLU gene kit (Bethesda Research Laboratories).

The specificity of the biotinylated probes was evaluated with DNA extracted from CMV strain AD169 infected HEF and uninfected HEF spotted onto nitrocellulose paper. Only ES probe and total CMV probe showed hybridization with DNA extracted from infected HEF but not with DNA extracted from uninfected HEF. RCMV and plasmid probes did not show hybridization.

\section{In situ hybridization}

Arterial specimens fixed in a modified Carnoy's solution were embedded in paraffin blocks using routine histopathologicalprocedures. Sections 3 to $4 \mu \mathrm{m}$ thick were cut from these blocks and placed on chromium-alum-gelatin coated and glutaraldehyde activated slides (11). After overnight incubation at $52-54^{\circ}$ sections were dewaxed in xylene, washed once in $100 \%$ ethanol and air dried.

Aldehyde groups were inactivated by incubating the slides with $1 \%$ ammoniumchloride in PBS. Proteolytic digestion with proteinase $K$ (Boehringer) $(2,5-20 \mu \mathrm{rg} / \mathrm{ml})$ in $20 \mathrm{mM}$ Tris- $\mathrm{HCl}_{1} \mathrm{pH} \mathrm{7,4}$ containing $2 \mathrm{mM} \mathrm{CaCl}_{2}$ was carried out for 30 minutes at $37^{\circ} \mathrm{C}$ and the reaction was subsequently stopped by washing the slides with PES containing $2 \mathrm{mg} / \mathrm{ml}$ glycine. Slides were then dehydrated by successiwe washings in graded alcohols (30, $60,80,95$ and $100 \%$ ethanol respectively) and air dried. When needed, RNA digestion was carried out by incubating the slides with $100 \mu \mathrm{g} / \mathrm{ml}$ RNAse A ((Sigma) in PBS at $37^{\circ} \mathrm{C}, 1$ hour and the reaction was stopped by 2 successive washings in PBS. Slides were again dehydrated by successive washings in graded alcohols. Immediately after these pretreatment steps, samples were overlaid with $48 \%$ deionised formamide, $10 \%$ dextran sulphate, $5 \times$ SSC, $5 \times$ Denhard's solution, $50 \mathrm{mM}$ sodium phosphate, pH 6.4, 0,1 $\mu \mathrm{g} / \mathrm{ml}$ herring sperm DNA, and $200 \mu \mathrm{g} / \mathrm{ml}$ probe DNA covered with a silicon-coated coverslip and sealed with rubber cement. Cellular and probe DNA were denatured by heating the slides to $83^{\circ} \mathrm{C}$ and immediately immersing them in ice-cold water. Hybridizalion was carried out overnight at $42^{\circ} \mathrm{C}$. Washing procedures and visualisation of formed hybrids was performed as described for dot blot hybridization.

The specificity of the biotinylated probes was evaluated on CMW strain AD169 infected HEF monolayers and on uninfected HEF monolayers. Only ES probe and total CMV probe showed hybridiza;tion with infected HEF monolayers, but not with uninfected HEF monolayers. RCMV and plasmid probes never showed hybridization. 


\section{Statistical analysis}

Statistical analysis was carried out using Fisher's exact tests. Results were considered significant when $p<0,01$.

\section{Results}

\section{Patients and controls}

Tissue samples were obtained from 44 patients undergoing vascular surgery (Table 1). Twenty-two samples were taken from the abdominal aorta ( 20 men, 2 women) and 22 samples were taken from the femoral artery ( 10 men, 12 women). The mean age of these patients was 66 years. Controls consisting of eight trauma victims ( 6 men, 2 women) with a mean age of 32 years were used. Arterial samples were taken from the abdominal aorta during donor nefrectomy.

The autopsy-control series contained 23 patients ( 10 men, 13 women) with a mean age of 69 years. The abdominal aorta samples were taken within 12 hours after death. Mean ages of the atherosclerotic and autopsy control group were in the same range, as was the distribution among the sexes. Statistical analysis of these data showed no significant differences, so the groups were suitable for comparison. The mean age of the trauma victim group, however, was too llow for comparison.

Table 1. Characterlstics of pattents series under investgation

\begin{tabular}{|c|c|c|c|c|c|}
\hline Pattutes & Boposies & $\begin{array}{c}\text { Mean age } \\
\text { (years } \\
\text { SDI }\end{array}$ & $\begin{array}{l}\text { Range } \\
\text { (years) }\end{array}$ & Men & Women \\
\hline $\begin{array}{l}\text { Grade III atherosde- } \\
\text { rosis. }\end{array}$ & Fimarat artery & $70 \pm 9.5$ & 55868 & $10(45 \%)$ & $12(55 \%)$ \\
\hline (Alurgical pattents) & $\begin{array}{l}\text { Abdortinal aorta } \\
\text { Abdomthual aorta }\end{array}$ & $\begin{array}{l}62 \pm 10.0 \\
69+13.6\end{array}$ & $\begin{array}{l}44-80 \\
45-91\end{array}$ & $\begin{array}{l}20(90 \%) \\
10\left(43^{9} \%\right)\end{array}$ & $\begin{array}{r}2(10 \%) \\
13(57 \%)\end{array}$ \\
\hline $\begin{array}{l}\text { No almeroscterosis } \\
\text { (aulopsy) } \\
\text { Trauma witims }\end{array}$ & Abcompingt aor & $32 \pm 180$ & $g_{2} 60$ & $0(75 \%)$ & $2(25 \%)$ \\
\hline
\end{tabular}

\section{Virus isolation}

Virus isolation experiments were performed on fresh arterial samples only. In none of the tested samples was a cytopathological effect (CPE) observed in the HEF monolayers during a 5-week period. Using the indirect immunofluorescence technique with monoclonal antibodies directed against CMV, immediate early antigens (IEA) viral proteins were not detected in the HEF monolayers, indicating the absence of infectious virus.

\section{Immunohistochemistry}

Immunohistochemical studies were performed on all arterial samples. Immunoreactivity was not observed in any of the tested samples using McAbs against IEA.

\section{Dot blot hybridization}

Using the dot blot hybridization technique (Table 2) CMV nucleic acid sequences were detected in 4 of $22(18 \%)$ samples of the femoral artery and in 7 of $22(32 \%)$ samples of the abdominal aorta of patients with severe atherosclerosis. Statistical analysis revealed this difference between the two groups to be not significant $(p<0,447)$. By evaluating the extracted DNA in the samples obtained from the abdominal aorta of patients without signs of atherosclerosis, CMV nucleic acid sequences were detected in 5 of $23(22 \%)$ cases, which is not statistically different from the atherosclerosis samples $(p<0,479)$. Of samples from trauma victims, 4 of $8(50 \%)$ were positive for CMV DNA 
but this group was too small for statistical analysis.

Thus, we could conclude that $30 \%$ of the samples tested contained CMV nucleic acids using this technique.

Tabie 2. Results of dot biot and in situ DNA hybridtation af arterial tissues

\begin{tabular}{|c|c|c|c|}
\hline Petients & Bopsies & $\begin{array}{l}\text { Cilly hybridization } \\
\text { dol blot number positive } \\
\text { total number (wo) }\end{array}$ & $\begin{array}{c}\text { Chu hybridization } \\
\text { in silu number positue } \\
\text { tolut number }(\%)\end{array}$ \\
\hline \multirow{2}{*}{$\begin{array}{l}\text { Grade ill atheroscierosis } \\
\text { (surgical patients) }\end{array}$} & Femoral artery & $4 / 22(18 \%)$ & $922(41 \%)$ \\
\hline & Abdominal arora & $7 / 22(32 \%)$ & $1022(45 \%)$ \\
\hline $\begin{array}{l}\text { No atherosclenosis } \\
\text { (autopsy) }\end{array}$ & Abdominal aora & $523(22 \%)$ & $17 / 22(79)$ \\
\hline Tratuma victims & Atodominal aorla & $48(50 \%)$ & 58 (63\%) \\
\hline
\end{tabular}
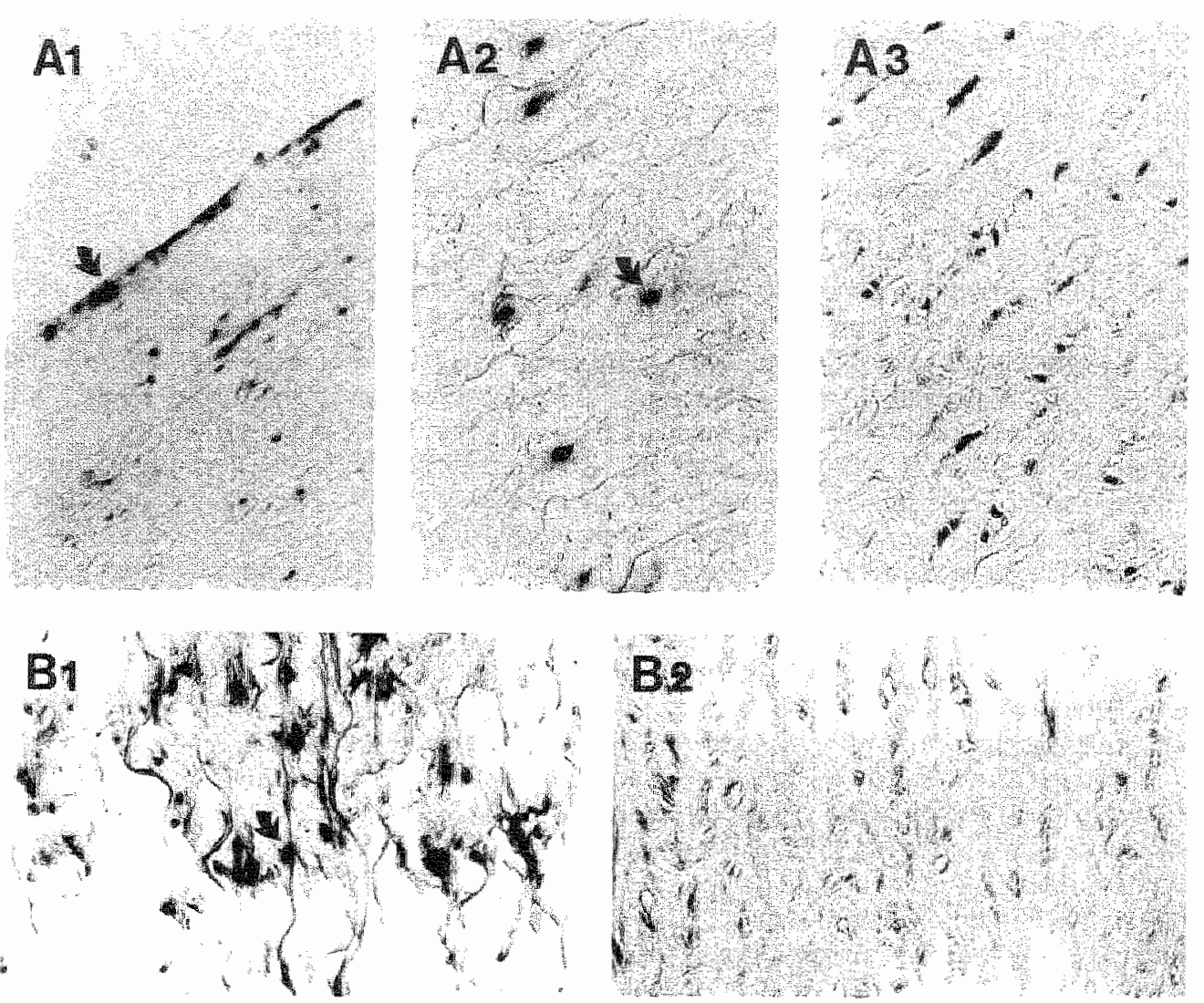

Figure 11

Photomicrographs of in silu hybridization of sectons of anterial wals using CMVspecific probes and haemoloxylin-eosin (H\&E) staining ofsequential sections of arterial walls of wo patienis ( $A$ and $B$ ). $A_{1} 1$ : An $_{2}$ in situ hybridization of the thitima and media of an arterial wall. The dark spots (arrow) represent the hybridization (100k). A2: Magnification of A1 showing discrete nuclear hybridization (250x). A3: swuential section of A2, stained with H\&E, showing a normel anterial architecture. B1: Anohier example of an in situ hybridization. Q2: Sequential seclon stained with H\&E (520x) 
In siu DWA hybridization (Fig. 2) of sections of arteries obtained from patients with severe atherosclerosis showed that 9 of $22(41 \%)$ biopsies of femoral arteries and 10 of $22(45 \%)$ biopsies of abdominal aortas contained CMV nucleic acid sequences; statisticall analysis showed no significant differences beween these groups $(p<0,220)$. Evaluation of the samples of the abdominal aorta of patients without atherosclerosis at autopsy revealed that 17 of $22(77 \%)$ contained CMV DNA, which is not statistically different $(p<0,240)$ from the group with atherosclerosis. Five of $8(63 \%)$ samples obtained from the abdominal aorta of trauma patients were positive for CMV nucleic acids. However, the number of trauma victims was too small for statistical analysis. Thus, we could conclude that $55 \%$ of the samples tested contained CMV nucleic acids using this technique.

Tissue samples that showed extensive in situ hybridization reactivity were analyzed further by RNA digestion before in situ DNA hybridization. After RNAse treatment the tissue sections showed a less intense hybridization reaction, and in some cases the reactivity disappeared altogether.

Histologically, the CMV nucleic acid sequences detected with the ES probe were located mainly in apparently normal arterial tissue without an inflammatory reaction or atheromatous changes. Sequential sections, stained with haematoxilin and eosin, showed that the DNA hybridization reactivity was located mainly in smooth muscle cells in the arterial media.

\section{Discussion}

This study has demonstrated the presence of CMV nucleic acid sequences in biopsies of femoral arteries and abdominal aortas of atherosclerosis patients as well as controls. CMV nucleic acids were distributed equally among patients with and without this disease. No differences were observed in CMV distribution between biopsies taken from femoral arteries or from abdominal aortas.

The percentage of samples containing CMV nucleic acid $(30 \%)$ by dot blot hybridization techniques equals the percentage found by others using in situ DNA hybridization techniques $(5,6)$ or by immunohistochemistry $(4)$. Using in situ hybridization, however, we found that a considerably higher percentage $(55 \%)$ of the samples investigated contained CMV nucleic acids. There are two possible explanations for this phenomenon: Firs, our in situ DNA hybridization technique did not include RNase treatment of the tissue sections. It is therefore likely that the probe DNA formed not only DNA.DNA hybrids but also RNA-DNA hybrids (11). The finding that tissue samples that showed extensive in situ hybridization reactivity showed a less intense hybridization reaction and in some cases became negative after RNAse treatment seems to corroborate this possibility. It is therefore likely that in situ mRNA.DNA hybrids contribute significantly to the obtained reactivity. In contrast, extraction of DNA for dot blof hybridization always included RNase treatment and consequently only the samples sufficiently rich in viral IDNA showed hybridization reactivity using this technique.

Second, in our view the most likely explanation of the observed difference is the choice of the CMV DNA probe, which was prepared from the EcoR1-J fragment of CMV strain AD 169, containing sequences coding for immediate early transcripts (12) (Fig. 1). Recently, latency associated transcripts (LAT) were described in neurons during latent Herpes Simplex Virus (HSV) infection (14, 15), originating from genomic regions coding for immediate early transcripts of HSV (16, 17, 18). These HSV mRNA transcripts could be detected by DNA probes prepared from the immediate early genomic regions (14). In CMV the immediate early transcripts might therefore not only be transcribed during reproductive viral cycles (13), but also during latent infections. The high percentage 
(55\%) of arterial samples containing CMV nucleic acids in this sudy can therefore be explained by the use of the ES probe, because in other studies $(5,6)$ probes coding for nonimmediate early regions were used. Together with the negative results from the wirus isolation and the negative results from the immunohistochemical studies, we conclude that the arterial wall may be a site of latency for CMV, as already proposed by others $(4,5,6)$.

Although the present results do not suggest a direct role for CMV in the pathogenesis of atherosclerosis, the presence of (latent) wirus in the vessel wall might constribute to the process of atherogenesis. The ability to reactivate from the latent status leading to a local lytic infection in the vessel wall might result in repeated local inflammatory reactions eventually leading to vascular injury. This injury, in cooperation with other established risk factors, could play a still unknown role in atherogenesis.

Further studies are needed to elucidate the factors leading to reactivation of the CMV and the development of atherosclerosis as a consequence of a local productive infection.

\section{References}

1. Ho m. Cytomegalovirus biology and infection. New York, Plenum Press, 1982

2. Fabricant $C G$, Fabricant J Milnick $C R$, Litrenta MM. Herpesvirus-induced atherosclerosis in chickens. Fed.Proc. $1983 ; 42,2476-2479$

3. Benditt EA, Barret T, McDougall JKK. Viruses in the etiology of atheroscilerosis. Proc Natl Acad Sci USA 1983: 6386-6389.

4. Melnick JL, Petrie BL, Dreesman GR, Burek J, McCollum CH, Debakey ME. Cytomegalovirus antigen within human arterial smooth muscle cells. Lancet 1983. 2: 644-647.

5. Petrie BL, Melnick JL, Adam E, Burek J, McCollum CH, Debakey ME. Nucleic acid sequence of cytomegalovirus in cells cultured from human arterial tissue. J Infect Dis 1987, 155: 158-159.

6. Yamashiroga HM, Ghosh L, Yang R, Robertson L. Herpes viridae in the coronary arteries and aorta of young trauma victims. Am J Path 1988, 130: 71-79.

7. Bruning IH, Debie WHM. Dormans PHJ, Meijer H, Bruggeman CA. The development and characterization of monoclonal antibodies against rat cytomegalovirus induced antigens. Arch.Virol. 1987:94:55-70.

8. Birnboim HC. Doly J. A rapid alkaline extraction method for the isolation of plasmid DNA. Nucl Acid Res 1979, 7: 1513-1518.

9. Meyer H. Dreesen JCFM, van Boven CPA. Molecular cloning and restriction endonuclease mapping of rat cytomegalovirus genome. \Gen Virol 1986, 67: 1327-1342.

10. Smith Lل, Braylan RC. Natkis JE, Edmunsun KB, Downing JR, Wakeland EK. Extraction of celletar DNA from human cells and tissues fixed in ethanol. Anal.Biochem. 1987;:160:135-138.

11. Deatly AM, Spirack JG, Lavi E, Fraser NW. RNA from an immediate early region of the type I herpes simplex virus genome is present in the trigeminal ganglia of latently infected mice. Proc. Natl.Acad.Sci.USA 1987;84:3204-3208.

12. Boom R. Repression and activation of the human cytomegalovirus major immediate early transcription unit. PhD Thesis. Rodopi Press, Amsterdam, 1987.

13. Stinski MF, Thomsen DR, Stenberg RM, Goldstein LC. Organization and expression of the immediate early genes of the human cytomegalovirus. J Virol 1983. 46: $1-14$.

14. Stevens JG, Haar L, Porter DD, Cook ML. Wagner EK. Prominence of the Herpes Simplex virus latency associated transcript in trigeminal ganglia from seropositive 
humans. J Infect Dis 1988, 158: 117-123.

15. Croen KD, Ostrove JM, Dragovic LJ, Smialek JE, Straus SE. Latent Herpes Simplex virus in human trigeminal ganglia. N Engl J Med 1987, 23: 1427-1432.

16. Wagner EK, Devi-Rao G. Feldman LT, Dobson AT, Zhang $Y$, Flanagan WM, Stevens JG. Physical characterization of the Herpes Simplex virus. Latencyassociated transcript in neurons. J Virol 1988, 62: 1194-1202.

17. Deatly AM, Spivack JG, Lavi E, O'Boyle II DR, Fraser NW. Latent herpes simplex virus type 2 transcripts in peripheral and central nervous tissues of mice map to similar regions of the viral genome. J.Virol. 1988;62:749-756.

18. Gordon $Y L$, Johnson $B$, Romanowski $E$, Araulo-Cruz T. RNA complementary to herpes simplex type I ICPO gene demonstrated in neurons of human trigeminal ganglia. J.Virol. 1988;62:1832-1835. 


\section{CHAPTER 4}

\section{High prevalence of latently present cytomegalovirus in arterial walls of patienst suffering from grade III atherosclerosis}

M.G.R. Hendrix

M.M.M. Salimans

C.P.A. van Boven

C.A. Bruggeman

American Journal of Pathology 1990; 136:23-28. 


\section{Abstract}

The presence of Cytomegalovirus (CMV) nucleic acids was demonstrated in arterial walls of patients with grade III and with maximally grade $\|$ atherosclerosis by dot blot and in situ DNA hybridization and by polymerase chain reaction (PCR) Using probes and primers derived from Immediate Early (IE) and Late (L) genomic regions. The presence of the complete viral genome could be demonstrated by both dot blot DNA hybridization and PCR. IE MRNA but not $L$ MRNA could be demonstrated by in situ DNA hybridization, indicating the presence of latent CMV in the human arterial wall. By PCR $90 \%$ of the samples obtained from atherosclerotic patients were shown to contain viral nucleic acids as compared to $53 \%$ of patients with maximally grade I atherosclerosis, thus substantiating a role for this wirus in the pathogenesis of atherosclerosis.

\section{Introduction}

Recently several investigators were able to demonstrate the presence of Cytomegalovirus (CMV) nucleic acids and/or antigens in the human arterial wall by using DNA hybridization techniques (1) or immunohistochemistry (2). Most arterial specimen were taken from patients undergoing reconstructive vascular surgery for severe atherosclerotic disease, and so a role for the CMV in the pathogenesis of this disease was indicated (3). On the basis of these observations it was suggested that the human arterial wall might be a site of latency for the CMV $(1,2,4)$. Lacal reactivation of this virus could then lead to vascular injury and consequently contribute to the development of atherosclerotic lesions. However, the studies published did not include an age and sex matched control group of patients with minimal or no signs of atherosclerosis.

In our laboratory we demonstrated the presence of CMV nucleic acids in the human arterial wall (5) by Dot blot and in situ DNA hybridization techniques. We didn't, however, observe any differences in the distribution of CMV nucleic acids in samples of patients with severe atherosclerosis or patients with maximally grade I atherosclerosis. A possible explanation for this observation is the relative insensitivity of the methods used. Only samples that were sufficiently rich in viral nucleic acids could be detected. More sensitive methods might still show a difference in the distribution of the virus among the patient groups investigated.

Using in situ DNA hybridization with a probe derived from Immediate Early (IE) genomic regions demonstrated that $50 \%$ of the samples lested contained CMV nucleic acids; which is considerably higher (5) than the percentages found by other researchers using various DNA probes (1, 3). We showed that mRNA-DNA hybrids contributed significantly to the hybridization reactivity observed. This finding that $55 \%$ of the arterial samples tested with the ES probe contained CMV nucleic acids shows that mRNA transcribed from $\| E$ genomic regions are not only present during reproductive viral cycles (6) but also during latent infections.

In this report we provide further evidence that the CMV is latently present in the human arterial wall by in situ DNA hybridization with a probe derived from genomic regions coding for structural proteins. We show also that the complete viral genome is conserved in the arterial wall by dot blot DNA hybridization and Polymerase Chain Reaction (PCR). Using the PCR we found that the prevalence of CMV nucleic acids in patients suffering from severe atherosclerosis is significantly higher than in patients with maximally grade / atherosclerosils. 


\section{Materials and methods}

\section{Patients and controls}

The subjects of this study were as described previously (5). In brief, arterial biopsies were taken from CMV-seropositive patients undergoing reconstructive vascular surgery. Biopsies were taken from the abdominal aorta or from the femolal antery. CMV-seropo. sitive controls consisted of age and sex matched patients with maximally grade I atherosclerosis as shown at autopsy. In this group biopsies were taken from the abdominal aorta. Autopsy was always performed within 12 hours after death.

In additional to our previous study, we increased the number of patients entering the control group.

\section{Processing of tissue specimens}

Arterial tissues for in situ and dot blot hybridization and for polymerase-chain reaction were processed as reported previously (5). For in situ DNA hybridization, tissue specimen were incubated overnight in a modified camoy"s solution, dehydrated by successive washes in graded alcohols, and embedded in paraffin, using routine histopathological procedures. For dot blot hybridization and PCR, DNA was extracted from the arterial specimen by proteolytic digestion and phenol-chloroform extraction followed by ethanol precipitation. DNA was quantified by spectrophotometry at 260 and $280 \mathrm{nM}$.

\section{Hybridization probes}

All enzymes were purchases from Boehringer-Mannheim (FRG). Enzyme reactions were performed under conditions recommended by the manufacturer. Recombinant plasmids were prepared by following published procedures (7) using vector pBR328.

Plasmid pES (Fig. 1) containing the 7,0 Kb ES fragment, an EcoRI-Sall subdigestion of the EcoRl-J fragment of CMV strain Ad 169, coding for the major Immediate Early (IE) protein (8) was kindly provided by Dr. J. Geelen (University of Amsterdam, the Netherlands).

Plasmid $\mathrm{pBH}$ (Fig. 1) containing the 2,9 $\mathrm{Kb}$ BH fragment, coding for the late nucleocapsid protein GP $64(9,10)$, was constructed from a Hindlll-Bam HI subdigestion of cosmid PCM 1075. This cosmid was kindly provided by Prof.Dr. A.J. van der Eb (University of Leiden, the Netherlands). Both plasmids were transfected into Escherichia coli mutant JM 109 and by standard procedures $(7,11)$ pure ES and BH DNA was recovered. Controls consisted of total CMV strain AD169 DNA, total RCMV DNA (12) and plasmid pBR328 DNA without inserts. In all DNA biotin was inserted by incorporation of biotin-11-dUTP (Bethesda Research Laboratories) using a random primed DNA labeling kit (Boehringer-Mannheim).

\section{Dot-blot hybridization}

Spotting of cellular DNA on nitrocellulose paper, hybridization conditions, and visualization of successfull hybridization were carried out as described previously (5).

The specificity of the biotinylated probes was evaluated with DNA extracted from CMV strain AD169 infected human embryonic fibroblasts (HEF) and uninfected HEF spotted onto nitrocellulose paper. Only ES probe, BH probe and total CMV probe showed hybridization with DNA extracted from infected HEF but not with DNA extracted from uninfected HEF. RCMV and plasmid probes never demonstrated hybridization. 
AD 169 (HINd II PESTPICTION MAP)

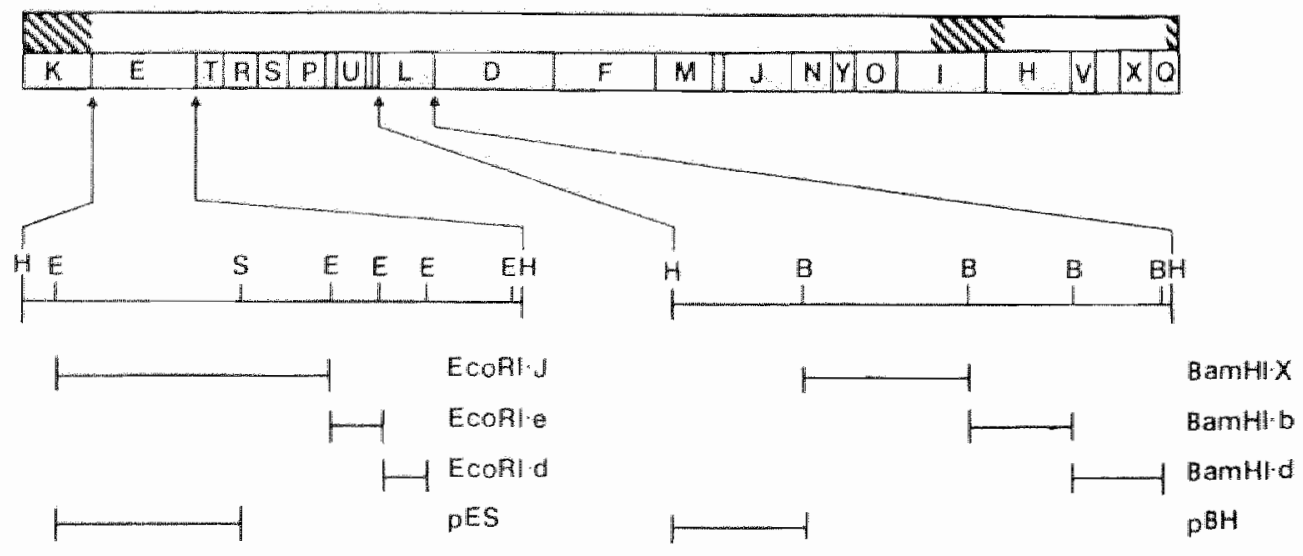

Fig. 1 Restriction endonuclease cleavage map of CNV strain AD 169. The topline represents the Hindllt digestion map in prototype arrangement: (8) showing the positions of the Hindill-E fragiment containing IE sequences and the Hind III-L fragment containing Late sequences. The left panel shows the position of the cloned ES fragment $(7,0 \mathrm{~KB})$ coding for the major $\|$ E protein $(8)$ within the Hindlli-E fragment relative to the EcoRIm, $J_{n}$ and $d$ fragments. The right panel shows the position of the cloned $\mathrm{BH}$ ragment $(2,9 \mathrm{~KB})$ coding for the late nucleacapsid protein GP $64(9-8)$ within the Hindill-L

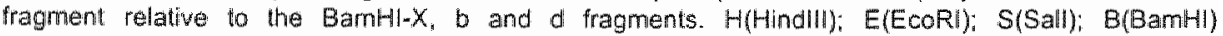
represent restriction endonuciease cleavage sites.

\section{In-situ hybridization}

The in situ DNA hybridization protocol performed on tissue sections of arterial specimen has been described previously (5). The specificity of the biotinylated probes was evaluated on CMV strain AD169 infected HEF monolayers and on uninfected HEF monolayers. Only ES probe, BH probe and total CMV probe showed hybridization with infected HEF monolayers, but not with uninfected HEF monolayers. RCMV and plasmid probes never showed hybridization.

\section{Oligomer synthesis}

The oligomers used as primers in the polymerase chain reaction (PCR) were synthesized by Dr. H. Meijer (Department of Genetics and Cell Biology. University of Limburg, Maastricht, The Netherlands) on a DNA synthesizer (cyclone DNA synthesizer. Bicsearch Inc., New Brunswick) by the fosfamidid method. The sequences for the oligomer set complementary to the major IE-gene were based on the sequence described by Akrigg et al. (13) and located in the insert of plasmid pES. The sequences are: 5-GGAGAT-GTG-GAT-GGC-TT-G-TA-3 (IE. upstream primer) and 5-GAA-GGC-TGA-GTTCTT-GGT-AA-3 (IE. downstream primer). The sequences for the oligomer set complementary to the nucleocapsid GP 64 gene correspond to published sequences (14) and are located in the insert of plasmid pBH. The sequences are 5-CCG-CAA-CCT-GGTGCC-CAT-GG-3 (LA, upstream primer) and 5-CGT-TTG-GGT-TGC-GC-A-GCG-GG-3 ( $L A_{2}$ downstream primer). The sizes of the PCR amplification products of the IE and GP 64 targets are 170 and 140 base pairs, respectively. 


\section{Polymerase chain reaction}

Amplification of extracted cellular DNA was performed in a total volume of $30 \mu$. The reaction mixture contained: $10 \mathrm{mM}$ Tris- $\mathrm{HCl}\left(\mathrm{pH}_{3} 6\right), 10 \mathrm{mM} \mathrm{MgCl}, 0.2 \mathrm{mg} / \mathrm{ml} \mathrm{BSA}$ Boseral (Organon), $50 \mathrm{mM} \mathrm{NaCl}, 1 \mathrm{mM}$ dATP, $1 \mathrm{mM}$ dCTP, $1 \mathrm{mM}$ dTTP, $1 \mathrm{mM}$ dGTP (all nucleosides purchased from Promega), $0,5 \mu \mathrm{g}$ of each primer, $1 \mathrm{U}$ cloned thermostable DNA polymerase from Thermus Aquaticus (Ampli-Taq, Perkin-Elmer-Cetus) and $2,5-5,0 \mu \mathrm{g}$ of sample DNA. The reaction mixture was overlayed with $20 \mu$ paraffin oil to prevent evaporation. The amplification reaction was performed on a DNA thermal cycler (Cetus). Each primer set was evaluated with regard to annealing temperature and the number of cycles required to achieve the highest signal-to-noise ratio when the products were evaluated by direct staining of $2 \%$ agarose (Seakem) gels. The reaction conditions that follow. were found to be optimal. After initial heating of the samples for $5 \mathrm{~min}$ at $94^{\circ} \mathrm{C}, 37$ cycles were carried out. Each cycle was built up as follows: heating for $30 \mathrm{~s}$ at $94^{\circ} \mathrm{C}$ to denature the target DNA, then cooling to $59^{\circ} \mathrm{C}$ for $45 \mathrm{~s}$ to allow the primers and DNA to reanneal, and finally heating to $72^{\circ} \mathrm{C}$ for $120 \mathrm{~s}$ for primer extension. Fifteen $\mu \mathrm{I}$ Of the reaction mixture was subjected to electrophoresis on $2 \%$ agarose (Seakem) gels containing $0,5 \mu \mathrm{g} / \mathrm{ml} \mathrm{EtBr}$. The DNA was visualized by UV fluorescence. The specificity and sensitivity of both primer sets has been tested extensively by others $(13,14)$. No cross reactivity was observed between the $\mathrm{IE}$ primer set and plasmid $\mathrm{pBH}$ nor between the LA primer set and plasmid pES.

Also no reactivity was observed when testing both primer sets on DNA obtained from HEF or from leucocytes from healthy individuals. DNA samples which didn't show reactivity with the CMV primers used were further analysed with a primer set reactive with the B-globine gene (15) to check on DNA preservation. All samples tested this way did show an 110 bp amplification product of the B-globine gene proving that DNA preservation was sufficient for PCR analysis.

\section{Statistical analysis}

Statistical analysis was carried out using Fisher's exact tests. Results were considered significant when $p<0,01$.

\section{Results}

\section{Patients and controls}

Tissue samples were obtained from 44 patients undergoing reconstructive vascular surgery (30 men, 14 women) for obstructive atherosclerotic disease. Twenty-two samples were taken from the femoral artery (10 men, 12 women) and 22 samples were taken from the abdominal aorta ( 20 men, 2 women). The mean age of all patients was 66 years (range $44-88$ ).

The autopsy-control series contained 34 patients ( 16 men, 18 women) with a mean age of 69 years (range 45-91). In this group samples were taken from the abdominal aorta within 12 hours after death.

Mean ages of atherosclerotic and autopsy-control group were in the same range as was the distribution among the sexes.

\section{Dot blot DNA hybridization}

Using the dot-blot hybridization technique (Table 1) CMV nucleic acid sequences were detected in 11 of $44(25 \%)$ samples obtained from patients with severe atherosclerosis using the ES probe, and in 4 of $14(29 \%)$ samples of the same patient group using the $\mathrm{BH}$ probe. Statistical analysis revealed this difference between the two probes was not significant $(p=0.5214)$.

By evaluating the extracted DNA of the samples obtained from patients with maximally 
grade atherosclerosis, CMV nucleic acids were detected in 7 of $33(21 \%)$ cases using the ES probe and in 4 of $23(18 \%)$ cases using the BH probe which was not a statistically significant difference $(p=0.5003$ ).

Also no statistical significant differences were observed in the distribution of CMV nucleic acids in samples of patients with or without atherosclerosis by using the ES probe $(p=0.4565)$ or by using the $\mathrm{BH}$ probe $(p=0.343)$.

Overall we could conclude that by using this technique $27 \%$ of the samples tested contained CMV nucleic acids regardless of the patient group or the probe used.

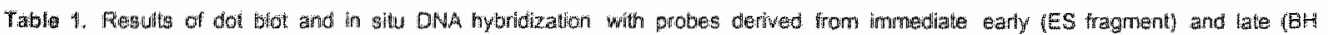

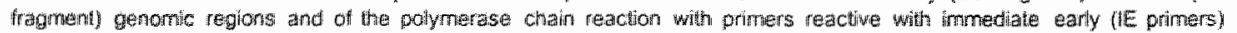
ards tste (LA phmers) ganomic sequences.

\begin{tabular}{|c|c|c|}
\hline 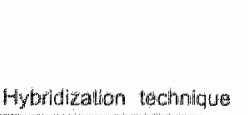 & $\begin{array}{c}\text { Grade Ill } \\
\text { ahnerosclerosis } \\
\text { Nr. POS } \\
\text { totall nr. (\%) }\end{array}$ & $\begin{array}{c}\text { Max grade } \\
\text { atherosclerosibs } \\
\text { Nr. POS } \\
\text { Hotal nr. (\%o) }\end{array}$ \\
\hline \multicolumn{3}{|l|}{ Dot bitet mybridization } \\
\hline ES fragment & $14 \sqrt{44}(25 \%)$ & $7 / 33(21 \%)$ \\
\hline BH fragment & $4144(29 \%)$ & $2 / 23(18 \%)$ \\
\hline \multicolumn{3}{|l|}{ In silu bybridization } \\
\hline Es lragrwent & $10 / 41(44 \%)$ & $19 / 33 \quad(58 \%)$ \\
\hline BH fragment & $5 \% 4(12 \%)$ & $5 / 33(15 \%)$ \\
\hline \multicolumn{3}{|l|}{ Polymerase chain reaction } \\
\hline "E prinuers & $27 / 30(90 \%)$ & $18 / 34(53 \%)$ \\
\hline LA primers & $27 / 30(90 \%)$ & $80434(53 \%)$ \\
\hline
\end{tabular}

\section{In situ DNA hybridization}

In situ DNA hybridization (Table 1) of sections of arteries obtained from patients with severe atherosclerosis showed that 18 of $41(44 \%)$ contained CMV nucleic acids by using the ES probe. However, by using the BH probe only 5 of 41 (12\%) samples obtained from the same patient group were shown to contain CMV nucleic acids. The differences found between these two probes are statistically significant $(p=0.002)$.

Evaluation of the samples obtained from patients with maximally grade 1 atherosclerosis revealed that 19 of $33(58 \%)$ contained CMV nucleic acids by using the ES probe and only 5 of $33(15 \%)$ by using the $\mathrm{BH}$ probe. The difference between these two probes was also statistically significant $(p=0.0004)$.

There was no difference in the distribution of CMV nucleic acids as demonstrated by in situ hybridization between patients with or without atherosclerosis by using the ES probe $(p=0.175)$ or by using the BH probe $(p=0.485)$.

Overall, we could conclude that $50 \%$ of the samples tested with the ES probe contained CMV nucleic acids, but by using the $\mathrm{BH}$ probe only $14 \%$ of these samples could be demonstrated to contain the Cytomegalovirus.

\section{Polymerase chain reaction}

The polymerase chain reaction performed on pure DNA extracted from arteries of patients suffering from severe atherosclerosis showed that 27 of $30(90 \%)$ contained CMV nucleic acids regardless of the primer set used (Table 1).

The samples obtained from patients without atherosclerosis showed exactly the same reactivity with regard to the primer set used. Eighteen of $34(50 \%)$ siamples were demonstrated to contain CMV nucleic acids by both primer sets, one directed against the DNA coding for the major immediate early antigen and on directed against the DNA coding for the nucleocapsid protein GP 64.

Samples reactive with the IE primer sel were also allways reactive with the LA primer set. Negative samples did not react with the IE primer set or with the LA primer set.

We observed a great difference in the distribution of CMV nucleic acids obtained from 


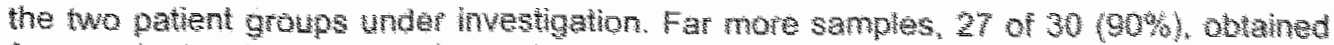

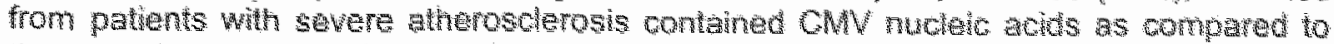

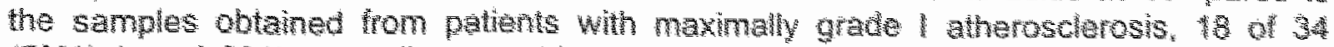

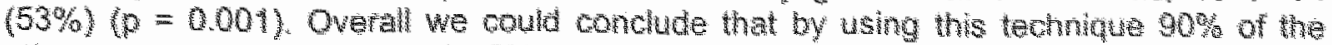

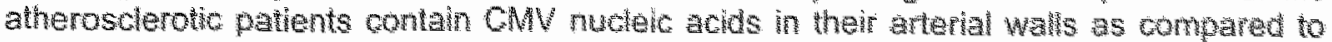
$53 \%$ of the patients wh maxhaly grade atheroscherosis, regardess of he phmat set used.

\section{Discussion}

In this study we demonstrated that he percentage of aterial specimens oblaned rom patents wh or whout atherosclerosis containing CMV nucleis acids depended highy on the DMA detection method and probes used. With a crude method like dot bot DNA hybridization only low percentages of samples $(27 \%)$ containing the virus coutd be detected, regardless of the probes used. However, by using in situ DNA hybridzaton techniques, a higher percentage of samples could be shown to contain the vira nupleic acids, depending on the probes used. Probes drected aganst IE genomic sequences gave higher yields $(50 \%)$ than probes directed against structural secuences $(12 \%)$. The sensitivity of this method, however. wasn't sufficient to detect diferences in the distribution of CMV nucleic acids between the patient groups under investigation. With a very sensitve method like the polymerase cham reaction we showed that a much higher percentage (90\%) of atherosclerotic patients contained CMV DNA in the arterial walls as compared to patents with maximally grade 1 atherosclerosis $(53 \%)$. h additon, with this method we demonstrated that both immediale early and late sequences were always simultaneously present in al the reactive samples.

As already stated (5), the percentage of samples containing CMV nucleic acids as shown by dot blot hybridzation with the ES probe (27\%) equals the percentages found by others $(1,4)$ using DNA probes derved from various genomic regions. This means that all samples containing sufficient viral DNA will show hybridization reactivity using this technique, regardiess of the probe used. An impotant conctusion that may be drawn from these findings is that the whole viral genome is present in the human arterial wall. Our finding, using dot blot hybridization techniques, that arterial wall specimen showing hybridization reactivity with the ES-probe almost always showed reactwity with the BH-probe too, further substantiates this thesis.

Using in situ DNA hybridization with the ES-probe we found a considerably higher percentage $(50 \%)$ of the samples investigated to contain CMV nucleic acids as compared to the dot blot technique (27\%). Our explanation, confirmed with RNAse digestion (5). was that not only DNA.DNA hybrids formed but that also mRNA-DNA hybrids contributed significantly to the hybridization reactivity observed. These mRNAs transcribed from IE genomic regions seem to be present not only during reproductive viral cycles (6) but also during latent infections. However, using in situ DNA hybridization with the $\mathrm{BH}$ probe only a small percentage $(14 \%)$ of samples could be demonstrated to contain CMV nucleic acids, suggesting that no MRNA-DNA hybrids formed. The presence of IE MRNAs has been demonstrated using in situ DNA hybridization techniques with DNA probes derived from IE genomic regions for Herpes Simplex virus latently present in human trigeminal ganglia $(16,17,18)$, while no HSV nucleic acids could be detected when these ganglia were probed with DNA derived from genomic regions coding for structural proteins (15). Our results with both DNA hybridization techniques therefore show a parallel situation for CMV, indicating that the human arterial wall is a site of latency for this virus. Histologically, the CMV nucleic acid sequences detected with both probes were mostly located in smooth muscle celis in the media of apparently normal arterial tissue. 
Using the PCR we showed that all samples reactive with primers derved from IE genomic regions were aiso reactive with primers derved from late genomic regions thus prowng that provably the whote wiral genome is consened in the human arterial wat.

The percentage of samples obtaned from patents with maximaly grade 1 atherosclerosis containing CMV nucleic acids as shown by in sivu DNA hybridization with the ES probe (58\%) equals the percentage found by PCR (53\%). Both techniques seem to have equal senstwy when studying apparenty nomal arterial wals using these probes and primers. However, when studying severely atherosclerotic antarial walls, PCR is superion. This can be explained by the locallzation of the CMV nucleic acids in the apparenty nomal smooth muscle cels in the arterat media. This arterial media has undergone massive atheromatous changes with greatly increased numbers of mononuclear leukocytes with macrophages and T-fymphocytes (19) in patients suffering from severe atherosclerosis with only few smooth muscle cells let, reducing the chance of foding CMV nucleic acids by in situ DNA hybridzation. The finding that $90 \%$ of the samples obtained from patient suffering from severe atheroscierosis contained CMV nucleic acids using PCR, as compared to $53 \%$ of the samples obtained from patients with maximally grade atherosclerosis does suggest a role for this virus in the pathogenesis of this disease. The reactivation of this latent virus to a local byic infection in the vessel wall might result in repeated local inflammatory reactions that, in concert with other established risk factors, may lead to atheroma formation.

\section{References}

1. Melnick JL, Petrie BL, Dreesman GR, Burek J, McCollum CH, Debakey ME. Cytomegallovirus antigen within human arterial smooth muscle cells. Lancet 1983 , 2: $644-647$.

2. Petrie BL, Melnick JL. Adam E, Burek J, McCollum CH, Debakey ME. Nucleic acid sequence of cytomegalovirus in cells cultured from human arterial tissue. J Infect Dis 1987, 155: 158-159.

3. Benditt EA, Barret T, McDougall JK. Viruses in the etiology of atherosclerosis. Proc Natl Acad Sci USA 1983: 6386-6389.

4. Yamashiroga HM, Ghosh L, Yang $R$, Robertson L. Herpes viridae in the coronary arteries and aorta of young trauma victims. Am J Path 1988, 130: 71-79.

5. Hendrix MGR. Domans PHJ. Kitslaar P. Bosman F. Bruggeman CA. The presence of CMV nucleic acids in arterial walls of atherosclerotic and non-

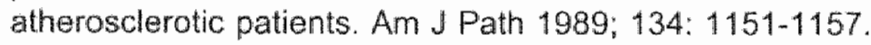

6. Stinski MF. Thomsen DR, Stenberg RM, Goldstein LC. Organization and expression of the immediate early genes of the human cytomegalovirus. J Virol 1983 , 46: $1-14$.

7. Maniatis T, Fritsch EE, Sambrook \. Molecular cloning - a laboratory manual. Cold Spring Harbor Lab. Cold Spring Harbor, New York, 1982.

8. Somogyl T. Colimon $R$, Michelson S. An illustrated guide to the structure of the human cytomegalovirus genome and a review of transcription data. Prog Med Virol 1986, 33: 99-133.

9. Pande H, Baak SW, Riggs AD, Clark BR, Shively JE, Zaia JA. Cloning and physical mapping of a gene fragment coding for a 64-Kilodalton major late antigen of human cytomegalovirus. Proc Natl Acad Sci USA 1984, 81: 4965 4969.

10. Rüger B, Klages S, Walla B, Albrecht J, Fleckenstein B, Tomlinson P, Barrel B. Primary structure and transcription of the genes coding for two phosphoproteins pp65 and pp71 of human cytomegalovirus. J Virol 1987, 61: 446-453.

11. Birnboim HC, Doly J. A rapid alkaline extraction method for the isolation of 
plasmid DNA. Nucl Acid Res 1979, 7: 1513-1518.

12. Meyer H, Dreesen JCFM, van Boven CPA. Molecular cloning and restriction endonuclease mapping of rat cytomegalovirus genome. J Gen Virol 1986,67 : $1327-1342$.

13. Akrigg $A$, Wikinson $G W G$, Oram JO. The structure of the major immediate early gene of human cytomegalowirus strain AD169. Virus Research 1985, 2: 107-121.

14. Shibata D, Martin WJ, Appleman MD, Causey DM, Leedom JM, Amheim NA. Detection of cytomegalovirus DNA in peripheral blood of patients infected with human immunodeficiency virus. J Infect Dis 1988, 158: 1185-1192.

15. Saiki RK, Scharf S, Faloona F, Mullis KB, Horn GT, Erlich A, Amteim N. Enzymatic amplicifation of $B-g l o b i n$ genomic sequences and restriction site analysis for diagnosis of sickle cell anemia. Science 1985, 230:1350-1354.

16. Stevens JG, Haar L, Porter DD, Cook ML, Wagner EK. Prominence of the Herpes Simplex virus latency associated transcript in trigeminal ganglia from seropositive humans. J Infect Dis 1988, 158: 117-123.

17. Croen KD, Ostrove JM, Dragovic LJ, Smialek JE, Straus SE. Latent Herpes Simplex virus in human trigeminal ganglia. N Engl J Med 1987, 23: 1427-1432.

18. Wagner EK, Devi-Rao G, Feldman LT, Dobson AT, Zhang Y, Flanagan MM, Stevens JG. Physical characterization of the Herpes Simplex virus. Latencyassociated transcript in neurons. J Virol 1988, 62: 1194-1202.

19. Hansson GK, Jonasson L. Holm J, Claesson-Wish L. Class II MHC antigen expression in the atherosclerotic plaque: smooth muscle cells express HLA-DR, HLA-DQ and the invariant gamma chain. Clin Exp Immunol 1986, 64: 261-268. 


\section{CHAPTER 5}

\section{Cytomegalovirus nucleic acid distribution within the human vascular tree}

M.G.R. Hendrix

M. Daemen

C.A. Bruggeman

American Journal of Pathology 1991; 138:563-567. 


\section{Abstract}

The presence of human cylomegatovirus (HCMV) nucleic acids was demonstrated in almost all major arteries of HCMV-seropositive patients by polymerase chain reaction. The amount of HCMV mucleic acids present in the arterial wall was calculated to be less than 2 viral genornic equivalents per 2500 human genomic equivalents. No relation was observed between the presence of HCMV nucleic acids in the arterial wall and the existence of atherosclerotic changes. No differences were abserved in the number of viral genomic equivalents present at sites with or without atherosclerosis. Apart from a role for HCMV in the pathogenesis of atherosclerosis the presence of atent HCMV in the arterial tree provides a powerful system to describe the physical state of this latently present virus.

\section{Introduction}

Infections with human cylomegalovirus (HCMV) are common, and a prominent characteristic feature of this virus is that it persists in the host after a primary infection. Frequent reactivation from this latent state has been documented by various authors (1).

Recently, several reports suggested that the arterial wall might be a site of latency for this virus $(2,5)$ and it was suggested that frequent reactivation from this latent state might contribute significantly to the pathogenesis of atherosclerosis $(2,3,4,5,6,7)$.

In our laboratory we could demonstrate by dot blat and in situ DNA hybridization, and by polymerase chain reaction (PCR) $(4,5)$, that the complete viral genome was present in a latent form in a high percentage of arterial wall specimen obtained from proximal elastic arteries. We were also able to show by PCR that the prevalence of CMV nucleic acids was much higher in samples obtained from patients with grade III atherosclerosis $(90 \%)$ as compared to samples obtained from matched controls with maximally grade atherosclerosis $(50 \%)$. These findings do indeed suggest a role for this virus in the pathogenesis of atherosclerosis. Most arterial samples, however, were taken from arteries prone to develop atherosclerosis. Various autopsy series clearly demonstrated that atherosclerosis is not a general disease of all the arteries but that there are several predelection sites in the human arterial tree at risk to develop lesions. These studies demonstrated a high prevalence of atherosclerotic lesions in abdominal aorta, carotid artery, common lliac artery and left anterior descending antery but showed a low prevalence in celiac and pulmonal arteries. Considering a role for CMV in the pathogenesis of atherosclerosis, one may suggest a tropism from this virus for these predelection sites or that simply more viral nucleic acids will accumulate at these arterial sites as. compared to the non-atherosclerotic sites.

In this report we describe the distribution of CMV nucleic acids over the human arteria! tree in a qualitative way as determined by polymerase chain reaction, and in a semiquantitative way as determined by dot blot DNA hybridization.

\section{Materials and methods}

\section{Tissue specimen}

The subjects of this study consisted of HCMV-seropositive patients on whom autopsy was performed within 12 hours after death. Seropositivity for HCMV was confirmed by using a latex agglutination test (CMV scan Beckton \& Dickinson, Oxford, UK).

Only patients with non-CMV related disease were included in this study. Patients suffering from immunosuppressive disease or undergoing immunosuppressive therapy were strictly excluded. The possibility of active CMV infection or reactivation of latently 
present virus was ruled out by testing for the presence of IgM and IgA anti-CMV antibodies using a capture technique (8). At autopsy samples were taken from all major elastic arteries (Table 1 and 2) and from the portal vein.

\section{Processing of tissue specilnen}

Tissue specimen for in situ DNA hybridization were formalin fixed and paraffin embedded using routine histologic procedures. For PCR and semi-quantitatwe dot blot DNA was extracted from the tissue specimen by proteolytic digestion and phenol-chloroform extraction followed by ethanol precipitation (4).

\section{Microscopy}

All sections were routinely stained with haematoxylin-eosin (H\&E) and investigated for the presence of atherosclerosis. Only vessel walls with minimal intimal thickening and no signs of atheroma formation were considered to be free of atheroscierosis.

\section{Oligomer synthesis}

The oligomers used as primers in the PCR were synthesized on a DNA synthesizer (cyclone DNA synthesizer, Biosearch Inc., New Brunswick. NJ) by the fosfamidid method. The sequences for the oligomer set reactive with the major Immediate early gene were based on the sequence described by Akrigg et al. (9) and were located in the ES fragment used as a probe for the DNA hybridization techniques. The sequences are: $5^{1}-$ GGA-GAT-GTG-GAT-GGC-TTG-TA-3" (IE, upstream primer) and $5^{1}-$ GAA-GGCTGA-GTT-CTT-GGT-AA-3 ${ }^{1}$ (IE -2 downstream primer). The oligomer set reactive with the human B-globine gene has been described elsewhere (10). The sizes of the PCR amplification products of the IE and the $B$-globin targets are 170 and 110 base pairs respectively. The specificity and sensitivity of both primer sets have been tested extensively $(5,10)$.

\section{Polymerase chain reaction}

The polymerase chain reaction protocol performed on extracted cellular DNA has been described previously (5) and was performed on a prem 111 cycler (LEP Scientific, Buck. UK). After a total of 35 cycles of amplification $10 \mu l$ of the reaction mixture was subjected to electrophoresis on $2 \%$ agarose gels (Seakem GTG FMC Bioproducts, Rockland, ME) containing $0.5 \mu \mathrm{g} / \mathrm{ml}$ Ethidium Bromide. The amplification product was visualized by ultraviolet fluorescence. DNA samples that did not show reactivity with the CMV primers were further analysed with the primer set reactive whth the B-globin gene to check on DNA preservation.

\section{Hybridization probes}

DNA hybridization was performed with the $7.0 \mathrm{~Kb}$ ES fragment $(4,5)$, an EcoR,-Sall

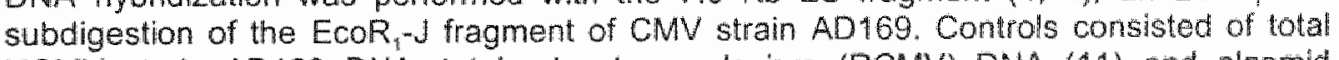
HCMV strain AD169 DNA, total rat cytomegalovirus (RCMV) DNA (11) and plasmid pBR328 DNA without inserts. In all DNA biotin was inserted by incorporation of biotin11 -dUTP (Bethesda Research Laboratories) using a random primed DNA labeling kit (Boehringer, Mannheim, FRG).

\section{Semiquantitative dot blot DNA hybridization}

Spotting of cellular DNA on nitrocellulose paper, hybridization conditions, and visualisation of successful hybridization was carried out as described previously $(4,5)$. The specificity of the biotinylated probes has been evaluated extensively $(4,5)$. Each arterial DNA sample was serially diluted to produce spots of $1,0.5,0.25,0.12 \mu \mathrm{g}$ DNA respectively. Controls consisted of purified HCMV DNA and DNA extracted from non-infected human embryonic fibroblasts (HEF. Flow 2002, Flow Laboratories, McClean, VA). To 
estimate the amount of viral DNA present in the arterial DNA samples spots were produced of $1,0.5,0.25,0.12,0.06,0.03$ picogram purified HCMV DNA made up to a total of $0.5 \mu g$ DNA per spot with DNA extracted from non-infected HEF. In all experiments $0.1 \mathrm{pg}$ of purified HCMV DNA could be detected equaling approximately 350 viral genomic equivalents (VGE) (MW=1.7.10 Dalton). Estimating the total DNA content of one cell nucleus to be 6.6.10"11 Dalton, it is possible to calculate the amount of VGE present per thuman genomic equivalent (HGE).

\section{In situ DNA hybridization}

The in situ DNA hybridization protocol performed on $4 \mu \mathrm{m}$ thick tissue sections has been described previously (5). The specificity of the biotinylated probes as been evaluated extensiveny (5).

\section{Statistical analysis}

Statistical analysils was carried out using Fisher's exact tests. Results were considered significant when $\mathrm{p}<0.01$.

\section{Results}

\section{Tissue specimen}

Nine autopsy patients ( 5 men, 4 women) with a mean age of 74 years (range 47 to 92 years) were avallable. Three men and 4 women died of metastatic neoplastic disease (colon carcinoma: 3; breast carcinoma: 3; thyroid carcinoma: 1) and 2 men died of cardiac arrest. All subjects available for this study were shown to contain anti-HCMV antibodies of the $\operatorname{lgG}$ class, but not of the $\operatorname{lgM}$ or $\lg A$ class, which excluded primary and frequently reactivating disease. These nine autopsy patients provided 77 arterial samples.

\section{Microscopy}

From all arterial samples 58 of $77(75 \%)$ showed clear signs of atheroscllerosis with marked intimal thickening and sometimes atheroma formation. Only the pulmonal artery was almost always free of atherosclerotic changes (Table 1). Only in 1 of $7(14 \%)$, slight intimal thickening was observed. Each individuall patient showed atherosclerotic disease of 6 or more main vessels but also had arteries free of intimal thickening, making this group of patients suitable for this study.

\section{Polymerase chain reaction}

The polymerase chain reaction (PCR) performed on extracted DNA from all major arteries (Table 1) showed that 72 of 77 (94\%) samples contained HCMV nucleic acids. These nucleic acids were equally distributed over the vascular tree.

There was no difference observed in the prevalence of HCMV DNA in samples obtained from arteries with atherosclerotic changes as compared with samples obtained from microscopically normal arterial walls $(p=0.36)$.

Samples negative for HCMV nucleic acids by PCR (5 of $77(6 \%)$ ) were checked for DNA integrety with a primer set reactive with the human B-globin gene. All samples tested with this primer sel were positive for the presence of the B-globin gene proving that the DNA integrety was sufficient for PCR analysis. 


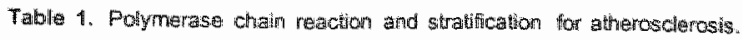

\begin{tabular}{|c|c|c|c|c|}
\hline Vessell & $\begin{array}{c}\text { PCR(lowaly } \\
\text { pos/total } \\
(\%) !\end{array}$ & $\begin{array}{c}\text { authiorosicternsig } \\
\text { positotal } \\
(\%)\end{array}$ & $\begin{array}{c}\text { PCR * and } \\
\text { atheroscierosis * }\end{array}$ & $\begin{array}{c}\text { PCR + and } \\
\text { atherosererosis. }\end{array}$ \\
\hline $\begin{array}{l}\text { Thoracic aorta } \\
\text { Abdominall ach } \\
\text { Carodid antery } \\
\text { Superior mesentaric artery } \\
\text { Celiac artery } \\
\text { Renal artery } \\
\text { Common iliac antery } \\
\text { Puironary antery } \\
\text { Left anterior descending } \\
\text { antein } \\
\text { Portal vein }\end{array}$ & $\begin{array}{l}8 / 9 \\
8 / 9 \\
8 / 9 \\
819 \\
7 / 7 \\
9 / 9 \\
9 / 9 \\
77 \\
8 \% \\
819 \\
\end{array}$ & 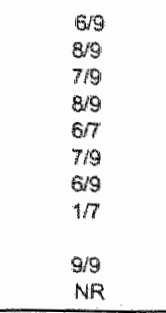 & $\begin{array}{l}5 / 6 \\
816 \\
7 / 7 \\
718 \\
616 \\
7 / 7 \\
616 \\
1 / 1 \\
09 \\
\mathrm{NR}\end{array}$ & $\begin{array}{l}3 / 3 \\
0,1 \\
1 / 2 \\
1 / 1 \\
1 / 1 \\
22 \\
313 \\
616 \\
00 \\
\text { NR }\end{array}$ \\
\hline $\begin{array}{l}\text { Total arteries } \\
\text { (except portal wein) }\end{array}$ & $\begin{array}{l}72 / 77 \\
(94 \%)\end{array}$ & $\begin{array}{l}5877 \\
(75 \%)\end{array}$ & $\begin{array}{l}55 / 50 \\
(95 \%)\end{array}$ & $\begin{array}{l}7719 \% \\
190 \%\end{array}$ \\
\hline
\end{tabular}

NR, not relevant

\section{Semiquantitative dot blot DNA hybridization}

Using the dot blot DNA hybridization technique (Table 2), HCMV nucleic acid sequences were detected in 58 of $77(75 \%)$ samples. HCMV DNA was detected in 43 of $58(73 \%)$ samples obtained from atherosclerotic arteries and in 15 of $18(83 \%)$ samples obtained from normal arteries. Statistical analysis showed this difference not to be significant $(p=0.46)$. Most of the samples containing detectable amounts of HCMV nucleic acids only showed positive hybridization in the less diluted DNA samples meaning that $0.1-0.2$ pg of viral DNA was present in $1 \mu \mathrm{g}$ DNA extracted from arterial walls. From this we concluded that approximately 1 to 2 viral genomic equivalents (VGE) were present per 2500 human genomic equivalents (HGE). Only 4 samples, all obtained from one patient, could be diluted fourfold and still show positive hybridization. This means that in these samples approximately 1 to 2 VGE were present per 600 HGE. There was no difference observed in the number of VGE per HGE present in arteries with or without atherosclerotic changes.

All samples negative with the dot blot DNA hybridization technique but positive by PCR should contain less than 1 VGE per $2500 \mathrm{HGE}$. In situ DNA hybridization of sections of arteries with atherosclerotic changes showed that 24 of $58(41 \%)$ contained HCMV nucleic acid sequences whereas sections of arteries without these changes showed the presence of nucleic acids in 7 of $19(37 \%)$, which was not statistically different.

\section{In situ DNA hybridization}

Histologically the HCMV nucleic acid sequences detected with the in situ DNA hybridization technique were mostly located in apparently normal arterial tissues without atherosclerotic changes. Only in a few occasions the viral nucleic acids were located in the thickened intimal layer. No HCMV nucleic acid sequences were detected in sites of atheroma formation. Sequential sections stained with H\&E showed that the DNA hybridization reactivity mostly was located in smooth muscle cells in the arterial media. 


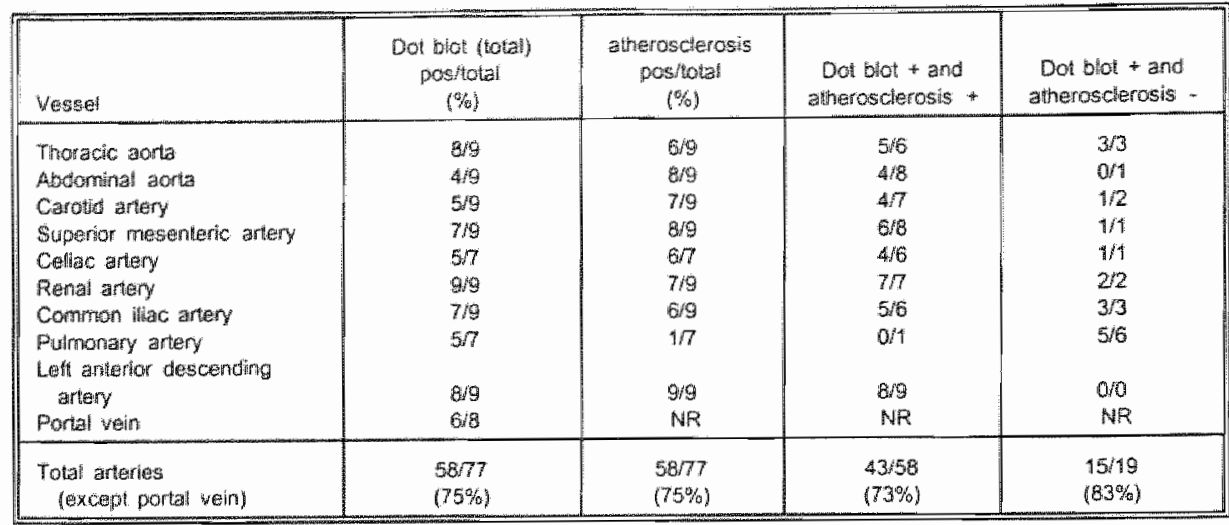

NHR, not relewant

\section{Discussion}

In this study we have demonstrated by PCR that probably all major arteries obtained from HCMV seropositive patients contain HCMV nucleic acid sequences. These nucleic acids are equally distributed among arteries with and without atherosclerotic changes. By using semiquantitative dot blot DNA hybridization techniques it was possible to estimate that approximately 2 or less viral genomic equivalents (VGE) are present per 2500 human genomic equivalents (HGE).

There were no differences observed in the number of VGE per HGE present in arteries with or without atherosclerotic changes. HCMV nucleic acids were mostly lacated in smooth muscle cells of the arterial media as shown by in situ DNA hybridization.

One of the objects of this study was to look if HCMV nucleic acids preferentially accumulated at arterial sites prone to develop atherosclerotic lesions. The finding that almost all arteries contain HCMV nucleic acids and that there is no correlation with atherosclerotic sites clearly shows that there is no tropism from the HCMV for these predelection sites. These results could more or less be predicted from previous reports demonstrating the presence of HCMV in various arteries from patients with severe atherosclerosis but also in abdominal aortas without atherosclerotic changes $(2,3,4,6)$. Also from our previous findings using PCR (5) and demonstrating a high prevalence of HCMV nucleic acids in patients with grade III atherosclerosis (90\%) but also in patients with maximally grade $\|$ atherosclerosis $(50 \%)$ did suggest these results. As already stated $(4,5)$ we don't suggest a direct rale for HCMV in the pathogenesis of atherosclerosis.

The finding that arteries with or without atherosclerotic changes contain approximately equal numbers of vira! genomic equivalents (VGE) per human genomic equivalent (HGE) also means that there is no direct relationship between the HCMV and the presence of atherosclerosis and again a possible reason for these findings is that the vessels under investigation represent end stage atherosclerotic changes not influenced anymore by the HCMV. The role for HCMV in the pathogenesis of atherosclerosis might be at the start of this disease with the development of fatty streaks $(12,13)$. Considering the tropism from HCMV for endothelial cells (15) infection of these cells could result in the production of inflammatory mediators such as interleukin 1 . which subsequently induce activation and adherence of leucocytes responsible for injury of the endathelium (13) being the inital process in the response to injury theory of Ross (14). This injury, in 
co-operation with other established risk factors, could start the process of atherogenesis. Once present in the arterial wall the HCMV will remain latently present for the rest of life. Transient local reactivation from this latent state (16) might also contribute further to the process of atherogenesis.

Apart from the process of atherogenesis the presence of latent HCMV in the human arterial wall remains an intriguing phenomenon. Considering the wide tropism of this virus for many different tissues during reproductive infection (17) one might ask if the human vascular wall is the only site of latency. Probably more cellypes will contain latent HCMV. Our finding that at most 2 VGE are present per 2500 HGE may substantiate this probabillty because these low numbers were until recentily beyond the reach of molecular biology.

Comparable viruses like Herpes Simplex virus (HSV) were found to be present at at least 1 VGE per $100 \mathrm{HGE}$ in trigeminal ganglia (18) facilitating their detection. Objects for further research are therefore obvious. At first screening ather wissues on the presence of latent HCMV and secondly characterization of the physical state of this virus at least latently present in the human arterial tree.

\section{References}

1. Ho, M. Cytomegalovirus biology and infection. Plenum Medical Book Co. 1982, New York.

2. Melnick, J.L., Petrie, B.L., Dreesman, G.R., Burek, J., McCollum, C.H., Debakey, M.E. Cytomegalovirus antigen within human arterial smooth muscle cells. Lancet 1983; 2: 644-647.

3. Yamashiroga, H.M., Ghosh. L. Yang, R., Robertson, L. Herpes viridae in the coronary arteries and aorta of young trauma victims. Am. J. Path. 1988; 130: 71. 79.

4. Hendrix, M.G.R., Dormans, P.H.J., Kitslaar, P., Bosman, F., Bruggeman, C.A. The presence of CMV nucleic acids in arterial walls of atherosclerotic and nonatherosclerotic patients. Am. J. Path. 1989; 134: 1151-1157.

5. Hendrix, M.G.R., Salimans, M.M.M., van Boven, C.P.A. Bruggeman, C.A. High prevalence of latently present cytomegalovirus in arterial walls of patients suffering from grade $\| l$ I atherosclerosis. Am. J. Path. 1990; 136:23-28.

6. Melnick, J.L., Adam, E., Debakey. M.E. Possible role of cytomegalovirus in atherogenesis. J.A.M.A. 1990; 263: 2204-2207.

7. Grattan, M.T., Moreno-Cabral, C.E. Stames, V.A. Oyer, P.E. Stinson, E.B., Shumway, N.E. Cytomegalowirus infection is associated with cardiac allograft rejection and atherosclerosis. J.A.M.A. 1989; 261: 3361-3366.

8. van Loon, A.M., Heessen, F.W.A. van der Logt. J.Th.M., van der Veen, J. Direct enzyme-linked-immunosorbent-assay that uses peroxidase-labeled antigen for determination of immunoglobulin $M$ antibody to cytomegalovirus. J. Clin. Micr. $1981 ; 13: 416-422$.

9. Akrigg, A., Wilkinson, G.W.G., Oram, J.D. The structure of the major immediate early gene of human cytomegalovirus strain AD169. Virus Research 1985; 2: $107-121$.

10. Salki, R.K., Schauf, S., Faloona, F., Mullis, K.B. Horn, G.T., Erich. A., Armheim, N. Enzymatic amplification of B-globin gemomic sequences and restriction site analysis for diagnosis of sickle cell anemia. Science 1985; $230 ; 1350-1354$.

11. Meijer, H., Dreesen, J.C.F.M. van Boven, C.P.A. Molecular cloning and restriction endonuclease mapping of the rat cytomegalovirus genome. J. Gen. Virol. $1986 ; 67: 1327-1342$.

12. Munro, M.J., Cotran, R.S. The pathogenesis of atherosclerosis: atherogenesis 
and inflammation. Lab. Invest. 1988; 58: 249-261.

13. Bruggeman, C.A., van Dam-Mieras, M.C.E. The possible role of Cytomegalovirus in atherogenesis. Progress in Medical Virology 1990, Karger AG, Basel, Switzerland. (in press).

14. Ross, R. The pathogenesis of atherosclerosis: an update. New Engl. J. Med. 1986; $314: 488-500$

15. Toorkey, C.B., Carriglan, D.R. Immunohistochemical detection of an immediate early antigen of human cytomegalowirus in normal tissues. J. Infect. Dis. 1989; $160: 741-751$.

16. McVoy, Adler. Immunologic evidence for frequent age-related CMV reactivation in seropositive immunocompetent individuals. J. Infect. Dis. 1989; 160: 1-10.

17. Myerson, D., Hackman, R.C., Nelson, J.A., Ward, D.C., McDougall, J.K. Widespread presence of histologically occult cytomegalovirus. Human Path. 1984; 15: $430-439$.

18. Efstathion, S., Minson, A.C., Field, H.J., Anderson, J.R., Wildy, P. Detection of Herpes Simplex virus-specific DNA sequences in latently infected mice and in humans. J. Virol. 1986; $57: 446-455$. 


\section{CHAPTER 6}

\section{Widespread presence of cytomegalovirus DNA in tissues of healthy trauma victims}

Ron M.G. Hendrix

Mariette Wagenaar

Rob L. Slabbe

Catrien A. Bruggeman

Journal of Clinical Pathology 1997; 50:59-63 


\section{Abstract}

Aims: To determine the locallsation of human cytomegalovirus (HCMV) DNA in abdominal aorta, spleen, and transplantable organs such as kidney, pancreas, and liver obtained from healthy individuals; to characterise the cell type(s) in these tissues that serve as a reservoir for latent HCMV.

Methods: HCMV DNA was detected by dot blot DNA hybridization and in situ DNA hybridization with a probe for CMV major immediate early sequences (UL123) and nested PCR with primers derived from the CMV major immediate early (IE) gene exon 4 (UL123ex4). Samples of liver, abdominal aorta, spleen, kidney and pancreas were obtained at necropsy or at donor nephrectomy from healthy patients.

Results: CMV DNA was detected in most tissue samples using dot blot hybridization and nested PCR. In situ hybridization demonstratethat, in addition to smooth muscle cells in the arterial wall, hepatocytes, tubular and glomerular kidney cells, splenic red pulp cells, and pancreatic acinar cells also harboured CMV DNA. CMV DNA was detected in seropositive and in some seronegative subjects.

Conclusion: CMV DNA is widely distribution in organs of healthy subjects. CMV DNA was found in various cell types in several organs, suggesting that during latency, CMV DNA is present thoughout the body.

\section{Introduction}

Infection by human cytomegalovirus (CMV), a herpesvirus, can result in a variety of disorders ranging from subclinical disease in normal subjects to often fatal disease in immunocompromised patients (1). CMV can establish latent infections. Virus reactivation followed by active infection has been clearly demonstrated in recipients of organ transplants and often leads to life threatening disease (1). Seronegative recipients of donor organs are at particular risk of developing CMV disease (1). Molecular epidemiological studies have shown that two recipients receiving organs from the same donor excrete identical CMV strains in the urine,(2), demonstrating that HCMV transmission occurs with the graft. However, the cell types or types of graft that serve as a reservoir for latent CMV are unknown. Several reports have suggested that latent CMV is present in the smooth muscle cells of the arterial wall $(3,4,5,6)$. Using PCR, we detected CMV DNA in the arterial wall in almost $70 \%$ of CMV seropositive patients (5) and using in situ DNA hybridization showed that arterial smooth muscle cells harboured the virus. In other reports CMV nucleic acids were found in peripheral leucocytes obtained from healthy CMV seropositive and seronegative subjects $(7,8)$.

In this report we describe the presence and location of HCMV DNA in aorta, kidney, spleen and pancreas of healthy organ donors.

\section{Materials and methods}

\section{Tissue specimen}

Two groups of patients were included in this study.

Group 1 comprised trauma victims (eight men, five women) available for donor nephrectomy. Samples were taken from the abdominal aorta, spleen and pancreas using strict aseptic surgical techniques. Twelve artery, 12 spleen, and 8 pancreatic samples were collected from these subjects. The mean age of the subjects was 35 years (range 8 to 45 years). CMV DNA was detected using in situ DNA hybridization and PCR. If there was sufficient tissue, dot blot DNA hybridization was also done. 
Group 2 comprised patients (six men, two women) with no relevant medical history who died of sudden cardiac arrest. Samples were taken at necropsy from the spleen, liver, and kidney. All samples were taken within 12 hours of death using aseptic techniques. Eight spleen, 8 liver, and 8 kidney samples were collected. The mean age of the subjects was 65 years (range 54 to 75 years). In most cases CMV was detected by PCR only. Some liver and kidney samples were examined using in situ DNA hybridization to identify the cell types harbouring CMV DNA.

All tissue samples were handled separately to avoid cross contamination. Tissues from which DNA was to be isolation were stored at $4^{\circ} \mathrm{C}$ in $50 \%$ ethanol. Tissues for in situ DNA hybridization were fixed routinely in formalin and embedded in paraffin wax.

\section{Serology}

Seropositivity for human Cytomegalovirus was determined for all patients using a latex agglutination test (CMV-scan, Becton Dickinson, Cockeysville, MD, USA) (9), an IgG ELISA from Organon Teknika, Boxtel, The Netherlands, and an in-house ELISA based on AD169 infected cell lysate. To establishactive infection, IgM anti-HCMV antibodies were detected using a capture ELISA technique (10). All serum samples were taken directly on arrival of the subjects at our hospital.

\section{DNA extraction from tissues and tissue sections}

DNA for dot-blot DNA hybridization and PCR analysis was extracted from the ethanol preserved tissues. Small tissue samples were collected in $1.5 \mathrm{ml}$ polypropylene microcentrifuge tubes. Subsequent proteolytic digestion of all samples was carried out overnight at $50^{\circ} \mathrm{C}$ in a mixture of $10 \mathrm{mM}$ Tris- $\mathrm{HCl}(\mathrm{pH}=7,5), 5 \mathrm{mM}$ EDTA, $100 \mathrm{mM} \mathrm{NaCl}$, 250 microgram/ml proteinase K (Boehringer Mannheim, Federal Republic of Germany) and $10 \mathrm{mg} / \mathrm{ml}$ SDS under constant agitation. The DNA was purified by phenol-chloroform extraction and ethanol precipitation and finally dissolved in 50 microliter distilled water. To exclude the possibility of cross contamination during these procedures, herring sperm DNA was included as a negative control. DNA were included.

\section{Oligonucleotides}

Oligonucleotides purchased from Eurogentec (Liege, Belgium) were derived from the CMV major immediate early gene exon 4 (UL123ex4). The nucleotide sequences of primers used for nested PCR are: first round: A1 5'-ACGAA-TTCGT-AATGA-AGCGCCGCAT-TGA-3' and A2 5'-ACGAG-CTGCA-ATAGT-GACGT-GGGAT-CCA-3'; second round: B1 5'-ACGAT-TTCTC-TGCAT-GAAGG-TCTTT-GC-3' and B2 5'-ACGAG-CTCGTGGGAT-CCATA-ACAGT-AA-3'; internal probe: C 5'-CAGTA-ATTGT-GGCGT-AGAACAGTGA-TCAGG-3'. The nested PCR product was 468 basepairs. The primer set reactive with the B-globin gene has been described previously (11).

\section{Hybridization probes}

A $7.0 \mathrm{~kb}$ EcoR1-Sal1 fragment from the EcoR1-J fragment of the CMV AD169 strain (5) which contains the major immediate early gene, was used as a probe. The probe was labelled with biotin by incorporating biotin-11-dUTP (Bethesda Research Laboratories, U.S.A.), using a random primed DNA labelling kit (Boehringer Mannheim, Germany).

\section{Dot blot DNA hybridization}

Transfer of cellular DNA to nitrocellulose paper, hybridization conditions, and visualisation of successfull hybridization were carried out as described previously (5). The specificity of the biotinylated probe has been evaluated extensively (5).

\section{Nested polymerase chain reaction}

The reaction mixture contained standard PCR buffer (10x PCR buffer, Promega, USA) 
supplemented with $\mathrm{MgCl}_{2}$ to a final concentration of $2,4 \mathrm{mM}$ and $250 \mu \mathrm{M}$ of each dNTP in a reaction volume of $50 \mu$. Ome nanogram of each primer and 1 unit DNA polymerase (Ampli-taq, Perkin-Eimer-Cetus, USA) and 200 ng target DNA were added. After 30 cycles of 1 minute at $94 \mathrm{C}, 1$ minute at $58 \mathrm{C}$ and 2 minutes at $72^{\circ} \mathrm{C}$ on a Prem III thermal cycler (LEP Scientific, Great Britain), $1 \mu$ l of the reaction mixture was transferred to the second reaction tube containing the nested primer for the second round $P C R_{\text {, }}$ carried out onder the same conditions. After 40 cycles, $10 \mu l$ of the second reaction mixture was subjected to electrophoresis on $2 \%$ agarose gels (Seakem GTG FMC Bioproducts, USA) and transferred to a nylon filter (Hybond $N+$ Amersham, Great Britain). The internal oligonucleotide was end-labelled with $32 \mathrm{P}$ and used as a probe for hybridization of the nylon filters. All samples showing hybridization were considered to contain CMV DNA.

\section{In situ DNA hybridization}

The presence of CMV nucleic acids was detected using in situ DNA hybridization on sections $4 \mu \mathrm{m}$ thick as described previously (5).

\section{IInmunohistochemistry}

CMV specific antigens were detected immunohistochemically as described previously (12). A monoclonal antibody directed against the CMV 72 kilodalton IE antigen (UL123) (Dupont speciality diagnostics, Wilmington. USA) and the MC222 monocional antibody directed against the 65 kilodalton tegument protein of the virus particle, pp65 (ppUL83(PK)), were used (13)

\section{Results}

\section{Serology.}

Serum samples from four group I subjects did not contain CMV antibodies. All other subjects were CMV- positve. Results of all lgG tests showed $100 \%$ agreement. No CMV reactive antibodies of the IgM class were detected indicating that none of the subjects had active CMV disease.

\section{Immunohistochemistry}

Immunohistochemical studies were done using both monoclonal antibodies. Immunoreactivity was not

observed in any of the samples tested

\section{Dot blot DNA hybridization}

Twenty-three tissue samples from group 1 subjects were subjected to dot blot hybridization. Overall " 6 of 7 samples of aorta, 10 of 10 samples of spleen, and 3 of 6 samples of pancreas tharboured CMV DNA (table 1). Tissue samples from three of four seronegative donors ( 2 aorta, 3 spleen, and 1 pancreas) were evaluated by this technique. Of these, samples of aorta and spleen contained viral DNA, while that of the pancreas did not.

\section{Polymerase chain reaction}

In group 1 (table 1), 9 of 13 abdominal aorta, 12 of 12 spleen, and 6 of 8 pancreatic samples contained viral DNA. CMV DNA was also found in 3 of 4 seronegative subjects. In group 2, 8 of 8 spleen. 8 of 8 liver and 8 of 8 kidney samples harboured CMV DNA. The few samples which did not react with the CMV primers reacted well with the betaglobin primers. None of the numerous negative controls included nor any of the samples. containing DNA from the other known herpesviruses were positive. 


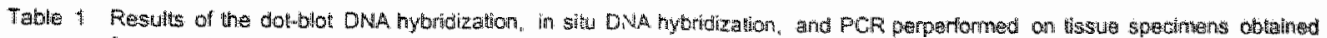
from previously healthy teartbeating donors. Each colvm represents a subject.

\begin{tabular}{|c|c|c|c|c|c|c|c|c|c|c|c|c|c|c|}
\hline & 01 & 02 & $p^{3}$ & 04 & 5 & $p 6$ & $p 7$ & 08 & pq & 010 & pit & $p 12$ & $p 13$ & total \\
\hline $\begin{array}{r}\text { dowblol (ES) arta } \\
\text { spleen } \\
\text { pancreas }\end{array}$ & $\begin{array}{c}+ \\
+ \\
N A B\end{array}$ & $\begin{array}{l}+ \\
+ \\
+\end{array}$ & $\begin{array}{l}\text { NA } \\
+ \\
+\end{array}$ & + & $\begin{array}{l}\text { NA } \\
+ \\
+\end{array}$ & $\begin{array}{l}\text { NA } \\
\text { NA } \\
\text { NA }\end{array}$ & $\ddot{*}$ & $\begin{array}{c}+ \\
+ \\
N A\end{array}$ & + & $\begin{array}{l}\text { NA } \\
\mathbb{N A} \\
\mathbb{N A}\end{array}$ & $\begin{array}{l}\text { MA } \\
\text { NA } \\
\text { NA }\end{array}$ & * & $\begin{array}{l}N A \\
+ \\
*\end{array}$ & $\begin{array}{c}677 \\
10140 \\
36\end{array}$ \\
\hline \begin{tabular}{|r} 
In-situ (ES) aorta \\
spleen \\
pancreats
\end{tabular} & $\begin{array}{l}+ \\
+ \\
\text { WA }\end{array}$ & + & $\begin{array}{l}* \\
+ \\
+\end{array}$ & $\begin{array}{l}+ \\
+ \\
+\end{array}$ & $\begin{array}{l}+ \\
+ \\
+\end{array}$ & NA & + & + & + & $\bar{x}$ & 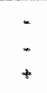 & $\begin{array}{l}* \\
* \\
\text { NA }\end{array}$ & $\begin{array}{c}\text { NA } \\
+ \\
+\end{array}$ & $\begin{array}{l}6112 \\
9 / 12 \\
67\end{array}$ \\
\hline $\begin{array}{r}\text { PCR MME-4y } \begin{array}{r}\text { aorta } \\
\text { spleen } \\
\text { pancreas }\end{array}\end{array}$ & $\stackrel{+}{+}$ & $\begin{array}{l}+ \\
+ \\
+\end{array}$ & $\begin{array}{l}* \\
* \\
*\end{array}$ & $\begin{array}{l}+ \\
+ \\
+\end{array}$ & $\begin{array}{l}+ \\
+ \\
+\end{array}$ & NA & + & $\begin{array}{c}+ \\
+ \\
N A\end{array}$ & $\begin{array}{l}+ \\
+ \\
+\end{array}$ & $\begin{array}{l}- \\
+\end{array}$ & + & $\begin{array}{l}* \\
* \\
M A\end{array}$ & $\begin{array}{l}\text { NA } \\
+ \\
+\end{array}$ & $\begin{array}{c}9 / 12 \\
12 / 12 \\
1318\end{array}$ \\
\hline serology & - & + & - & + & + & . & to & - & * & + & 4 & + & + & $4 / 13$ \\
\hline
\end{tabular}

Fig. 1 Photomicragraphs of in situ DNA hybridization of samples from four organs, Lsing HCMV-specific probes. The dark spots (arrow) represent hybridization. All sections are counterstained with methyl green. Panel A: Kidney $(400 x)$, Panel B: spleen $(400 x)$, Panel C: liver (400x), Panel D: pancreas $(400 x)$.
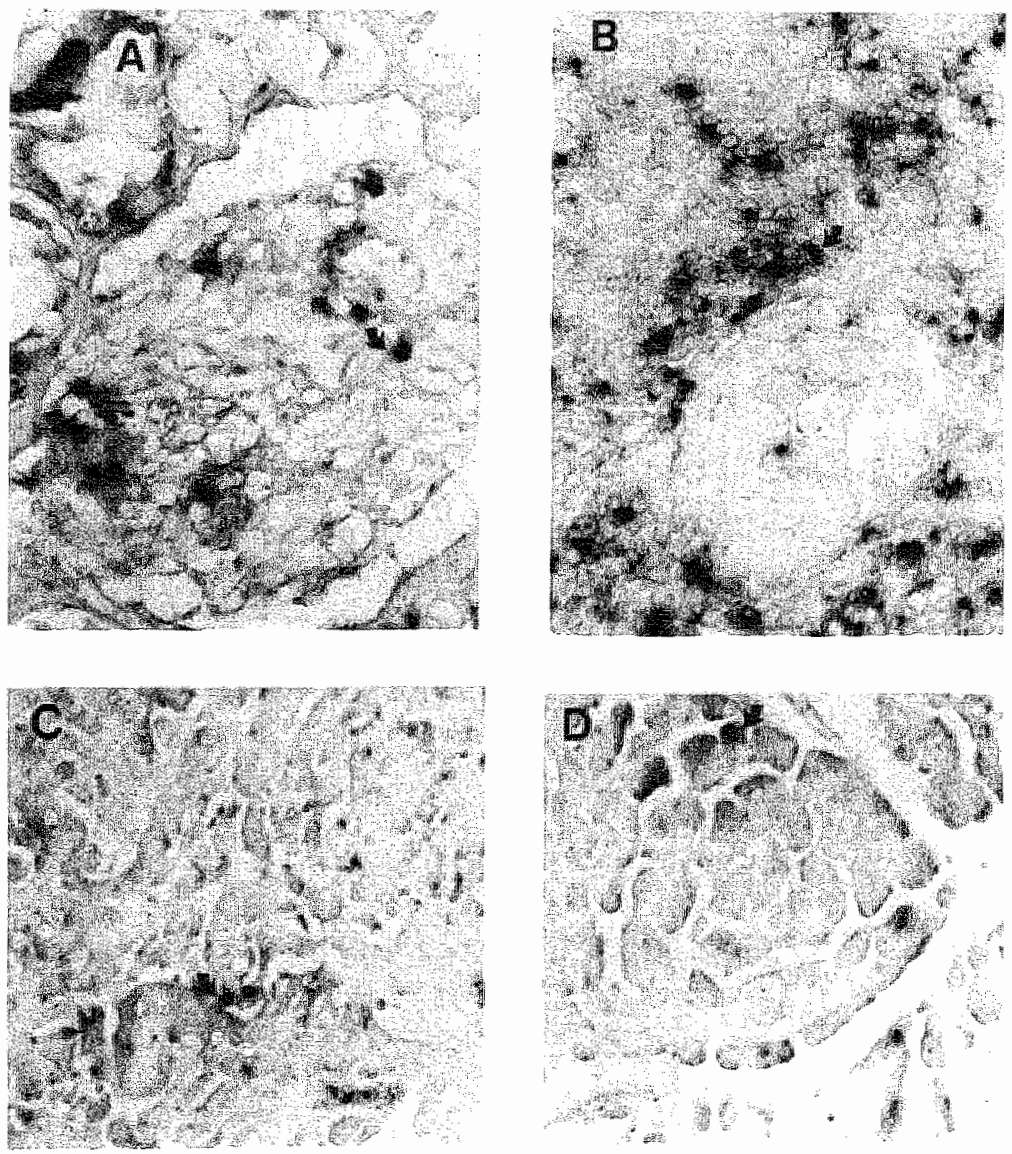


\section{In situ DNA hybridization}

The red pulp of the spleen often contained HCMV positive cells (fig. 1). In the kidney the epithelial cells of the tubulus were positive frequently. CMV DNA was also detected in epithelial cells of the glomerulus (fig. 1). Pancreatic acinar cells (fig. 1) hepatocytes were often positive.

\section{Discussion}

We have shown in the present study, that potential donor organs from both seropositwe and seronegative individuals can contain CMV DNA.

All Subjects were anti-CMV lgM negative, excluding active CMV infection. None of the subjects had had an immunosuppressive disease, again allowing us to conclude that they did not havee an active CMV infection. Therefore, the CMV DNA detected probably represents latent and not active virus.

As the hybridization studies do not discriminate between latency and low level infection we used immunohistochemistry to detect viral gene products. We did not observe immunoreactivity with a monoclonal antibody directed against immediate early gene products (UL123) nor with a monocional antibody directed against a late gene product, the viral tegument protein pp65 (ppUL83(pk)). These findings suggest tha latent CMV and not a low level productive infection was detected. Interestingly "Toorkey et al (14) detected CMV immediate early gene products, but not early nor late gene products, in normal tissue suggesting latent rather than low level productive infection. However, this immunoreactivity with immediate early gene products was observed anly with a single batch of the monoclonal antibody and could not be reproduced with another batch of that same antobody.

Our findings that CMV DNA can be detected in the aorta, spleen, pancreas, kidney, and liver suggest that the human arterial wall and peripheral leucocytes are not the only reservoirs for latent $C M V$ as described previously $(5,6,7,8)$, but that a variety of organs can harbour the viral genome.

$P C R$ is very sensitive to cross contamination between specimens (15) and to contamination by previously amplified DNA (15). However, the overall agreement of results obtained by dot blot hybridization "in situ hybridization "and PCR, and the absence of viral DNA in the numerous negative controls included in the PCR experiments in this study preclude the possibility of cross-contamination.

PCR studies of murine cytomegalovirus (MCMV) have shown that the lung, spleen, brain, heart, kidney, liver and salivary glands harbour latent MCMV DNA (16, 17, 18 , 19). The exact nature of the cell(s) carrying this MCMV DNA remain obscure. As shown in the present study by in situ DNA hybridization, many different cell types, such as hepatocytes, tubular and glomerular cells, and splenic red pulp cells, contained viral DNA. During active infection the virus is distributed widely and replicates in wirtually all cell types as shown by the appearence of specific viral cytopathological changes, the presence of viral antigens and the presence of viral DNA in various cells in almost all organs $(20,21)$.

Our finding that CMV DNA is present in a variety of organs obtained from previousty healthy seropositive subjects was not surprising, as several studies have clearly demonstrated transmission of CMV present in transplanted organs and peripheral blood obtained from CMV seropositive donors (22). The observation that in this study three of four seronegative patients carried CMV DNA is in accordance with other reports describing the presence of CMV nucleic acids in leucocytes $(7,8,23,24)$ and tissues $(25,26)$ obtained from seronegative patients. WHether this HCMV DNA represents latent virus or defective virus remains unknown.

In summary: a varyity of organs such as spleen, kidney, liver and pancreas contain 
CMV DNA as demonstrated by PCR and dot blot hybridization. The presence of CMV DNA was demonstrated in seropositive and also in seronegative subjects by dot blot DNA hybridization, in situ DNA hybridization and nested PCR. Arterial smooth muscle cells, hepatocytes "tubular and glomerular kidney cells, splenic red pulp cells and pancreatic acinar cells, contain HCMV DNA. The absence of wral gene products in these cells suggests latent rather than low level active infection.

\section{References}

1. Ho M. Cytomegalovirus biology and infectium. New York; Plenum Medical Book Co., 1982.

2. Chou $\mathrm{S}$. Acquisition of donor strains of cytomegalovirus by renal transplant recipients. N Engl J Med 1986;314:1418

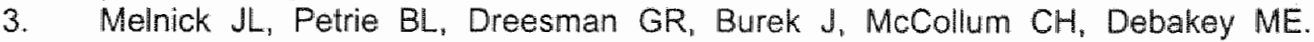
Cytomegalovirus antigen within human arterial smooth muscle cells. Lancot: 1983,ii:644-647.

4. Yamashiroya HM, Ghosh L, Yang R, Robertson L. Herpes viridae in the coronary arteries and aorta of young trauma victims. Am J Pathol 1988;130:71-79.

5. Hendrix MGR, Salimans MMM, van Boven CPA, Bruggeman CA. High prevalence of latently present Cytomegalovirus in arterial walls of patients suffering from grade III atherocierosis. Am J Pathol 1990;136:23-28.

6. Hendrix MGR, Daemen M. Bruggeman CA. Cytomegalovirus nucleic acid distribution within the human vascular tree. Am J Pathol 1991:138:563-567.

7. Bevan IS, Daw RA, Day PJR, Ala FA, Walker MR. Polymerase chain reaction for detection of human cytomegalovirus infection in a blood donor population. $\mathrm{Br} J$ Heamatol 1991:78:94-99

8. Taylor-Wiedeman J Hayhurst GP, Sissons JGP, Sinclair JH. Polymorphonuclear cells are not sites of persistence of human cytomegalovirus in healthy individuals. J Gen Virol 1993;74:265-268

9. Kraat $Y J$, Hendrix MGR, Landini MP, Bruggeman CA. Comparison of four techniques for detection of antibodies to CMV. J Clin Microbiol 1992;30:522-524.

10. van Loon AM, Heessen FWA, van der Logt JThM, van der Veen J. Direct enzyme linked immunosorbent assay that uses peroxidase-labeled antigen for determination of IgM antibody to cytomegalovirus. J Clin Microbiol 1981;13:416-422.

11. Saiki RK, Schauf S, Faloona F. Mullis KB, Horn GT, Ehrlich A, Arnheim N. Enzymatic amplification of B-globin genomic sequences and restriction site analysis for diagnosis of sickle cell anemia. Science 1985;230:1350-1354.

12. Hendrix MGR, Dorman PHJ, Kitslaar $P$, Bosman $F$, Bruggeman CA. The presence of CMV nucleic acids on arterial walls of atherosclerotic and non-atherosclerotic patients. Am. J.Pathol. 1989:134:1151-1157.

13. Lijnschoten $G$, Stals F, Bruggeman CA, Havenith MH, Geraedts JPM. The presence of cytomegalovirus antigens in karyotyped abortions. Am.J.Reprod.Immunol. 1994;32:211-20.

14. Toorkey CB, Carrigan DR. Immunohistochemical detection of an immediate early antigen of human cytomegalovirus in normal tissues. J.Infect.Dis. 1989;160:741. 751.

15. Persing DH. Polymerase chain reaction: trenches to benches. J Clin Microbiol 1990;29:1281-1285

16. Klotman ME, Henry SC, Greene RC, Brazy PC, Klotman ME, Hamilton JD. Detection of mouse cytomegalovirus nucleic acid in latently infected mice by in vitro enzymatic amplification. J linfect Dis 1990;161:220-225

17. Balthesen M, Messerle M, Reddehase MJ. Lungs are a major organ site of 
cytomegalovirus latency and recuurence. J.Virol. 1993;67:5360-5366

18. Collins T, Pomeroy $\mathrm{C}$, Jordan MC. Detection of latent cytomegalovirus DNA in diverse organs of mice. J.I.D. 1993:168:725-9

19. Yuhasz SA, Dissette VB, Cook ML, Stevens JG. Murine cytomegalovirus is present in both chronic active and latent states in persistently infected mice. Virology $1994 ; 202: 272-280$

20. Myerson P, Hackman RC, Nelson JA, Ward DC, McDougal JK. Widespread presence of histologically occult cytomegalovirus. Hum Pathol 1984; 15:430-439.

21. Wu T-C, Lee WA, Pizzorno MC, Au W-C, Chan Y-J et al. Localization of the human CMV 2.7-kb major early B-gene transcript by RNA in situ hybridization in permissive and nonpermissive infections. Am J Pathol 1992;141:1247-1254.

22. Ho M. Epidemiology of Cytomegalovirus infections. Rev Infect Dis 1990;12:S701S710

23. Stanier $P$, Taylor DL, Kitchen AD, Wales N, Tryhorn $Y$, Tyms AT. Persistence of cytomegalovirus in mononuclear cells in peripheral blood from blood donors. $\mathrm{Br}$ Med J 1989;299:897-898

24. Zang et al. Detection of HCMV DNA-RNA and antibody in normal blood donors. J Infect Dis 1995;171:1002-1006

25. Kraat YJ, Hendrix MGR, Wijnen RMH, et al. Detection of latent human cytomegalovirus in organ tissue and the correlation with serological status. Transplant int 1992;5(suppl 1):S613-S616

26. Schonlan $U$, Crombach $M$, Maisch $B$. Assesment of cyomegalovirus DNA and protein expression in patients with myocarditis. Clin Immunol Immunopathol $1993 ; 68: 229-233$ 


\section{CHAPTER 7}

Detection and sequence analysis of the major immediate early and PP150 gene of latent human cytomegalovirus in spleen, liver and kidney tissues of trauma victims

Ron M.G. Hendrix

Eric Beuken

Rob L. Slobbe

Catrien A. Bruggeman

Journal of Medical Virology 1996; 50:193-197. 


\section{Abstract}

The presence of human cytomegalowirus (HCMV) DNA in liver, spleen and kidney samples of HCMV seropositive trauma victims during latency was demonstrated by

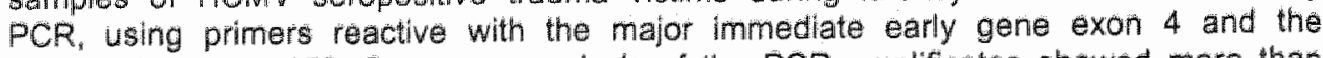
structural gene pp 150. Sequence analysis of the PCR amplificates showed more than $95 \%$ homology with the reference HCMV strain AD169. The few mutations obsened were mastly distributed randomly. In one subject 2 types of the MIE 4 gene were detected, and in another subject two types of the pp150 gene were found, suggesting that different strains of HCMV can be found in organs of the same patient during latency.

\section{Introduction}

In general, human cytomegalovirus (HCMV), a member of the Herpesviridae, infects immunocompetent individuals without causing clinical disease (1). The prevalence of antibodies to HCMV varies from 40 to $80 \%$, depending on the person's socioeconomic status (2). After primary infection, the virus becomes latent but can be reactivated during periods of immunosuppression. and this can lead to life threatening disease (1). The cell type or types that act as a reservoir for the latent HCMV, however, remain(s) obscure. Polymerase chain reaction (PCR) analysis has shown that both peripheral leucokytes $(3,4,5,6)$ and vascular smooth muscie cells $(7,8,9,10)$, can harbor latent HCMV. The data concerning leukocytes are difficult to interpret because several reports demonstrate that HCMV DNA is present not only in seropositive healthy individuals, but also in those who are seronegative $(3,4,5,6)$, whereas in other reports no HCMV DNA could be detected (11). There were great differences in DNA preparation procedures and $P C R$ reaction conditions between these reports, which may contribute to the differences observed. Furthermore, in none of these reports were the sequence of the PCR product analyzed, its identity only being confirmed by hybridization with endlabeled oligonucleotide as probe. Significant sequence variation, as described for clinical HCMV isolates within the gB gene (12, 13), the LS junction (14), and the major immediate early gene (UL123EX4) (15) would therefore go undetected. Sequence analysis can help control an inherent problem of PCR, which is its susceptibilty to artifacts caused by mispriming with genomic DNA, or with DNA from ather Herpesviridae. However. PCR is a powerfull tool for elucidating epidemiological patterns in the pathogenesis of HCMV $(12,13,14)$.

Blood and/or blood products are mostly depleted of leukocytes, and therefore not a major route of HCMV transmission (16), but organ transplantation (1), especially from seropositive donors to seronegative recipients, is a potential route of infection. It therefore seems prudent not only to examine organs available for transplantation such as the liver and kidney, but also other available organs such as the spleen, for the presence of latent HCMV, employing the same techniques used for leucokyte analysis.

In this study, we describe the presence of HCMV nucleic acids, as detected by nested PCR in specimen of spleen, kidney, and liver obtained from previously healthy trauma victims. We also present sequence data for the PCR products, proving that it is indeed HCMV which is detected.

\section{Materials and methods}

\section{Tissue specimen}

Specimen of spleen, kidney, and liver from previously healthy trauma victims were coliected at autopsy, using strict aseptic techniques. All specimens were kept apart and 
were directly placed, in the autopsy room, in $70 \%$ ethanol-phosphate-buffered saline and stored at $4^{\circ} \mathrm{C}$ until use. Autopsy was performed within 12 hours of death. None of the trauma victims had received blood and/or blood products. Eight patients who died of major brain trauma (two females, six males) provided seven spleen samples, eight kidney samples and six liver samples. The mean age of the subjects was 38 years (range 18 to 45 years).

\section{Serology}

Seropositivity for HCMV was determined for all subjects, using a latex agglutination test (CMV-scan, Becton \& Dickinson. Great Brittain) which detects antibodies of both the igG and IgM class (17), and an ELISA (Organon-Teknika, The Netherlands). All sera were collected directly on arrival of the subjects at the hospital.

\section{DNA extraction from tissues}

DNA for PCR analysis was extracted from the ethanol preserved tissues. Small tissue samples were collected in $1.5 \mathrm{~m}$ l polypropylene microcentrifuge tubes. Proteolytic digestion of all samples was carried out overnight at $50^{\circ} \mathrm{C}$ in a mixture of $10 \mathrm{mMT} \mathrm{Tr}-\mathrm{HCl}$ $(\mathrm{pH}=7.5), 5 \mathrm{mM}$ EDTA, $100 \mathrm{mM} \mathrm{NaCl}, 250 \mu \mathrm{g} / \mathrm{ml}$ proteinase $\mathrm{K}$ (Boehringer Mannheim. Germany) and $10 \mathrm{mg} / \mathrm{ml}$ sodium duodecy/sulphate under constant agitation. The DNA was purified by phenol-chloroform extraction and ethanol precipitation and was finally dissolved in $50 \mu$ distilled water. The DNA was quantified spectrophotometrically. To evaluate the possibility of cross-contamination with HCMV DNA during this procedure, every second sample served as a negative control containing herring sperm DNA only and was processed in the same way as the tissue samples.

\section{Oligomer synthesis}

Oligomers were purchased from Eurogentec (Liege, Bellium). One nested set was derived from the HCMV major immediate early gene exon 4 (UL123EX4). The nucleotide sequences of the primers used were: first reaction: A1 5"-ACGAA-TTCGT-AATGAAGCGC-CGCAT-TGA-3' and A2 5'-ACGAG-CTGCA-ATAGT-GACGT-GGGAT-CCA-3'; nested reaction: $B 1$ 5'-ACGAT-TTCTC-TGCAT-GAAGG-TCTTT-GC-3" and B2 5"ACGAG-CTCGT-GGGAT-CCATA-ACAGT-AA-3.' The nested PCR product was 468 basepairs long. A second nested set was derived from the large structural phosphoprotein pp150 (ppUL32(bpp)) (19). The nucleotide sequences of the primers used were: first reaction: C1 5"-GGTGC-TGTTC-AACGA-GCTCA-3" and C2 5'-GGTCC-AGGTT. AAGGT-CGAGC-3; nested reaction: D1 5'-TTGGG-ATACT-ACCGC-GAGCT-3' and D2 5'-TCACG-CAGAA-CATGT-TACGG-3: The nested product was 360 basepairs long. No cloning experiments or other tests had been performed in our laboratory with DNA coding for pp 150 prior to these PCR experiments. All primers were tested for reactivity with DNA sequences stored in the EMBL genebank database and were demonstrated to match stored HCMV sequences only.

\section{Nested polymerase chain reaction}

All PCR experiments were performed under identical reaction conditions. Primer sets were used in seperate reactions, but also in a duplex set-up. The first reaction was performed in $50 \mu$ l. under standard conditions (9).

After 30 cycles (melting: 1 min at $94^{\circ} \mathrm{C}$; annealing: $1 \mathrm{~min}$ at $58^{\circ} \mathrm{C}$; and primer extension: 2 min at $72^{\circ} \mathrm{C}$ ) performed on a Pekin-Elmer-Cetus thermal cycler (Perkin-ElmermCetus, USA), $1 \mu$ of the reaction mixture was transferred to the second reaction tube, contailning the nested primer set under identical reaction conditions to those in the first reaction. After 40 cycles, $10 \mu$ of the second reaction mixture was subjected to electrophoresis on $2 \%$ agarose gels (Seakem GTG, FMC Bioproducts, USA). Amplificates of both MIE-4 and pp150 target genes with the appropriate length were cloned in vector pUC19 
digested with Hindli. One clone containing am amplicon as the insert was subjected to sequence analysis.

\section{Sequence analysis}

Initially, sequence analysis was undertaker with a single clone of each tissue sample, using the dideoxy-chain-termination kit as described by the manufacturer (Pharmacia, Uppsala, Sweden). five of the single clones that demonstrated sequence variation as compared to AD169 were analysed further. For this purpose, a 400 bp fragment of the MIE-4 gene and a 341-bp fragment of the pp150 gene were analyzed.

\section{Fidelity considerations}

To investigate the posibility of misincorporation of nucleotides during PCR due to misreading by the polymerase, 18 separate tissue samples were spiked with purified DNA derived from human embryonic fibrablasts infected with the HCMV reference strain AD169. Nested PCR, cloning, and sequence analysis were carried out as for clinical samples with both nested primer sets.

\section{Prevention of false-positive results}

Pre- and post-PCR handling of samples and buffer preparation were done in different laboratories in order to prevent carry over of reaction products.

\section{Results}

\section{Serology}

All subjects had antibodies against HCMV, as detected by the latex agglutination assay and the ELISA. There was $100 \%$ agreement between both tests.

\section{Nested PCR reaction}

All tissue samples produced HCMV specific reaction products as demonstrated by agarose gel electrophoresis. Samples were positive when tested with MIE-4 or pp150 primers in separate assays, but also when tested in a duplex-PCR set-up. To test for carry over of reaction products, every second sample serving as a negative control containing only herring sperm DNA was also amplified, but none of these controls demonstrated PCR reactivity.

\section{Fidelity considerations}

Of the tissue samples spiked with HCMV reference strain AD169 infected fibroblastderived DNA, a total of 16 independent amplicons of the MIE-4 gene were cloned and sequenced. Of these 16 cloned PCR products, 2 showed one mutation and 2 showed two mutations, all randomly distributed. Thus, 1 in 1066 nucleotides was misincoporated. Sixteen cloned PCR products of the pp150 gene were analyzed the same way. There were six mutations in 6 of the amplicons, giving a misreading rate of 1 in 909 nucleotides.

\section{Sequence anallysis}

Most of the cloned PCR products derived from the tissue samples, had the same sequence as the HCMV reference strain AD169. However, 14/44 (table 2) did show some mutations (table 1). From these variant samples, but also from randomly chosen samples without mutations five additional clones were sequienced. Five additional clones of two tissue samples withoutmutations in the MIE-4 gene being the spleen of patient 1 and the liver of patient 6 , remained without mutations as did additional samples without 
mutations in the pp150 gene, being the spleen of patient 5 and the liver of patient 7 . Only cloned PCR products obtained from the kidney of patient 5 consequently demonstrated mutations at pasitions $263,332,368$, and 389 of the MIE-4 gene. Clones from other organs from the same patient did not show these variations. TWithin the pp 150 gene, the same mutation at pasition 219 was observed in one clone from the kidney and in one clone from the liver from patient 1. The other mutations were located randomly throughout the MIE-4 and the pp 150 amplicons. For the MIE-4 gene, fifty-six cloned PCR products were sequenced and 30 mutations (1 of 745 nucleotides) were observed. For the pp150 gene, seventy-six cloned PCR products were analysed, demonstrating a total of 20 (1 in 1292 nucleotides) mutations.

Table 1. Sequence analysis of six clones obtained from tssue samples showing sequence wariation in the intitial clone tostod.

\begin{tabular}{|c|c|c|}
\hline Tissue & $\begin{array}{l}\text { MiE } 4 \\
\text { mulations }\end{array}$ & $\begin{array}{l}\text { ppyso } \\
\text { mutations }\end{array}$ \\
\hline $\begin{array}{l}\text { Subject } \\
\text { spleen } \\
\text { kidney } \\
\text { liwer }\end{array}$ & $\begin{array}{l}\text { none } \\
3 \times \text { AD 169 } \\
.135(\mathrm{G}) \\
.257(\mathrm{~T}) \\
.306(\mathrm{~A}) \\
5 \times \mathrm{AD} 169 \\
.175 \text { (T) } 362 \text { (G) } 363 \text { (G) } 384 \text { (A) }\end{array}$ & $\begin{array}{l}5 \times \mathrm{AD} 169 \\
32 \|(\mathrm{T}) \\
5 \times \mathrm{AD} 169 \\
211 \text { (A) } 235 \text { (G) } \\
2 \times \mathrm{AD} 169 \\
59 \text { (G) } 140 \text { (C) } \\
227 \text { (A) } 106 \text { (T) } \\
21 \text { (G) } 25 \text { (C) } 318 \text { (A) } 281 \text { (A) } 211(\mathrm{~A})\end{array}$ \\
\hline $\begin{array}{r}\text { Subject } 2 \\
\text { spleen }\end{array}$ & none & $\begin{array}{l}5 \times \text { AD } 699 \\
.113(A)\end{array}$ \\
\hline $\begin{array}{l}\text { Subject } 5 \\
\text { spleen } \\
\text { kidney } \\
\text { lver }\end{array}$ & $\begin{array}{l}4 \times A D 169 \\
176(\mathrm{G}) \\
212 \text { (C) } \\
263 \text { (C) } 332 \text { (A) } 368 \text { (A) } 389 \text { (A) } \\
360 \text { (G) } 332 \text { (A) } 368 \text { (A) } 389 \text { (A) } \\
94 \text { (T) } 130 \text { (A) } 141 \text { (C) } \\
211 \text { (G) } 263 \text { (C) } 332 \text { (A) } 360 \text { (G) } 368 \text { (A) } 369 \text { (A) } \\
170 \text { (G) } 180 \text { (A) } \\
234 \text { (C) } \\
5 \times A D 169 \\
275 \text { (G) }\end{array}$ & $\begin{array}{l}\text { nane } \\
5 \times \text { AD } 169 \\
4 \times A D 169 \\
157(G) \\
160 \text { (A) }\end{array}$ \\
\hline $\begin{array}{l}\text { Subject } 6 \\
\text { kidney } \\
\text { tumer }\end{array}$ & $\begin{array}{l}\text { none: } \\
\text { noine }\end{array}$ & $\begin{array}{l}5 \times \text { AD169 } \\
\text { 230 (T) } \\
5 \times \text { AD169 } \\
\text { (A) (A) }\end{array}$ \\
\hline $\begin{array}{r}\text { Subject } 7 \\
\text { splesen } \\
\text { kidmey }\end{array}$ & $\begin{array}{l}\text { mone } \\
\text { none }\end{array}$ & $\begin{array}{l}\text { 5* AD169 } \\
=16(\mathrm{~A}) 21(\mathrm{~T})\end{array}$ \\
\hline
\end{tabular}

"none means that in the initial clone no variation in the sequences were detectable.

\section{Discussion}

In recent years it has been shown, that latent human cytomegalowirus (HCMV) is present in leucocytes $(3,4,5,6)$ and the arterial wall $(7,8,9,10)$ of healthy HCMV seropositive individuals. In this report we demonstrate by nested PCR, that HCMV is 
also present in the kidney, spleen, and liver of previously healthy trauma victims. We also present sequence analysis data which demonstrate a high sequence homology between the HCMV present in these organs and the reference strain AD 169 , indicating that HCMV DNA and not DNA of another (Herpes)ivisus is detected.

The data presented in this study confirm the observation that HCWV DNA is present in a variety of organs obtained from HCMV seropositive individuals $(20,21,22)$. Also in the mouse CMV model, a wide tissue distribution of latent MCMV has been demonstrated $(24,25)$.

Fidelity analysis of the procedures used demonstrated that 1 in 1066 nucleotides for MIE-4 and 1 in 909 nucleotides for pp150 were misincorporated when starting from AD169 sequences. This means that for MiE-4 a total of 21 mutations and for pp 150 a total of 28 mutations could be expected on the basis on the estimated fidelity and the total number of fragments sequenced. The total number of mutations observed for MIE4 and pp150 (30 and 20 respectively) is consistent with the estimated fidelity, so they probably do not represent true mutations. The random distribution of these mutations further adds to this conclusion. Other reports also demonstrate minor sequence variations within the MIE-4 gene (15), but provide no fidelity data. None of the observed mutations produces stop signals as analyzed by the PC gene program. The high degree of homology between the amplified fragments and the reference strain AD169 demonstrates that HCMV DNA is indeed detected, and the numerous negative controls exclude contamination with exogenous DNA.

The repeatedly observed mutations of the MIE-4 gene in the kidney of subject 5 and of the pp150 gene in the kidney and liver of subject 1 probably represent true mutations. Two types of the MIE-4 gene were present in the kidney of subject 5, and two types of the pp 150 gene were detected in tissues from subject 1 . Whether these two types of genes represent two different HCMV strains, however, is not known. Only isolation and propagation of HCMV from these organs can answer this question. During active infections, viral excretion of more than one strain has been demonstrated $(23,24,25,26)$, but this phenomenom has not been described during latency until now.

The presence of HCMV DNA organs that are used for transplantation and in the spleen suggests that the spleen can be used to screen for HCMV DNA by PCR, prior to transplantation. Seronegative organ recipients of organs containing two types of genes can then be carefully investigated for the emergence of HCMV strains carrying the same mutations.

\section{References}

1. Ho M. Cytomegalovirus biology and infection. New York; Plenum Medical Book Co. 1982.

2. Yow MD, Williamson DW, Leeds 1., Thompson P, Woodward RM, Walmus BF. Lester JW, Six HR, Griffiths PD. Epidemiological characteristics of cytomegalovirus infection in mothers and their infants. Am J Obstet Gynecol 1988;158:1189. 1195.

3. Stanier P, Taylor DL, Kitchen AD, Wales $N$ "Tryhorn $Y$, Tyms AS. Persistence of cytomegalovirus in mononuclear cells in peripheral blood from blood donors. $\mathrm{Br}$ Med Journ 1989,299:897-898.

4. Bevan IS, Daw RA, Day PJR, Ala FA, Waker MR. Polymerase chain reaction for detection of human cytomegalovirus infection in a blood donor population. $\mathrm{Br} \mathrm{J}$ Haematol 1991,78:94-99.

5. Taylor-wiedeman J, Sissons JGP, Borysiewicz LK, Sinclair JH. Monocytes are a major site of persistence of human cytomegalovirus in peripheral blood mononuclear cells. J Gen Virol 1991;72; 2059-2064 
6. Taylor-Wiedeman J, Hayhurst GP, Siisons JGP, Sinclair JH. Polymorphonuclear cells are not sites of persistence of human cytomegalovirus in healthy individuals. J Gen Virol 1993:74:265-268.

7. Melnick JL, Petrie $\mathrm{BL}$, Dreesman $\mathrm{GR}$, Burek J.McCollum $\mathrm{CH}$, Debakey ME. Cytomegalovirus antigen within human arterial smooth muscle cells. The Lancet $1983 ; i i: 644-647$.

8. Yamashiroya HM, Ghosh L, Yang R, Robertson L, Herpes viridae in the coronary arteries of young trauma victims. Am J Pathol 1988;130:71-79.

9. Hendrix MGR, Salimans MMM, van Boven CPA, Bruggeman CA. High prevalence of latently present cytomegalovirus in arterial walls of patients suffering from grade III atherosclerosis. Am J Pathol 1990;136:23-28.

10. Hendrix MGR, Daemen M, Bruggeman CA. Cytomegalovirus nucleic acid distribution within the human vascular tree. Am J Pathol 1991:138:563-567.

11. Bitch A, Kirchner H, Dupke R, Bein G. Failure to detect human cytomegalovirus DNA in peripheral blood leucocytes of healthy blood donors by the polymerase chain reaction. Transfusion 1992;32: 612-617.

12. Zhang LJ, Hauff $\mathrm{P}$. Rutherford $\mathrm{C}$, Churchil WH, Crumpacker CS. Detection of human cytomegalovirus DNA, RNA and antibody in normal donor blood. I Infect Dis 1995; 171:1002-1006.

13. Chou S, Dennison KM. Analysis of intersirain variation in cytomegalovirus glycoprotein $B$ sequences encoding neutralization related epitopes. J I D 1991:163:1 229-1234.

14. Fries BC, Chou S, Boeckh M, Torok-Storb B. Frequency distribution of cytomegalovirus envelope glycoprotein genotypes in bone marrow transplant recipients. J Infect Dis 1994;169:769-774.

15. Zaia JA, Gallez-Hawkins G, Churchill MA, Morton-Blackshere A. Pande H, Adler SP. Schmidt GM, Forman SJ. Comparative analysis of human cytomegalovirus alpha-sequences in multiple clinical isolates by using PCR and RFLP analysis. J Clin Microbiol 1990;28:2602-2607.

16. Chou $\mathrm{S}$. Effect of interstrain variation on diagnostic DNA amplification of the cytomegalovirus major immediate early region. J Clin Microbiol 1992;30:23072310.

17. Verdonck LF, de Graan-Hentzen YCE, Dekker AW, Mudde GC, de Gast GC. Cytomegalovirus seronegative platelets and leucocyte poor red bload cells from random donors can prevent primary cytomegalovirus infection after bone marrow transplantation. Bone Marrow Transplant 1987;2:73-78.

18. Kraat $Y \Downarrow$, Hendrix MGR, Landini MP, Bruggeman CA. Comparison of four techniques for detection of antibodies to CMV. J Clin Microbiol 1992;30:522-524.

19. Akrigg A, Wilkinson GWG, Oram JD. The structure of the major immediare early gene of human cytomegalovirus strain AD169. Vir Res 1986;2:107-121.

20. Jahn G, Kouzarides T, Mach M, Scholl BC, Plachter B, Traupe B, Freddie E, Satchwell SC. Fleckenstein B, Barrel BG. Map position and nucleotide sequence of the gene for the large structural phosphoprotein of human cytomegalovirus. J viral 1987;61:1358-136721.

21. Naoumov NV, O'Grady JG, Portman BC. Alexander GJM ${ }^{\prime}$ Aldis $P$, Williams R. Rapid diagnosis of cytomegalovirus infection by in situ hybridization in liver grafts. The Lancet 1988;1(1899):1361-1364.

22. Arndt $R$, Dittmer $R$, Harfmann $P$, et al. Virus detection by DNA in situ hybridization in renal transplantation - a new perspective for differential diagnosis of virus infection versus rejection. Transplant Proc 1990; 22:1803-1804.

23. Myerson P, Hackman RC, Nelson JA, Ward DC, McDougal JK Widespread presence of histologically occult cytomegalowirus. Hum Pathol 1984;15:430-439.

24. Klotman ME, Henry SC, Greene RC, Brazy PC, Klotman PE, Hamilton JD. 
Detection of mouse cytomegalovirus nucleic acid in latently infected mice by in vitro enzymatic amplification. I Infect Dis 1990;161:220-225.

25. Collins T. Pomeroy $C_{*}$ Jordan MC. Detection of latent cytomegalowirus DNA in diverse organs of mice. J Infect Dis 1993:168:725-729.

26. Chou $\mathrm{S}$. Reactivation and recombination of multiple cytomegalovirus strains from individual organ donors. J Infect Dis 1989;160:11-15.

27. Shen C-Y, Chang S-F, Chao M-F. Huang E-S, Wu C-W. Identification of a serial change in recurrent cytomegalovirus strains in a healthy child by polymerase chain reacion. J Infect Dis 1993;168:252-253.

28. Spector SA, Hirata $K K$, Neuman TR. dentification of multiple cytomegalovirus strains in homosexual men with acquired immunodeficiency syndrome. I Infect Dis $1984 ; 150: 953-956$.

29. Collier $\mathrm{AC}$, Chandler $\mathrm{SH}$. Handsfield HH, Corey L, McDougall JK. Identification of multiple strains of cytomegalowirus in homosexual men. J Infect Dis 1989; 159 : $123-126$. 


\section{CHAPTER 8}

\section{General discussion}

1. Introduction

2. HCMV in atherosclerosis

3. Detection of HCMV in human tissules

4. Conclusions

5. References 


\section{Introduction}

Human Cytomegalowirus (HCMV) a member of the Herpesvirusgroup (1) is ubiquitous in humans (2). It is generally accepted that after primary infection the HCMV remains present in the human body in a latent state $(1,2,3,4,5)$. Although the concept of HCMV latency has been recognized some decades ago, little is known about the cell type or types that act as a reservoir for the latent wirus. The possibility that the blood leucocyte contained latent HCMV was already considered in 1951 (6). HCMV was presumed to be present in these cells in an unidentified form from which it could only reactivate after allogeneic stimulus (7). Later on a definition of the latent state of $\mathrm{HCMV}$ was proposed by Banks and Rouse (8). They described it as a persistent infection in which the complete viral genome is present in a cell but no or very limited viral gene expression is found. Infectious viral particles are not produced. The capacity to reactivate from this latent state into an active infection was included in this definition by Fraser (9).

Since the introduction of molecular biological techniques, HCMN DNA and/or RNA was detectable in a variety of human tissues, like: Kaposi's sarcoma (10), carcinoma of the cervix (11, 12), prostate (13), and colon (14) angioimmunoblastic lymphadenopathy (15). and in atherosclerotic vascular walls $(16,17,18,19)$. The detection of HCMV nucleic acids in these laesions could suggest a role for this wirus in the pathogenesis of these diseases, but it might just as well reflect a localization of latent HCMV. HCMV DNA could also be detected in leucocytes obtained from healthy blood donors $(20,21,22)$ but data are conflicting since other investigators failed to detect HCMV DNA in these individuals $(23,24)$.

In this section we like to discuss our data concerning the presence of HCMV in atherosclerotic and mon-atherosclerotic arterial walls and in various tissues obtained from healthy individuals, and compare our data with data from other groups.

\section{HCMV in atherosclerasis}

Studies with an avian herpeswirus, Marek's disease virus (MDV) in chickens demonstrated that an extensive atherosclerosis-like disease developed after infection with this virus (25). By in situ DNA hybridization. MDV nucleic acids could be detected in the vascular wall of infected chickens (25). Also in humans the presence of herpesviruses could be demonstrated in vascular walls obtained from patients undergoing reconstructive vascular surgery for occlusive atherosclerotic disease $(15,26)$. Both herpes simplex and HCMV were detected by in situ DNA hybridization $(15,26)$. Using an explant technique. HCMV antigens and DNA could be detected in smooth muscle cells cultured from atherosclerotic wascular tissues $(16,17)$ However no infectious virus could be recovered from these smooth muscle cell cultures. The detection of herpes viral nucleic acids including HCMV in the coronary artery and aorta of young trauma victims only demonstrating very early signs of atherosclerotic degeneration (19) suggested a role for these viruses in the development of atherosclerosis $(27,28)$. However, interpretation of these results in view of the pathogenesis of atherosclerosis is difficult.

A direct association between vasculopathy and HCMV comes from studies with human heart transplant recipients. In these studies a high rate of accelerated allograft arteriosclerosis was observed in HCMV seropositive recipients $(29,30,31,32)$. The development of a rat-model in which CMV infection doubles the rate of allograft atherosclerosis (33) opened the opportunity to study the effect of antiviral therapy on the development of allograft atherosclerosis. It was demonstrated that early treatment of CMV infected mice with DHPG (ganciclovir) could indeed prevent CMV infection-enhanced allograft 
atherosclerosis $(34,35$ ) The observation that triple drug immunosuppression reduced CMV infection-enhanced allograft arteriosclerosis suggests that other factors than CMV infection play a role in the pathogenesis of this disease (36).

Also in immunocompetent patients restenosis of coronary arterles due to neointimal hyperplasia and arterial remodeling commonly occurs after coronany angioplasty and atherectomy $(37,38)$. In this group of patients, prior infection with HCMN has been demonstrated to be a strong independent risk factor for restenosis (39), suggesting a rolle for HCMV in the pathogenesis of this disease. A possible explanation for this phenomenon was found in the inhibition of the tumor suppressor protein p53 by a HCMV protein IE84 transcribed from the IE-1 and IE-2 genes (UL123) (40).

Some epidemiological data also suggest a role for HCMV in the pathogenesis of atherosclerotic disease of non-cardiac arteries. A high level of HCMV antibodies could be found in patients requiring vascular surgery (41). Also a graded relation between the levels of HCMV antibodies and the ammount of intimal-medial thickening of the carotid artery could be demonstrated (42). However prior HCMV infection was not a risk factor for the development of primary coronary artery atherosclerosis (43).

Until now, no epidemiological studies have been performed using molecular techniques to describe the presence of HCMV DNA in arterial walls.

In our studies (chapter 3) we were able to demonstrate by PCR that $90 \%$ of the vascular samples obtained from patients undergoing reconstructive vascular surgery and representing end stage disease, contained HCMV DNA. However, $50 \%$ of the vascular samples obtained at autopsy from age and sex matched controls with no macroscopical signs of atherosclerosis did also contain HCMV DNA (44). In further studies (chapter 5) we found that HCMV DNA could be detected in all major elastic arteries, including pulmonary arteries which were microscopically free of atherosclerotic degeneration (45) Also in individual patients showing advanced atherosclerotic disease of at least 6 main vessels, arteries even not having intimal thickening were present and in all these arteries HCMV DNA could be detected (45). By using semi quantitative dof blot DNA hybridization (chapter 5) we were able to demonstrate that approximately 2 or less viral genomic equivalents (VGE) were present per 2500 human genomic equivalents (HGE) (45). There were no differences observed in the number of VGE per HGE present in arteries with or without atherosclerotic changes. Based on these observations we did not find a correlation between the presence of HCMV and atherosclerosis.

The presence of HCMV DNA in the vessell wall as described (chapters $3,4,5$ ) is in accordance with most of the criteria for wiral latency as defined by Banks and Rouse $(8$, 9) in which they describe viral latency as a persistent infection in which the complete viral genome is present but no or very limited viral gene expression is found; no infectious viral particles are produced, and the virus still must have the capacity to reactivate from this latent state into an active infection.

In our studies (chapter $2,3,4$ ) we always used 2 different PCR targets to detect HCMV DNA in tissue samples. Since these PCR's were always simultaneously positive we concluded that the whole viral genome is present in the arterial samples. Using in situ hybridization with a probe reactive with immediate early sequences UL 122, UL123, UL125, LL126) (chapter 3,4) we could demonstrate that a high number of arterial samples were positive. However, using a probe reactive with late (UL83) sequences only a limited number of samples showed a positive in situ hybridization (44, 46). These findings may suggest that HCMV transcription is limited to IE-genes and is not extended to late genes. Recently at has been demonstrated that also in bone marrow progenitor cells obtained from healthy seropositive donors the transcriptional program is also limited to IE-genes (34).

Despite numerous attempts we were not able to culture HCMV from the arterial samples. All these observations led us to the conclusion that the HCMV nucleic acids present in the human vascular wall represent latent virus. However we could not meet 
the last criterium in the definition of HCMV latency since we could not demonstrate the capacity of this latent $\mathrm{HCMV}$ to reactivate into an active infection.

\section{Detection of HCMV in human tissues}

Our ability to detect nucleic acids of latent HCMV in arterial walls of healthy persons (chapter $3,4,5$ ) suggested that in situ hybridization and PCR provide powerful tools for the detection of HCMV in other tissues. To study the presence of latent HCMV in other organs, only healthy subjects with no medical histories, like trauma victims which are available for donor nephrectomy, or individuals dying of sudden cardiac arrest were selected to provide tissue samples. To exclude the possibility of primary HCMV infection serum samples should be negative for HCMV-IgM antibodies. Until now only few reports meet these criteria. In a study from Toorkey et al (47) tissue sections obtained at autopsy from patients with trauma as the cause of death were investigated for the presence of HCMV. HCMV antigen was detected by immunohistochemical techniques using a monaclonal antibody reactive with a $68 \mathrm{kDa}$ immediate early protein. HCMV antigens were detected in tubular and glomerular epithelial cells, cells of Bowmann's capsule, and endothelial cells of the kidney. Hepatocytes, kupfer cells, and endotheliall cells of the liver contained HCMV antigens. In the lung, HCMV reactive cells consist of bronchial and alveolar epithelial cells, alveolar macrophages, fibroblasts and endothelial cells. In the spleen. T lymphocytes, macrophages, fibroblasts and endothelial cells were reactive, and fimally in the brain, astrocytes and endothelial cells were HCMV positive. These results, however, could only be produced using a single batch of a monoclonal antibody reactive with a $72-\mathrm{kdDa}$ antigen of HCMV. By using another monoclonal antibody also reactive with a $72-\mathrm{KDa}$ immediate early antigen of HCMV or a goat antiserum raised against purified HCMV, they could not reproduce the results obtained with the first batch of antibody. The authors suggest that epitopes reactive with these last antibodies are destroyed be formalim. In our studies (chapter 5) HCMV was detected in tissues obtained from patients meeting the above criteria (48). HCMV was detected by in situ hybridization and PCR. Using in situ hybridization with a probe reactive with immediate early sequences of HCMV (UL122, UL123 UL125, UL126), we could demonstrate the presence of HCMV mucleic acids in various cell types. In the spleen, the red pulp was positive. In the kidney, HCMV positive cells were epithelial cells of the tubulus and cells of the glomerulus. Pancreatic cells showing hybridization were acinar cells and withim the liver. HCMV containing cells were mainly hepatocytes. Our findings (48) are in agreement with the immunohistochemical finding of Toorkey et al (60) and demonstrate a wide tissue distribution of HCMV during latent infection. This distribution is similar to the tissue distribution as observed during active HCMV infection $(49,50,51$, $52,53,54)$.

We could also demonstrate the presence of HCMV DNA by PCR with 2 primer sets reactive with inmediate early and late sequences of the virus (chapter 4, 5). Most reports using PCR for HCMV DNA detection confirm the identity of the PCR products by hybridization with a short, end-labelled oligonucleotide as probe. It therefore remains posible that significant sequence variation as described for the gB gene $(55,56)$, the LS-junction (57) but also the immediate early gene (UL123EX4) (58) which is currently in use as PCR target remains undetected. Sequence analysis can detect these variations but can also prove that indeed HCMV DNA is detected. In our studies (chapter 5) we did perform a sequence analysis of the amplificates produced by nested PCR of spleen. kidney and liver tissues obtained from trauma victims (59). Very few mutations were observed both in the immediate early (UL123) and in the PP150 (UL32) PCR targets as compared to the HCMV prototype strain AD169, demonstrating that indeed a patient-derived wild type HCMV is detected. The few mutations that were observed were randomly distributed over the amplified gene segment and did not seem 
to produce stopcodons. The consistent finding of two genotypes for the immediate early gene in one individual and for the PP150 gene segment in another individual (59) possibly reflects latent infection with two HCMV strains. Also during active HCMV infection, viral excretion of more than one strain has been demonstrated $(60,64,62$, 63). Based on these observations we conclucle that indeed HCMV DNA is detected and that during latency HCMV shows a wide tissue distribution. The HCMV tissue distribution is in sharp contrast with that of two other members of the herpes family: herpes simplex, which is only latently present in neurons of the spinal ganglia, and Epstein Barr virus latency which is only latently present in B-cells (1).

\section{Conlusions}

Latent HCMV shows a wide tissue distribution and is present in the splenic red pulp, in epthelial cells of the tubulus and cells of the glomerulus, in vascular smooth muscle cells, in pancreatic acinar cells and within the liver. HCMV-containing cells were mainly hepatocytes. This pattern closely resembles the wide distribution observed during active infection. Latent virus can be detected by in situ hybridization using probes reactive with immediate early sequences but not late sequences suggesting a very limited transcriptional program during latency.

The consistent finding that in a single individual, two HCMV genotypes are present suggests that during life not only infections with more than one HCMV strain are possible, but that these strains can also establish a latent infection within one host.

This widespread presence of HCMV DNA in normal tissues and also in atherosclerotic tissues cannot be interpreted in view of the pathogenesis of atherosclerosis since the presence of viral DNA possibely only reflects latent virus. However, the recent finding that also during latency HCMV IE sequences are transcribed and that IE-gene products can interfere with the tumor repressor protein p53 still opens intriguing possibilities for further studies onto the role of HCMV in the pathogenesis of diseases such as atherosclerosis, transplant arteriosclerosis and restenosis.

\section{Refrences}

1. Fields BN, Knippe DM, Howley PM. Virology 2. Philadelphia; Lippincot Raven publishers 1996.

2. Ho M. Cytomegalovirus biology and infection. New York; Plenum Medical Book Co. 1991.

3. Jordan MC. Latent infection and the elusive cytomegalovirus. Rev.lnfect.Dis. $1983 ; 5: 205-215$.

4. Stevens JG. Human herpeviruses: a consideration of the latent state. Microbiol.Rev. 1989:53:318-332.

5. Bruggeman CA, Cytomegalovirus and latency: an overview. Vichows Archiv B. Cell.pathol. 1993;64:325-33.

6. Wyatt JP, Hemsath FA, Soash MD. Disseminated cytomegalic inclusion disease in an adult with primary refractory anaemia and transfusional sclerosis. Report of a case. Am. J. Clin.Path. 1951,21:50-55.

7. Jordan MC. Latent infection and the elusive cytomegalovirus. Rev.Infect.Dis. $1983 ; 5: 205-215$.

8. Banks AB, Rouse BT. Herpeswiruses - immune escape artists? Clin.Infect.Dis. $1992 ; 14: 933-941$.

9. Fraser NW, Block TM, Spivack JG. The latency-associated transcripts of herpes simplex virus: RNA in research and function. Virol. 1992:191:1-8.

10. Boldogh I. Beth E, Huang ES, Kyalwazi SK, Giraldo G. Kaposi's sarcoma: detection of CMV DNA, CMV RNA, and CMNA in tumor biopsies. Int.J.Cancer 1981;28:- 
$469-474$.

11. Huang E-S. Boldogh 1, Mar EC.Evidence for possible association with human cancer. In: Phillips LA, ed. Viruses associated with human cancer. New York: Marcel Dekker 1983:161-194.

12. Huang E-S, Mar EC. Boldogh 1, Baskar J. The oncogenecity of human cytomegalovirus. In Plotkin SA, Michelson S, Pagano JS, Rapp F, eds. CMV: pathogenesis and prevention of human infections. Birth defects. original articles series "Vol. 20 , no 1. March of Dimes Bith Defects Foundation. New York: Alan R. Liss, 1984:$193-211$.

13. Geder L. Sanford EJ, Rohner TJ, Rapp F. Cytomegalovirus and cancer of the prostate: in vitro transformation of human cells. Cancer Treat. Rep. 1977;61:139146.

14. Huang E-S, Pagano JS. Cytomegalovirus DNA and adenocarcinoma of the colon: evidence for latent viral infection. Lancet 1978;1:957-960.

15. Yu A-M, Song R-L, Yu Z, Chen Y-P, Wang F-Z Na L-X, Xie G-L Yang M-J. detection of human cytomegalovirus antigen and DNA in lymph nodes and peripheral blood mononuclear cells of patients with angioimmunoblastic lymphadenopathy with dysproteinemia. Arch.Pathol.Lab.Med. 1992;116:490-494.

16. Melnick JL. Petrie BL, Dreesman GR, Burek J McCollum CH, Debakey ME. Cytomegalovirus antigen within human arterial smooth muscle cells. Lancet; 1983, ii:644-647.

17. Petrie BL, Melnick JL, Adam E, Burek J McCollum CH. DeBakey ME. Nucleic acid sequences of cytomegalovirus in cells cultured from human arterial tissue. J.Infect Dis. 1987;155:158-159.

18. Melnick JL, Hu C, Burek J, Adam E. Debakey ME. Cytomegalowirus DNA in arterial walls of patients with atherosclerosis. J. Med. Virol. 1994;42:170-174.

19. Yamashiroya HM, Ghosh L, Yang $R$, Robertson $L$, Herpes viridae in the coronary arteries of young trauma victims. Am. J. Pathol. 1988;130:71-79.

20. Stanier P. Taylor DL, Kitchen AD, Wales $N$, Tryhorn $Y$, Tyms AS. Persistence of cytomegalovirus in mononuclear cells in peripheral blood from blood donors. Br.Med.J. 1989;299:897-898.

21. Bevan IS, Daw RA, Day PJ, Ala FA, Walker MR. Polymerase chain reaction for the detection of human cytomegalowirus infection in a blood donor population Br. J. Haematol. 1991;78:94-99.

22. Taylor-Wiedeman J. Sissons JGP. Borysiewics LK, Sinclair JH. Monocytes are a major site of persistence of human cytomegalovirus in peripheral blood mononuclear cells. J.Gen.Virol. 1991:72:2059-2064.

23. Bitch A, Kirchner H, Dupke R, Bein G. Failure to detect human cytomegalovirus DNA in peripheral blood leucocytes of healthy bloos donors by the polymerase chain reaction. Transfusion 1992;32:612-617.

24. Urushibara N, Kwon KW. Takahashi TA, Sekiguchi S. Human cytomegalovirus DNA is not detectabile with nested double polymerase chain reaction in healthy blood donors Vox Sang 1995;68:9-14.

25. Fabricant CG, Fabricant $₫$, Milnick CR, Litrenta MM. Herpes virus-induced atherosclerosis in chickens. Fed.Proc. 1983;42:2476-2479.

26. Benditt EA, Barret T, MCDougall JK. Viruses in the etiology of atherosclerosis. Proc. Natl.Acad.Sci. Usa 1983;80:6386-6389.

27. Melnick JL, Adam E. DeBakey ME. Possible role of cytomegalowirus in atherogenesis. J.A.M.A. 1990;263:2204-2207.

28. Hajjar DP. Viral pathogenesis of atherosclerosi. Impact of molecular mimicry and viral genes. Am.J.Path. 1991:139:1195-1211.

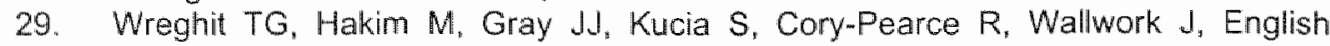
TAH. A detailed study of cytomegalovirus infections in the first 160 heart/ung 
transplant recipients at Papworth Hospital, Cambridge England. Transplant. Proc. 1987:19:2495-2496.

30. Grattan MT, Moreno-Gabral CE, Staines VE, Over PE, Stinson EB, Shumway NE. Cytomegalovirus infection is associated with cardiac allograft rejection and atherosclerosis. JAMA 1989;261:3561-3566.

31. McDonald K, Rector TS, Braunlin TA, Kubo SH, Olvari MT. Association of coronary artery disease in cardiac transplant recipients with cytomegalovirus infection. Am.J.Pathol. 1989;64:359-362.

32. Zhou YF, Leon MB, Waclawiw MA, Popma $J$. YU ZX. Finkel T, Epstein SE. Association between prior cytomegalovirus infection and the risk of restenosis after coronary atherectomy. N. Engl. J. Med. 1996;29:624-768.

33. Lemstrom KB, Bruning JH, Bruggeman CA, Lautenschlager IT, Hayry PJ. Cytomegalowirus infection enhances smooth muscle cell proliferation and intimal thickening of rat aortic allografts. J.Clin. Invest. 1993;92:549-558.

34. Lemsirom KB, Bruning $J H$, Bruggeman CA. Koskinen PK, Aho PT, Yilmaz $S$, Lautenschlager IT, Hayry PJ. Cytomegalovirus infection-enhanced allograft arteriosclerosis is prevented by DHPG prophylaxis in the rat. Circulation 1994;9$0: 1969-1978$.

35. Lemstrom $K$, Sihvola $R$, Bruggeman $C A$, Haygry $P$, Koskinen $P$. Cytomegalovirus infection-enhanced cardiac allograft vasculopathy is abolished by DHPG prophylaxis in the rat. Circulation 1997;95:1614-2616.

36. Lemstrom KB, Bruning JH, Bruggeman CA, Lautenschlager IT, Hayry PJ. Triple drug immunosuppression significantly reduces immune activation and allegraft arteriosclerosis in cytomegalovirus-infected rat aortic allografts and induces early latency of viral infection. Am.J.Pathol. 1994;144:1334-1347.

37. Serruys PW, Luyten HE, Beatt KJ. Incidence of restenosis after succesful coronary angioplasty: a time related phenomenon " a quantitative angiographic study in 342 consequtive patients at $1,2,3$, and 4 month. Circulation 1988,77:361-71.

38. Faxan DP, Currier JW. prevention of post-PTCA restenosis. Ann.N.Y.Acad.Sci. 1995;748:419-27.

39. Zhou YF, Leon MB, Waclawiw MA, Popma JJ, Yu ZX, Finkel T, Epstein SE. Association between prior cytomegalovirus infection and the risk of restenosis aftet coronary atherectomy. N.Eng. J.Med. 1996;335:624-630.

40. Speir E, Madali R, Huang ES, Leon MB, Shawl F. Finkel T. Epstein SE. Potential role of human cytomegalovirus and $p 53$ interaction in coronary restenosis. Science 1994;265:391-394.

41. Adam E, Melnick لlL, Probstfield JL, Petrie BL, Burek J, Balley KR, McCollum CH, DeBakey ME. High level of cytomegalovirus antibody in patients requiring vasicular surgery for atherosclerosis. Lancet 1987;2:291-293.

42. Nieto FJN, Adam E, Sorlie P. Farzadegan H, Melnick JL, Comstock GW, Szklo $M$. Cohort study cytomegalovirus infection as a risk factor for carotid intimal. medial thickening, a measure of subclinical atherosclerosis. Circulation 1996:94:$922-927$

43. Adler SP, Hur JK, Wang JB, Vetrovec GW. Prior infection with cytomegalovirus is not a major risk factor for angiographically demonstrated coronary artery atherosclerosis. J.Infect.Dis $1998 ; 177: 209-212$.

44. Hendrix MGR, Salimans MMM, van Boven CPA, Bruggeman CA. High prevalence of latently present cytomegalovirus in arterial walls of patients suffering from grade III atherosclerosis. Am.J.Pathol. 1990;136:23-18.

45. Hendrix MGR, Daemen M, Bruggeman CA. Cytomegalovirus nucleic acid distribution withim the human vascular tree. Am.J.Pathol. 1991;183:563-567.

46. Hendrix MGR, Dorman PHJ, Kitslaar P, Bosman F, Bruggeman CA. The presen- 
ce of CMV nucleic acids on arterial walls of atherosclerotic and non-atherosclerotic pattents. Am.J.Pathol. 1989;134:1151-1157.

47. Toorkey CB. Carrigan DR. Immunohistochemical detection of an immediate early antigen of human cytomegalovirus in normal tissues. Jinfect.Dis. 1989;160:741751.

48. Hendrix MGR, Wagenaar M, Slobbe R, Bruggeman CA. Widespread presence of cytomegalovirus DNA in tissues of previously healthy trauma victims. J. Clin. Pathol. 1997:50:59-63.

49. Andersen CB. Detection of cytomegalovirus-infected cells in autopsy material by in situ hybridization. A.P.M.I.S. 1990;98:363-368.

50. Gnann JW, Ahlmen J, Svalander $C$, Olding L, Oldstone MBA, Nelson JA. Inflammatory cells in transolanted kidneys are infected by human cytomegalowirus. A.J.P $1988 ; 132: 239-248$.

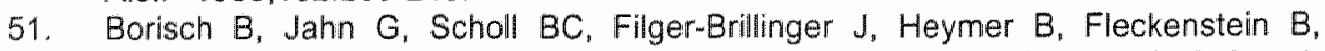
Muller Hermelink HK. Detection of human cytomegalovirus DNA and virall antigens in tissues of different manifestations of CMV infection. Virch.Arch.B.Cell.P. athol. 1988,55:93-99.

52. Wolber RA, LLoyd RV. Cytomegalovirus detection by nonisotopic in situ DNA hybridization and viral antigen immunostaining using a two-color technique. Hum.Path. 1988;19:736-741.

53. Meyerson D. Hackman RC, Nelson JA, Ward DC, McDougall JK. Widespread presence of histologically occult cytomegalovirus. Hum.Path. 1984;15:430-439.

54. Weiss LM, Movahed LA, Berry GJ, Billigham ME. In situ hybridization studies for vitral nucleic acids in heart and lung allograft biopsies. A.J.P. 1990;93:675-679.

55. Chou $S$, Dennison KM. Analysis of interstrain variation in cytomegalovirus glycoprotein B sequences encoding neutralization related epitopes. J I D 1991:163:1229-1234.

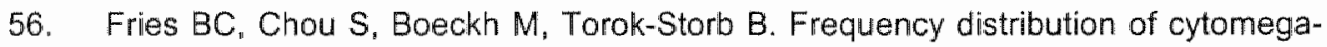
lovirus envelope glycoprotein genotypes in bone marrow transplant recipients. J infect Dis 1994:169:769-774.

57. Zaia JA, Gallez-Hawkins G, Churchill MA, Morton-Blackshere A, Pande $H_{\text {, Adler }}$ SP, Schmidt GM, Forman SJ. Comparative analysis of human cytomegalovirus alpha-sequences in multiple clinical isolates by using PCR and RFLP analysis. Clin Microbiol 1990;28:2602-2607.

58. Chou $\$$. Effect of interstrain variation on diagnostic DNA amplification of the cytomegalovirus major immediate early region. J Clin Microbiol 1992;30:23072310.

59. Hendrix MGR, Beuken E, Slobbe RL, Bruggeman CA. Detection and sequence analysis of the major immediate early and PP150 gene of latent human cytomegalovirus in spleen, liver and kidney tissues of trauma victims. J. Med. Virol. $1996: 50: 193-197$.

60. Chou $\mathrm{S}$. Reactivation and recombination of multiple cytomegalovirus strains from individual organ donors. J Infect Dis 1989; 160: 11-15.

61. Shen C-Y. Chang S.F, Chao M-F. Huang E-S, Wu C-W. Identification of a serial change in recurrent cytomegalovirus strains in a healthy child by polymerase chain reaction. J Infect Dis 1993; 168: 252-253.

62. Spector SA, Hirata KK, Neuman TR. Identification of multiple cytomegalovirus strains in homosexual men with acquired immunodeficiency syndrome. I Infect Dis 1984; 150 : $953-956$.

63. Collier AC, Chandler SH, Handsfield HH, Corey L, McDougall JK. Identification of multiple strains of cytomegalovirus in homosexual men. J Infect Dis 1989; 159: $123-126$. 
Samenvatting 
Infecties met cytomegalovirus (CMV), een virus dat tot de familie van de herpesvirusen behoort, komen bil de mens vaak voor. Zo heeft 40 tot $90 \%$ van de volwassenen aantoonbare antistoffen tegen dit virus. Meestal verlopen deze infecties zonder merkbare gewolgen maar in sommige gevallen kan er een mononucleosis-achtig beeld onsitaan. Na de primaire infectie blift het virus levenslang in een sluimerende toestand binnen een gastheer aanwezig. Tijdens deze sluimerende toestand, latente infectie genaamd, vindt er geen virusreplicatie plaats en wordt hooguit een zeer klein deel van het virale genoom afgelezen. Waar, dat wil zeggen in weke cellen, het virus zich tijdens deze latente infectie bevindt, is nog steeds onduidelijk. Reactivatie vanuit deze latente toestand. waarbij weer actieve virusvermeerdering plaatsvindt, treedt vooral op bil personen met een gestoorde immuniteit, hetzij door de weerstandverlagende behandeling na orgaantransplantatie, of als gevolg van AIDS. CMV-reactivaties binnen deze patientengroepen veroorzaken vaak ernstige, en soms dodelijke, ziekteverschijnselen.

De gedachte dat er naast de bekende door CMV veroorzaakte ziekebeelden ook een verband tussen CMV en atherosclerose zou kunnen zijn, is gebaseerd op een aantal observaties. Zo veroorzaakt Marek's disease virus (MDV), een op CMV lijkend herpesvirus van vogels, bij kippen atherosclerose van de grote vaten. Met behulp van in situ DNA-hybridisatie is het mogelijk MDV-nucleinezuren in de atherosclerotische kippenvaatwand aan te tonen. Spoedig na deze ontdekking werd met in situ DNA-hybridisatie CMV aangetoond in vaatwanden van patienten die een reconstructie van de grote vatem wegens ernstige atherosclenose ondergingen. CMV kon echter ook worden aangetoond in de coronairvaten van jonge patienten zonder atherosclerotische degeneratie. Of CMW een rol speelt in de pathogenese van atherosclerose kan op basils van deze observaties niet worden geconcludeerd. Het is namelijk ook mogelijk dat de gladde spiercellen in de humane vaatwand een reservoir woor latent CMV zijn. Meer directe aanwijzingen dat CMV een rol zou kunnen spelen bij atherosclerose komen van andere observaties. Zo zal na een harttransplantatie een deel van de patienten een versnelde vorm van atherosclerose van de coronairvaten van het getransplanteerde hart doormaken. Deze versnelde vorm van atherosclerose treedt hoofdzakelijk op bij patienten die CMVseropositief zijn. Ook is er inmiddels een rattenmodel ontwikkeld waar atherosclerose ontstaat na een infectie met een ratten-cytomegalovirus. Binnen dit model bleek het mogelijk om met behulp van antivirale therapie het onstaan van atherosclerose na CMV infectio volledig te voorkomen.

Om nu te onderzoeken of er een verband bestaat tussen CMV en atherosclerose, of dat de humane vaatwand een reservoir voor virale latentie is, hebben we vaatwandbiopten bij twee verschillende patientengroepen genomen, en deze met moleculaire technieken, op de aanwezigheid van CMV-nucleinezuren onderzocht. De onderzoeksgroep bestond uit patienten die vanwege ernstige atherosclerotische afwijkingen (graad III) een electieve reconstructie van een groot vat ondergingen. Hierbij werd meestal een biopt van de Aorta abdominalis en soms van de Arteria femoralis genomen. Een controlegroep bestond uit gematchte patienten bij wie tijdens obductie was vastgesteld dat er vrijwel geen atherosclerose (maximaal graad 1) aanwezig was en bij wie een biopt van de Aorta abdominalis werd genomen. Met behulp van de polymerase kettingreactie (PCR) kon in 90\% valn de atherosclerotische vaatwanden CMV worden aangetoond, versus in $50 \%$ van de controle vaatwanden. De plaats waar de CMV-nucleinezuren zich bevonden, aangetoond met in situ DNA-hybridisatie, bleek in beide patientengroepen echter niet de degeneratieve vaatwand te zijn, maar juist dat deel van de vaatwand dat histologisch normaal was. Het CMV bleek in de gladde spiercellen aanwezig te zijn. Om te bekijken of CMV ook in andere arterien aanwezig is, werd een derde patientengroep verzameld waarbij tijdens obductie een biopt van alle ellastische arterien werd genomen. Analyse van deze biopten toonde aan dat CMV in de vaatwand van alle grote vaten 
aanwezig is, en tevens dat er geen enkele relatie met atherosclerotische verandering is. De hoeveetheid virus in al deze vaten was onafhankelik van de mate van atherosclero. se en was minder dan 2 virusceeltjes per 2500 cellen. Op basis van onze gegevens 15 het dus niet mogelijk een relatie tussen CMV en atherosclerose aan te tonen. De aanwezighelid van CMV in alle vaatwanden betekendt mogelikk wel dat de lang gezochte plaats voor dit virus tijdens zijn latente lase gevonden kan zijn.

Tijdens deze latente fase vindt er geen virusreplicatie plaats en wordt hooguit een zeer klein deel van het virale genoom afgelezen. Dat er in de vaatwanden geen virusreplicatie plaatsvindt hebben we kunnen afleiden uit het feit dat we ondanks tientallen pogingen geen prolifererend CMV hebben kunnen isoleren. Wel hebben we aannemelijk kunnen maken, zowel met de PCR als met dot blot DNA-hybridisatie, dat waarschijnlijk het hele virale genoom in de vaatwand aanwezig is, en dus dat de mogelijkheid tot reactivatie in leder geval genetisch bestaat. Dat er maar een klein deel van het genoom wordt afgelezen hebben we aangetoond met in situ DNA-hybridisatie. Alleen MRNA afgelezen van immediate early regio's van het genoom kon worden aangetoond terwijl mRNA afgelezen van andere regio's die met name tijdens de virusreplicatie actief zijn, niet kon worden aangetoond. Op basis van deze gegevens concluderen we dat de humane vaatwand een reservoir voor latent CMV is.

Omdat tijdens een acute CMV-infectie het virus in vrijwel alle organen aanwezig is dringt zich al snell de vraag op of het virus tijdens de latente fase ook in alle organen aantoonbaar is. Zowel met de PCR als met in situ DNA-hybridisatie was het inderdaad mogelik CMV aan te tonen in aan groot aantal organen en celtypes. Zo was het virus aantoonbaar in de gladde spiercellen van de vaatwand, hepatocyten, tubulaire en glomerulaire niercellen, cellen in de rode pulpa van de milt en in acinaire cellen van het pancreas. Om actieve virusproliferatie uit te sluiten zijn al deze biopten immunohistochemisch onderzocht op de aanwezigheid van virale eiwitten met behulp van monoclonale antilichamen, die gericht zijn tegen specifieke CMV-eiwitten. Deze werden echter nooit aangetoond. Op basis van deze gegevens concluderen we dat latent CMV in vele organen en celtypes aanwezig is.

Humane herpesvirussen vertonen veel overeenkomsten op DNA-niveau. Om aan te tonen dat HCMV en niet een ander herpesvirus in deze organen aanwezig was, werd het noodzakelijk de DNA-fragmenten die met de PCP uit de diverse organen geamplificeerd werden verder te analyseren. We hebben ervoor gekozen een sequentie-analyse van een groot deel van deze amplificaten uit te voeren. Het resultaat was dat er meer dan $95 \%$ homologie was met een HCMV prototypestam, aantonend dat inderdaad HCMV in de biopten aanwezig was. In een enkele patient werden consequent wee varianten van het virus aangetroffen, hetgeen suggereent dat een patient latent geinfecteerd kan zijn met meer dan eén stam.

in conclusie:

Hoewel op basis van andere studies een rol voor CMV in de pathogenese van atherosclerose tot de mogelijkheden behoort, hebben wij in ons systeem geen directe relatie tussen HCMV en atherosclerose kunnen aantonen. Wel hebben we aannemelijk kunnen maken dat in de latente fase HCMV in vele organen en celtypes, waaronder gladde spiercellen in de vaatwand, aanwezig is. 


\title{
Curriculum Vitae
}

\author{
Matheus Gerardus Ronald (Ron) Hendrix
}

28 november 1958 geboren te Maastricht

1978 Eindexamen Atheneum B, St. Maartenscollege te Maastricht

1979-1980 Vervulling militaire dienstplicht

1980-1984 Doctoraalstudie geneeskunde

1986 Doctoraal diploma geneeskunde (6 oktober)

1987

artsexamen, Rijksuniversiteit Limburg te Maastricht

1987-1991 Assistent in opleiding (AIO), medische microbiologie, Rijksuniversiteit Limburg te Maastricht o.l.v. Mw. Prof. Dr. C.A. Bruggeman

1991-1994 Opleiding medische microbiologie aan het Academisch Ziekenhuis Maastricht. Opleiders: Prof. Dr. C.P.A. van Boven en Dr. F. van Tiel Inschrijving specialisten register Arts-microbioloog Stichting Streeklaboratoria voor de volksgezondheid in Twente en de Gelderse Achterhoek te Enschede

1997 Benoeming tot medisch directeur/hoofd laboratorium Stichting Streeklaboratoria voor de volksgezondheid in Twente en de Gelderse Achterhoek te Enschede 


\section{Nawoord}

Het hier beschreven onderzoek is hoofdzakelijk uitgevoerd binnen de vakgroep medische microbiologie. Echter, ook de vakgroepen heelkunde, pathologie en celbiologie van de universiteit Maastricht en tevens de pathologen van hel De Wever ziekenhuis te Heerlen, de pathologen van Het Maaslandziekenthuis te Sittard en de stafleden van het centraal kinisch virologisch laboratorium van hel Academisch Zlekenhus Leiden hebben een wezenlijke bijdrage aan het tot stand komen van dit proefschrift geleverd.

Bimnen deze grote groep mensen is er een aantal die ik apart wil bedanken voor de belangrijke rol die ze hebben gespeeld.

Allereerst natuurlijk mijn promotor Cathrien Bruggeman. Beste Cathrien, ik bedank je natuurlijk voor de begeleiding tijdens mijn promotieonderzoek, maar vooral ook voor de periode ervoor (macrofagen) en erna (het maken van het boekje). Wat ik vooral waardeer is de grote mate van vrijheid die ik tijdens mijn onderzoek heb gekragen. Gedurende de lange tijd dat we elkaar inmiddels kennen heb ik in velerlei opzicht van je geleerd.

Prof. Dr. C.P.A. van Boven. Geachte Cees, zoals altijd op de achtergrond aanwezig maar met grote invloed. Mijn liefde voor de microbiologie heb ik ongetwijfeld van jou meegekregen.

Peter Dormans, dank je voor de (forse) hulp die jij me gaf tijdens mijn eerste stappen op het terrein van de praktische moleculaire microbiologie. Zonder deze hulp zou dit deel van de microbiolagie altijd boekenkennis zijn gebleven.

Prof. Dr. P.J.E.H.M. Kitslaar, wiens enthousiasme ervoor zorgde dat alle vaatoperaties onder mijn alandacht werden gebracht, zodat de patientengroepen konden worden samengesteld.

Marcel Salimans die ervoor zorgde dat ik vanaf het prille begin betrokken ben geraakt bij de PCR. Marcel, niet alleen jouw vakkennis maar ook je enthousiasme zijn zeer waardevol gebleken. Jouw bemoeienissen hadden zelfs een gigantische invloed op mijn privésituatie.

Math Daemen, jouw snelle bereidheid om in het onderzoek te participeren, maar ook de talrijke vruchtbare discussies zijn van groot belang gebleken.

Mariëtte Wagenaar, jouw constante doorvragen heeft me menigmaal tot herbezinning gedwongen en jouw inzet en enthousiasme waren verfrissend.

Rob Slobbe, ondanks het feit dat je in een relatief laat stadium bij mijn promotieonderzoek betrokken bent geraakt, kan ik alleen maar met genoegen aan jouw inbreng terugdenken. Niet alleen kon je een nieuwe wending in het onderzoek aanbrengen. maar kon je tevens veel moleculaire kennis overdragen.

Eric Beuken, jouw rustige en bekwame manier van werken kwam precies op een goed moment tijdens de afsluiting van de onderzoeksfase.

And last, but certainly not least. Wil Mullers. Wat je bijgedragen hebt kan ik niet precies benoemen, maar mijn vaste overtuiging is dat zonder jouw inbreng. je relativerende 
levenshouding en je inzet heel veel op heel veel gebieden niet goed was gegaan.

Naast dit persoonlijke dankwoord is het op zijn plaats de hele gemeenschap die een vakgroep toch eigenlijk is te bedanken voor hun bijdrage. Zonder mensen als Gert Grauls, Fia Claus, Yvette Kraat, Frans Stals, Maaike Persoons, Jan Jacobs, Frank van Tiel en Ellen Stobbering zou er geen onderzoeksklimaat zijn.

Ook wil ik mijn huidige collega's in Enschede en met name Wim Severin bedanken voor de tijd die zij mij gunden om in alle rust een aantal artikelen en mijn proefschrift af te kunnen schrijven.

En natuurlijk Esther.... 